Nutrition Research Reviews (2017), 30, 149-190

(C) The Authors 2017. This is an Open Access article, distributed under the terms of the Creative

Commons Attribution licence (http://creativecommons.org/licenses/by/4.0/), which permits

unrestricted re-use, distribution, and reproduction in any medium, provided the original work is properly cited.

\title{
Dietary fibre in Europe: current state of knowledge on definitions, sources, recommendations, intakes and relationships to health
}

\author{
Alison M. Stephen ${ }^{1}$, Martine M.-J. Champ ${ }^{2}$, Susan J. Cloran ${ }^{3}$, Mathilde Fleith ${ }^{4}$, Lilou van Lieshout ${ }^{5 *}$, \\ Heddie Mejborn ${ }^{6}$ and Victoria J. Burley ${ }^{7}$ \\ ${ }^{1}$ Department of Nutritional Sciences, Faculty of Health and Medical Sciences, University of Surrey, Guildford, Surrey GU2 7XH, UK \\ ${ }^{2}$ UMR Physiologie des Adaptations Nutritionnelles, INRA, CRNH Ouest, CHU, Hôtel-Dieu, HNB1, Place Alexis Ricordeau, 44093 \\ Nantes cedex 1, France \\ ${ }^{3}$ Kellogg Europe Trading Limited, Swords, Dublin, Republic of Ireland \\ ${ }^{4}$ Nestlé Research Centre, Vers-chez-les-Blanc, 1000 Lausanne 26, Switzerland \\ ${ }^{5}$ ILSI Europe, 83 Avenue E Mounier, Box 6, B-1200, Brussels, Belgium \\ ${ }^{6}$ Division of Risk Assessment and Nutrition, National Food Institute, Technical University of Denmark, Kgs, Lyngby, Denmark \\ ${ }^{7}$ Nutritional Epidemiology Group, School of Food Science and Nutrition, University of Leeds, Leeds LS2 9JT, UK
}

\section{Abstract}

Research into the analysis, physical properties and health effects of dietary fibre has continued steadily over the last 40-50 years. From the knowledge gained, countries have developed guidelines for their populations on the optimal amount of fibre to be consumed each day. Food composition tables from many countries now contain values for the dietary fibre content of foods, and, from these, combined with dietary surveys, population intakes have been determined. The present review assessed the uniformity of the analytical methods used, health claims permitted, recommendations and intakes, particularly from national surveys across Europe and around the world. It also assessed current knowledge on health effects of dietary fibre and related the impact of different fibre types on health. The overall intent was to be able to provide more detailed guidance on the types of fibre which should be consumed for good health, rather than simply a total intake figure, the current situation. Analysis of data indicated a fair degree of uniformity in the definition of dietary fibre, the method used for analysis, the recommended amount to be consumed and a growing literature on effects on digestive health and disease risk. However, national dietary survey data showed that intakes do not reach recommendations and very few countries provide guidance on the types of fibre that are preferable to achieve recommended intakes. Research gaps were identified and ideas suggested to provide information for more detailed advice to the public about specific food sources that should be consumed to achieve health benefits.

\section{Key words: Dietary fibre: Dietary recommendations: Dietary intakes: Health claims}

\section{Introduction}

There is now a long history of dietary fibre research around the world, including numerous studies showing relationships between fibre intake and health. Many countries carry out national surveys and most of these report total dietary fibre (TDF) intakes. From knowledge of the role of fibre in health and of intakes, recommendations have appeared since the 1970 s to increase the intake of dietary fibre in Western countries to ultimately improve the health of their populations. Many of these have included figures for the daily amount to be consumed and many have also suggested various high-fibre foods in their dietary guidelines. However, there have been few attempts to consolidate these recommendations across Europe. Moreover, there is little further guidance beyond a total quantity of fibre to be consumed such as to specify the types of fibre or the proportions of the different fibre-containing food sources to achieve an optimum intake. This is partly because of debates about how fibre should be subdivided into categories, since these have largely been unsatisfactory. Dietary guidance in recent years has also focused on topics other than fibre, such as efforts to address obesity and CVD and/or to achieve recommended intakes of nutrients like saturated fat, sugar and salt. The stimulus for this paper was to determine the current

Abbreviations: AACC, American Association for Clinical Chemistry; AFSSA, Agence Française de Sécurité Sanitaire des Aliments (French Agency for Food Safety); AOAC, Association of Official Analytical Chemists International; EC, European Commission; EFSA, European Food Safety Authority; EPIC, European Prospective Investigation into Cancer and Nutrition; EU, European Union; FSANZ, Food Standards Australia New Zealand; IoM, Institute of Medicine; MU, monomeric units; RO, resistant oligosaccharides; RR, relative risk; RS, resistant starch; SACN, Scientific Advisory Committee on Nutrition; TDF, total dietary fibre; WCRF, World Cancer Research Fund.

* Corresponding author: Ms Lilou van Lieshout, email publications@ilsieurope.be 
situation about how different countries in Europe describe dietary fibre, what they recommend in terms of dietary fibre to the public, and how intakes may vary both in total amount consumed and in the sources that provide fibre to the population. From this the intent was to be able to generate more detailed guidance for European countries about not only the quantity of fibre which should be consumed, but more specifically how this might be achieved in terms of foods and fibre sources that could contribute to intakes to achieve desirable health outcomes.

The purpose of this paper is therefore to:

(1) Describe the current status of dietary fibre definitions and potential subclassifications by which more detailed advice could be given to the public;

(2) Describe current dietary recommendations and guidelines in Europe which include fibre and to investigate how these vary both in recommended intake and in sources from which this should be obtained;

(3) Describe the permitted health claims in Europe and some selected countries, and how these vary in terminology and in the quantities of fibre required to satisfy the claim;

(4) Report the fibre intakes in different countries in Europe, both in terms of intakes of total fibre and of the sources that provide fibre;

(5) Assess how well intakes match recommendations;

(6) Summarise the latest literature on the relationship between fibre and the major diseases with which it has been associated, particularly where subdivisions of fibre or sources of fibre have been described as being protective. The intent was to determine those conditions for which there is sufficient evidence to able statements to be made to the public with some confidence;

(7) Draw these various threads together to suggest a common recommended intake for fibre in Europe and to attempt to suggest how this fibre should be derived, such as in the proportion of intakes which should come from various food groups.

In outlining these various aspects of dietary fibre recommendations, it is also intended to identify gaps in knowledge about intakes and types of fibre and sources and in the potential relationships between fibre intakes and disease outcomes. The goal of this paper was not to provide an overview of every aspect of dietary fibre in terms of its chemistry, physiology or health effects but to consider where existing knowledge is being applied at the population level - thus the accepted methods for analysis, not all methods available, intakes in national surveys of the population, not every study published, permitted health claims, where enough evidence exists to enable manufacturers to make a statement to the public, not on health effects where there is insufficient evidence to be able to draw conclusions and provide guidance to the public at large. Indeed, it is essentially a review with a public health approach. For aspects of research on dietary fibre not covered in this review, such as bioavailability, interaction with minerals or appropriateness of different fibre types for specific health conditions, readers are encouraged to seek out the appropriate literature.
Definitions of dietary fibre, classification of fibre and fibre sources, conditions for nutrition claims and analytical methods (Tables 1-7, Figs 1 and 2)

\section{Methods used to compile tables}

For definitions, classification, structures, sources and analytical methods for dietary fibre, a search was made mostly through Google and PubMed. Search terms were: dietary fibre/fiber, definition, classification, sources, structure, composition, analysis, analytical method. Specific key words were then used, such as bulking effect, viscosity, fermentation or polysaccharide and oligosaccharide names. DF content used to build Table 6 was extracted mainly from a food composition table ${ }^{(1)}$.

\section{Results: definitions}

Over the years, the definition of dietary fibre has been subject to much discussion. The most recent definitions, from about 2008 (for example, Codex Alimentarius Alinorm) ${ }^{(2)}$, have general global agreement. Dietary fibre is made up of carbohydrate polymers with three or more monomeric units (MU), which are neither digested nor absorbed in the human intestine and includes: (1) NSP from fruits, vegetables, cereals and tubers whether intrinsic or extracted, chemically, physically and/or enzymically modified or synthetic ( $M U \geq 10$ ); (2) resistant (non-digestible) oligosaccharides (RO) (MU 3-9); and (3) resistant starch (RS) (MU $\geq 10$ ). When extracted, chemically, physically and/or enzymically modified or synthetic, generally accepted scientific evidence of benefits for health must be demonstrated to consider the polymer as dietary fibre. Most definitions also include 'associated substances', which are non-carbohydrate such as lignin and substances which are present in cell walls linked to polysaccharides and quantified as dietary fibre by the accepted analytical methods (Tables 1 and 2). The main differences between definitions are related to:

(1) 'Associated substances' (lignin, mainly) which are or are not explicitly included in dietary fibre definition.

(2) The minimum number of carbohydrate monosaccharide units to be included; the European Union (EU) definition prescribes a minimum MU number (sometimes called 'degree of polymerisation') of 3, while Codex Alimentarius prescribes a minimum of 10 but leaves to the local authority the decision on whether or not to include carbohydrates with an MU number of 3 to 9. Since many countries outside the EU have no local regulatory definition, the default is to adopt the Codex definition of MU number $\geq 10$ (Table 2). As a consequence, in these countries, RO are or are not considered as dietary fibre, independently from the demonstration of a beneficial effect.

(3) The requirement, mainly for extracted, isolated, modified or synthetic carbohydrate polymers, that they have been shown to have a benefit to health. Most authorities throughout the world have a (non-exclusive) list for health benefits related to dietary fibre. This list is included in the definition as, for example from Agence Française de Sécurité Sanitaire des Aliments (French Agency for Food Safety) AFSSA (2002) ${ }^{(3)}$ (now Agence Nationale Française de Sécurité Sanitaire de l'Alimentation, de l'Environnement et du Travail; ANSES) in France, American Association for 
Table 1. Principal definitions of dietary fibre

\begin{tabular}{|c|c|c|c|}
\hline Organisation & Definition & $\begin{array}{l}\text { Components included in definition } \\
\text { MU to qualify as fibre }\end{array}$ & Reference \\
\hline Codex Alimentarius & $\begin{array}{l}\text { 'Dietary fiber is defined as carbohydrate polymers }{ }^{\mathrm{a}} \text { with ten or more monomeric units }{ }^{\mathrm{b}} \text {, which are not } \\
\text { hydrolyzed by the endogenous enzymes in the small intestine of humans and belong to the following } \\
\text { categories: } \\
\text { - Edible carbohydrate polymers naturally occurring in the food as consumed, } \\
\text { - Carbohydrate polymers, which have been obtained from food raw material by physical, enzymatic or } \\
\text { chemical means and which have been shown to have a physiological effect of benefit to health as } \\
\text { demonstrated by generally accepted scientific evidence to competent authorities, } \\
\text { - Synthetic carbohydrate polymers which have been shown to have a physiological effect of benefit to health } \\
\text { as demonstrated by generally accepted scientific evidence to competent authorities.' } \\
\text { Footnotes (ALINORM } 10 / 33 / 26,10 / 33 / R E P) \\
\text { a. 'When derived from a plant origin, dietary fiber may include fractions of lignin and/or other compounds } \\
\text { associated with polysaccharides in the plant cell walls. These compounds also may be measured by } \\
\text { certain analytical method(s) for dietary fiber. However, such compounds are not included in the definition } \\
\text { of dietary fiber if extracted and re-introduced into a food. } \\
\text { b. Decision on whether to include carbohydrates of } 3 \text { to } 9 \text { monomeric units should be left up to national } \\
\text { authorities.' }\end{array}$ & $\begin{array}{l}\mathrm{DF}=\mathrm{NSP}+\mathrm{RS}+\mathrm{RO} \text { (when MU number } \\
3-10 \text { included in the definition) + lignin } \\
\text { and other compounds (when } \\
\text { associated with polysaccharides in } \\
\text { the plant cell wall) } \\
\mathrm{MU} \geq 10 \text { (general definition) } \\
\mathrm{MU} \geq 3 \text { (upon local approval) }\end{array}$ & $\begin{array}{l}\text { ALINORM 09/32/REP(2) } \\
\text { ALINORM 10/33/26, 10/ } \\
\text { 33/REP } \\
\end{array}$ \\
\hline European Community & $\begin{array}{l}\text { 'Fibre' means carbohydrate polymers with three or more monomeric units, which are neither digested nor } \\
\text { absorbed in the human small intestine and belong to the following categories: } \\
\text { - Edible carbohydrate polymers naturally occurring in the food as consumed; } \\
\text { - Edible carbohydrate polymers which have been obtained from food raw material by physical, enzymatic or } \\
\text { chemical means and which have a beneficial physiological effect demonstrated by generally accepted scientific } \\
\text { evidence; } \\
\text { - Edible synthetic carbohydrate polymers which have a beneficial physiological effect demonstrated by generally } \\
\text { accepted scientific evidence.' } \\
\text { It is said in Article (5) that 'Fibre... has one or more beneficial physiological effects such as: decrease } \\
\text { intestinal transit time, increase stool bulk, is fermentable by colonic microflora, reduce blood total } \\
\text { cholesterol levels, reduce post-prandial blood glucose, or reduce blood insulin levels' and that the } \\
\text { definition of fibre should include carbohydrate polymers with one or more beneficial physiological effects'. }\end{array}$ & $\begin{array}{l}\mathrm{DF}=\mathrm{NSP}+\mathrm{RS}+\mathrm{RO} \\
\mathrm{MU} \geq 3\end{array}$ & Directive $2008 / 100 / \mathrm{EC}^{(89)}$ \\
\hline $\begin{array}{l}\text { European Food } \\
\text { Safety Agency } \\
\text { (EFSA) }\end{array}$ & $\begin{array}{l}\text { Dietary fibre is defined as 'non-digestible carbohydrates plus lignin'. EFSA Panel considers that the main types } \\
\text { of DF are: non-starch polysaccharides (NSP) (cellulose, hemicelluloses, pectins, hydrocolloids (i.e. gums, } \\
\text { mucilages, } \beta \text {-glucans)), resistant oligosaccharides (fructo-oligosaccharides (FOS), galacto- } \\
\text { oligosaccharides (GOS), other resistant oligosaccharides), resistant starch (consisting of physically } \\
\text { enclosed starch, some types of raw starch granules, retrograded amylose, chemically and/or physically } \\
\text { modified starches), and lignin associated with the dietary fibre polysaccharides.' }\end{array}$ & $\begin{array}{l}\mathrm{DF}=\mathrm{NSP}+\mathrm{RS}+\mathrm{RO}+\text { lignin (when } \\
\text { associated to } \mathrm{DF} \text { polysaccharides) } \\
\mathrm{MU} \geq 3\end{array}$ & EFSA, $2010^{(86)}$ \\
\hline $\begin{array}{l}\text { Agence Française de } \\
\text { Sécurité Sanitaire } \\
\text { des Aliments } \\
\text { (AFSSA, France) }\end{array}$ & $\begin{array}{l}\text { According to the French authorities, dietary fibres are dietary constituents not digested by the enzymes of the } \\
\text { gastrointestinal tract, mainly plant-derived constituents, for example, cellulose, hemicellulose, lignins, gums, } \\
\text { alginates, carragenans, resistant starch. Minor dietary components such as oligosaccharides (fructo- } \\
\text { oligosaccharides, a-galactosides, lactulose), constituents produced by micro-organisms (xanthanes), } \\
\text { constituents of crustaceans (for example, chitine, chitosane) are also included. This definition has been } \\
\text { used as a starting point by the Codex Alimentarius to elaborate its own definition. } \\
\text { The definition adopted by the Specialist Expert Committee on Human Nutrition of AFSSA in } 2002 \text { was the } \\
\text { following: } \\
\text { 'Dietary fibres are: } \\
\text { - Carbohydrate polymers (DP } \geq 3 \text { ) from plant origin, associated or not in the plant to lignin or non-carbohydrate } \\
\text { polymers (polyphenols, wax, saponins, cutin, phytates, phytosterols). } \\
\text { OR } \\
\text { - Transformed (physically, enzymatically or chemically) or synthetic carbohydrate polymers (DP } \geq 3 \text { ) mentioned in } \\
\text { a positive list which will be implemented by AFSSA with new polymers when approved by the Committee. } \\
\text { MOREOVER, dietary fibres are not digested, nor absorbed in the small intestine. They present one or more of the } \\
\text { following properties: } \\
\text { - Increase of stool production, } \\
\text { - Stimulation of colonic fermentation, } \\
\text { - Decrease of fasting cholesterolemia, } \\
\text { - Decrease of post-prandial glycaemia and insulinaemia.' }\end{array}$ & $\begin{array}{l}\mathrm{DF}=\mathrm{NSP}+\mathrm{RS}+\mathrm{RO}^{*}+\text { lignin and other } \\
\text { minor components (when associated } \\
\text { to } \mathrm{DF} \text { polysaccharides). } \\
\mathrm{MU} \geq 3 \\
{ }^{*} \mathrm{RO} \text { included in } \mathrm{DF} \text { definition have to } \\
\text { been derived (hydrolysis or synthesis) } \\
\text { from plant polysaccharides or sugars }\end{array}$ & $\begin{array}{l}\text { Martin, } 2001^{(90)} \\
\text { AFSSA, } 2002^{(3)}\end{array}$ \\
\hline
\end{tabular}


Components included in definition $\mathrm{MU}$ to qualify as fibre

$\mathrm{DF}=\mathrm{NSP}+\mathrm{RS}+\mathrm{RO}+$ lignin and other minor components (when associated to DF polysaccharides of plants)

American Association 'Dietary fiber is the edible parts of plants or analogous carbohydrates that are resistant to digestion and of Cereal Chemists absorption in the human small intestine with complete or partial fermentation in the large intestine. Dietary (AACC)

Institute of Medicine (USA) promes beneflcial physiolo or blood glucose attenuation.

Dietary fiber consists of non-digestible carbohydrates and lignin that are intrinsic and intact in plants. Added fiber consists of isolated, non-digestible carbohydrates that have beneficial physiological effects in humans. Total fiber is the sum of dietary fiber and added fiber.

is indeation are concentrations and/or improved laxation'.

Englyst et al. (UK)

'The Englyst procedure measures dietary fiber as NSP (non-starch polysaccharides), i.e., non-a-glucan polysaccharides in plant foods.'

Health Canada

'Dietary fiber consists of:

1) Carbohydrates with a DP of 3 or more that naturally occur in foods of plant origin and that are not digested and absorbed by the small intestine; and

Accepted novel fibres.

Novel fibres are ingredients manufactured to be sources of DF and consist of carbohydrates with a DP of 3 or more that are not digested and absorbed by the small intestine. They are synthetically produced or are to modify the properties of the fibre coven history to modify the properties of the wibre contained therein. Accepted

* Later on in the document it is indicated that the effects attributable to dietary fibre (not exclusive as other effects may be recognised by Health Canada as science evolves) are the following:

Dietary fibre

- Improves laxation or regularity by increasing stool bulk;

- Reduces blood total and/or low-density lipoprotein cholesterol levels;

- Reduces post-prandial blood glucose and/or insulin levels;

- Provides energy-yielding metabolites through colonic fermentation

Food Standards Dietary fibre means that fraction of the edible part of plants or their extracts, or synthetic analogues that Australia and New a) are resistant to the digestion and absorption in the small intestine, usually with complete or partia Zealand (FSANZ)

fermentation in the large intestine; and

b) promote one or more of the following beneficial physiological effects -

(i) laxation;

(ii) reduction in blood cholesterol

(iii) modulation of blood glucose;
and includes polysaccharides, oligosaccharides (degree of polymerisation $>2$ ) and lignins

Food and Drug Administration

proposal (March

dietary fibers that are added to foods that FDA (see section I.D.5.a.i.) that "only alows for the declara

dietary fibers that are added to "oods that FDA has determined to have a physiological effect that is

1. Soluble and insoluble non-digestible carbohydrates (NDC) (with 3 or more monomeric units) and lignin that are intrinsic and intact in plants, and

2014)

2. Isolated and synthetic NDC $(\geq 3$ monomeric units). that FDA has granted be included in the definition of

$\mathrm{DF}=\mathrm{NDC}$ (intrinsic and intact from

plants) + lignin (when associated to

DF polysaccharides of plants) $=$ NSP

(intrinsic and intact from plants) + RS (intrinsic and intact from

plants) + lignin (when associated to

plants) + lignin (when associated tc
DF polysaccharides of plants).

Added fibre $=$ isolated NDC

Total fibre $=\mathrm{DF}+$ added fibre

$\mathrm{MU} \geq 3$

$\mathrm{DF}=\mathrm{NSP}=$ polysaccharides - starch (including RS)

$\mathrm{DF}=\mathrm{NSP}+\mathrm{RS}+\mathrm{RO}$ dietary fiber, in response to a petition submitted to FDA demonstrating that such carbohydrates have a physiological effect beneficial to human health. According to FDA, there are currently only two isolated non-digestible carbohydrates, $\beta$-glucan and barley $\beta$-fiber, that would meet the proposed definition of DF.

3. Carbohydrates (with three or more monomeric units) that are the subject of an authorised health claim. effect that is beneficial to human health
end

Englyst et al. 1987

ealth Canada, $2012^{(6)}$

loM, $2005^{(7)}$

$\mathrm{DF}=\mathrm{NSP}+\mathrm{RS}+\mathrm{RO}(\mathrm{DP}>2)$ and lignin $\mathrm{FSANZ}, 2013^{(5)}$ $\mathrm{MU} \geq 3$

MU, monomeric units; DF, dietary fibre; RS, resistant starch; RO, resistant oligosaccharides; DP, degree of polymerisation; NDC, non-digestible carbohydrates. 
Table 2. International acceptance of CODEX definition (or very similar regulations) and inclusion of non-digestible oligosaccharides*

\begin{tabular}{|c|c|c|c|}
\hline $\begin{array}{l}\text { Accepting all MU number }>3 \\
\text { and CODEX definition }\end{array}$ & $\begin{array}{l}\text { Rejecting MU number }<10 \\
\text { (accepting CODEX definition) }\end{array}$ & Undecided with proposals & Undefined status \\
\hline $\begin{array}{l}\text { EU } \\
\text { Australia and New Zealand } \\
\text { Chile for labelling } \\
\text { China } \\
\text { Japan } \\
\text { Korea }\end{array}$ & $\begin{array}{l}\text { Chile for health claims } \\
\text { South Africa }\end{array}$ & $\begin{array}{l}\text { Canada: proposing to go to }>3 \text { and } \\
\text { CODEX definition } \\
\text { USA: still focused on the IOM report and } \\
\text { what action to take. IOM DP }>3\end{array}$ & $\begin{array}{l}\text { African countries other than South Africa } \\
\text { Brazil } \\
\text { India } \\
\text { Middle East } \\
\text { Russia } \\
\text { Switzerland } \\
\text { Other South American countries }\end{array}$ \\
\hline
\end{tabular}

MU, monomeric units; EU, European Union; IOM, Institute of Medicine; DP, degree of polymerisation.

* With MU number 3-10 as dietary fibre.

Clinical Chemistry (AACC) in the USA $(2001)^{(4)}$ or Food Standards Australia New Zealand (FSANZ) (2013, in Australia $^{(5)}$ and New Zealand) or mentioned somewhere else in the text of the definition document (Codex Alimentarius $(2009)^{(2)}$, Health Canada $(2012)^{(6)}$, Institute of Medicine (IoM) (2005) ${ }^{(7)}$ in the USA). The health benefits associated with the definition are related to:

(3a) Colonic function: 'increase of stool production' or 'stimulation of colonic fermentation' for AFSSA, 'beneficial effect on/improved laxation' for AACC, FSANZ and IOM, 'improves laxation or regularity by increasing stool bulk' and 'provides energy-yielding metabolites through colonic fermentation' for Health Canada $(2012)^{(6)}$, 'decrease intestinal transit time, increase stool bulk' for the European Commission $(\mathrm{EC})^{(8)}$;

(3b) Blood cholesterol: 'decrease of fasting cholesterolaemia', 'blood cholesterol attenuation' or 'reduction in blood cholesterol', for AFSSA, EC, AACC and IoM and FSANZ, 'reduces blood total and/or low-density lipoprotein (LDL) cholesterol levels' for Health Canada $(2012)^{(6)}$

(3c) Blood glucose: 'reduces/decreases/attenuation of post-prandial blood glucose/glycaemia and/or insulin levels/insulinaemia', 'blood glucose attenuation' and 'modulation of blood glucose' (for Health Canada, AFSSA, EC and IOM, AACC and FSANZ).

\section{Classification of fibre, fibre sources and conditions for nutrition claims}

Table 3 presents the classification of dietary fibre according to chemical structure, the main sources of the various fibre types, as well as physicochemical properties, such as water solubility and viscosity and physiological properties, such as fermentability.

Dietary fibre is often subdivided into oligosaccharides (MU number 3-9) (RO) and polysaccharides, including NSP and RS, with a minimum MU number of $10^{(9)}$, provided in an overview in Fig. 1. Dietary fibre also comprises 'associated substances'.

While several of the analytical methods quantify soluble and insoluble dietary fibre separately (for example, McCleary et $a{ }^{\left({ }^{(10)}\right)}$, there are very few publications which provide a classification of the main dietary fibre sources using this subdivision. RS and 'associated substances' are mostly insoluble in water, RO are mostly soluble whereas the solubility of NSP depends on the MU number, the MU composition and the linkages which are involved in the polymer. When soluble, some NSP, such as high-molecular-weight guar gum or $\beta$-glucans, certain pectins or psyllium, are also viscous or gel-forming in the intestinal tract, and this property may influence glucose and lipid metabolism. The scientific opinions of the European Food Safety Authority (EFSA) in 2010 on dietary reference values for carbohydrates and dietary fibre ${ }^{(11)}$ and on the substantiation of health claims related to dietary fibre ${ }^{(12)}$ mentioned that the terms "soluble" and "insoluble" have been used in the literature to classify dietary fibre in an attempt to link different physicalchemical properties of fibre components to different physiological effects. However, the classification by water solubility is method-dependent, and does not always predict physiological effects, although in most cases soluble fibre types are fermented more quickly than insoluble types ${ }^{,(13)}$. Aqueous solubility is not directly related either to fermentability or to the profile of SCFA produced through fermentation, another characteristic of interest regarding effects of dietary fibre on colon cancer prevention. The bulking effect of dietary fibre is an important property when considering impact on constipation and more generally on faecal bulk. In order to have a bulking effect of any consequence, fibre must be mainly insoluble, reach the distal colon (i.e. be at least partially resistant to fermentation and/or slowly fermented in the colon) and have a significant waterholding capacity. Faecal-bulking capacity of various dietary fibre sources has been measured and/or discussed by several authors $^{(14-18)}$ and it was concluded that there are few dietary fibre types which meet all these criteria. Monro ${ }^{(16)}$ has developed a table of faecal bulking index of sixty-six foods along with their TDF content, but these were based on measurements in rats so may not be directly applicable to humans.

It might be useful to propose a classification of dietary fibre materials according to their main characteristics: (1) viscosity in solution and/or in the digestive tract; (2) fermentability in the colon (possibly including the fermentation pattern: rate of fermentation and SCFA profile); and (3) bulking effect in the colon. However, data on all these characteristics are not yet available for many dietary fibre types and sources (Table 3), and often the fibres themselves may be poorly specified (for example, with regard to molecular weight or subunit ratios) which has also been a key issue limiting health claims for fibres in Europe. Moreover, a classification according to these 
Table 3. Classification of dietary fibre according to main chemical components, main food sources, and main properties*

\begin{tabular}{|c|c|c|c|c|c|c|}
\hline Subgroup & $\begin{array}{l}\text { Class of poly } / \\
\text { oligosaccharides }\end{array}$ & Molecules & Main sources & Water solubility & Viscosity & Fermentability \\
\hline \multirow[t]{13}{*}{$N S P(M U \geq 10) \dagger$} & \multirow{7}{*}{$\begin{array}{l}\text { Cellulose } \\
\text { Hemicelluloses } \\
\text { (heteroxylans) }\end{array}$} & $\beta(1-4)$ linked glucose units & Outer layers of cereals, pulses & - & & + \\
\hline & & $\begin{array}{l}\mathrm{AX}((1 \rightarrow 4)-\beta \text {-D-xylan backbone with single } \\
\quad \mathrm{a}-\mathrm{L} \text {-arabinofuranose units as side branches })(\mathrm{A}: \mathrm{X} \text { ratio }>0.4)\end{array}$ & $\begin{array}{l}\text { Starchy endosperm and aleurone } \\
\text { layer of cereal grains (i.e. } \\
\text { wheat, rye, barley) }\end{array}$ & $\begin{array}{l}++ \text { or }- \\
\text { Varies with sources; } \\
25-30 \% \text { of } A X \text { are } \\
\text { water soluble and } \\
\text { highly viscous }\end{array}$ & $\begin{array}{l}++ \text { or }- \\
\text { Varies with source; } \\
25-30 \% \text { of } A X \\
\text { are water } \\
\text { soluble and } \\
\text { highly viscous }\end{array}$ & 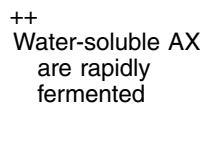 \\
\hline & & $\begin{array}{l}\text { Glucuronoxylans and glucurono-arabinoxylans }((1 \rightarrow 4) \text { - } \\
\beta \text {-D-xylan backbone with glucuronic acid units and/or } \\
\text { a-L-arabinofuranose units as substituents }(A: X<0 \cdot 2))\end{array}$ & $\begin{array}{l}\text { Fruits and vegetable cell walls, } \\
\text { outer tissues of cereal grains }\end{array}$ & $\begin{array}{l}\text { Become partially } \\
\text { soluble after } \\
\text { extraction }\end{array}$ & - & + \\
\hline & & $\begin{array}{l}\text { Heteroxylans }(1 \rightarrow 4)-\beta \text {-o-xylan backbone highly substituted by single } \\
\text { arabinose units, single glucuronic acid unit, and more complex } \\
\text { short side chain containing arabinose, xylose and galactose }\end{array}$ & $\begin{array}{l}\text { Outer layers of cereal grains } \\
\text { (wheat, barley, maize, rye, rice, } \\
\text { sorghum) } \\
\text { Starchy endosperm of some } \\
\text { cereal grains (maize, sorghum) }\end{array}$ & $\begin{array}{l}\text { Become fully soluble } \\
\text { after alkaline } \\
\text { extraction }\end{array}$ & - & -+ when extracted \\
\hline & & $\begin{array}{l}\text { Heteroxylans with } 1: 4 \text { and } 1: 3 \text { linkages as the backbone. Short } \\
\text { side chains contain arabinose, galactose and rhamnose are } \\
\text { also present }\end{array}$ & $\begin{array}{l}\text { Psyllium (Plantago ovata, indica, } \\
\text { psyllium, asiatica or major) } \\
\text { seed husk }\end{array}$ & ++ & +++ & + \\
\hline & & $\begin{array}{l}(1 \rightarrow 3,1 \rightarrow 4)-\beta \text {-D-glucans (mixed-linked } \beta \text {-glucans); the }(1,3) \\
\text { linkages lead to a structure of predominantly } \beta \text {-(1,3) linked } \\
\text { cellotriosyl (DP3) and cellotetraosyl units (DP4) backbone } \\
\text { side-branched by a-D--xylopyranosyl units, } \beta \text {--- } \\
\text { galactopyranosyl and a-L-fucopyranosyl units }\end{array}$ & $\begin{array}{l}\text { Cereal grains (very abundant in } \\
\text { oat and barley endosperm) }\end{array}$ & $\begin{array}{l}+ \\
\text { Solubility depends on } \\
\text { DP3-DP4 block } \\
\text { distribution and on } \\
\text { extraction } \\
\text { temperature }\end{array}$ & ${ }^{++}$ & ++ \\
\hline & & $\begin{array}{l}\text { Xyloglucan }((1 \rightarrow 4)-\beta-\mathrm{D}-\text { glucan backbone side-branched by } \\
\text { a-D-xylopyranosyl units or a-D-xylopyranosyl and } \\
\beta \text {-D-galactopyranosyl or a-D-xylopyranosyl, } \beta-\mathrm{D}-\text {-galactopyranosyl } \\
\text { a-D-xylopyranosyl and a---fucopyranosyl units or } \\
\text { a-L-arabinofurasonyl units. Galactose units can be acetylated }\end{array}$ & $\begin{array}{l}\text { Grain legumes, seeds from } \\
\text { nasturtium and tamarind tree, } \\
\text { fruits and vegetables cell walls }\end{array}$ & ++ & $\begin{array}{l}\text { In presence of } 40- \\
\quad 65 \% \text { sugar or by } \\
\text { adding alcohol }\end{array}$ & + or ++ \\
\hline & \multirow[t]{4}{*}{$\begin{array}{l}\text { Mannans and } \\
\text { heteromannans }\end{array}$} & $\begin{array}{l}\text { Mannans (linear) }(\beta-1,4 \text {-linked } \beta \text {-D-mannopyranosyl residues } \\
( \pm<5 \% \text { galactose })\end{array}$ & $\begin{array}{l}\text { Ivory nut, date, green coffee bean } \\
\text { seeds, endosperm of Palmæ, } \\
\text { aloe vera }\end{array}$ & - & - & ++ \\
\hline & & $\begin{array}{l}\text { Galactomannans: mannans substituted with side chains of } \\
a-1,6 \text {-linked galactose residues (i.e. guar gum) }\end{array}$ & $\begin{array}{l}\text { Grain legumes (endosperm), } \\
\text { species of Annonaceæ, } \\
\text { Convolvulaceæ, Ebenaceæ, } \\
\text { Loganiacæ, Palmæ } \\
\text { Guar gum }\end{array}$ & $\begin{array}{l}+++ \\
\text { Influenced by chain } \\
\text { length/mannose: } \\
\text { galactose ratio }\end{array}$ & $\begin{array}{l}+++ \\
\text { Influenced by } \\
\text { chain length/ } \\
\text { mannose: } \\
\text { galactose ratio }\end{array}$ & ++ \\
\hline & & $\begin{array}{l}\text { Glucomannans: } \beta \text { - }(1 \rightarrow 4) \text {-linked linear mannan chain with } \\
\text { interspersed glucose residues in the main chain and are often } \\
\text { acetylated }\end{array}$ & $\begin{array}{l}\text { Lilies, irises plant and fungal cell } \\
\text { walls, associated to cellulose } \\
\text { Konjac mannan (from } \\
\text { Amorphophallus konyac) }\end{array}$ & $\stackrel{+++}{\text { Konjac mannan }}$ & $\begin{array}{l}+++ \\
\text { Konjac mannan }\end{array}$ & + or ++ \\
\hline & & $\begin{array}{l}\text { Galactoglucomannans: glucomannans with D-galactose } \\
\text { residues attached to both D-glucosyl and D-mannosyl units as } \\
\text { a-1,6-linked terminal branches }\end{array}$ & Norway spruce wood pulp & ? & ? & ? \\
\hline & Pectin & 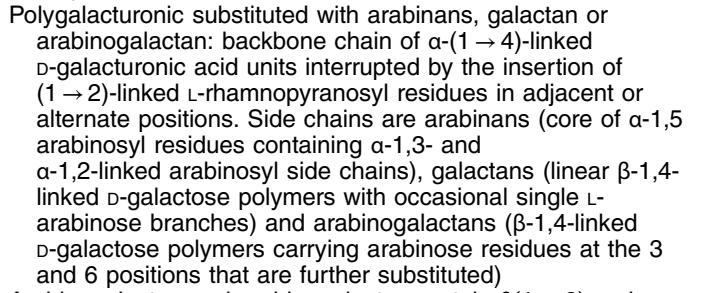 & $\begin{array}{l}\text { Fruit (apple, citrus etc) peel } \\
\text { (highest concentration in } \\
\text { middle lamella) } \\
\text { Beetroot, rice endosperm, grain } \\
\text { legumes, rapeseed cotyledon } \\
\text { Traces in maize bran and wheat }\end{array}$ & ++ & $\begin{array}{l}++ \\
\text { With sugars and } \\
\quad \text { acid }\end{array}$ & ++ \\
\hline & $\begin{array}{l}\text { Other hydrocolloids } \\
\text { (including gums and } \\
\text { mucilages) }\end{array}$ & $\begin{array}{l}\text { Arabinogalactan and arabinogalactan protein } \beta(1 \rightarrow 3) \text { and } \\
\beta(\rightarrow 6) \text { galactan backbone mainly substituted by single } \\
\text { arabinose units and sometimes by glucuronic acid units } \\
\text { (arabic gum). The highly branched polysaccharide structure is } \\
\text { generally covalently associated with a peptidic moiety }(10 \% \\
\text { (w/w) of the polymer) }\end{array}$ & $\begin{array}{l}\text { Fruit and vegetables, cereal } \\
\text { grains, plant exudates }\end{array}$ & +++ & $\begin{array}{l}+ \text { (due to branched } \\
\text { compact } \\
\text { structure) }\end{array}$ & + \\
\hline
\end{tabular}




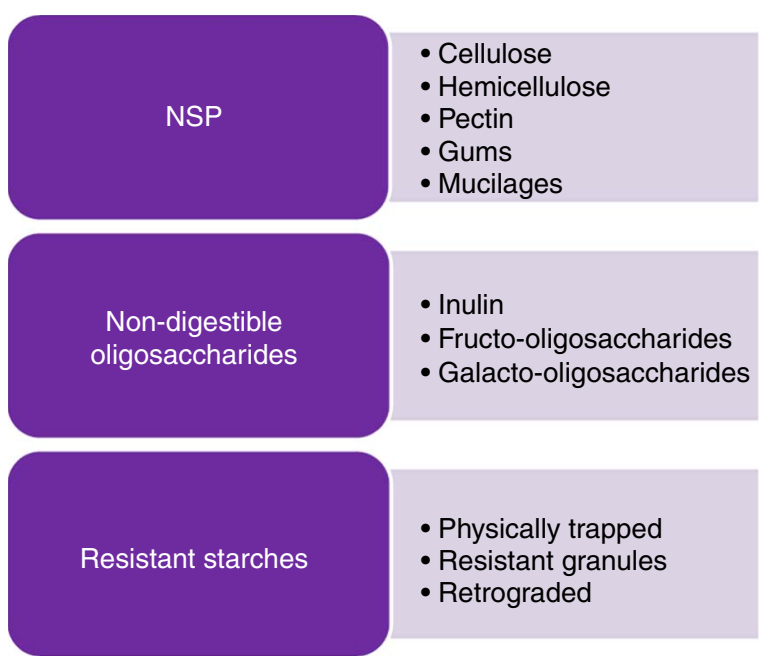

Fig. 1. Some examples of potential fibre sources.

physicochemical properties will be difficult to consider in dietary fibre analysis.

However, a few broad statements can be made:

(1) $\mathrm{RO}$ are largely soluble (but not viscous) and highly fermentable in the colon;

(2) Amongst NSP, cellulose and arabinoxylans from hulls and brans are largely insoluble and poorly fermentable;

(3) Amongst NSP, minimally hydrolysed hydrocolloids (i.e. pectins and gums) are viscous or gel-forming;

(4) Psyllium/ispaghula, carboxymethylcellulose and coarse bran have a high bulking effect ${ }^{(18)}$.

Table 4 gives information on the main dietary fibre components found in different food categories. The fibre content of the food as eaten depends on the fibre DM and on the concentration in hulls or bran which are highly concentrated in dietary fibre.

Some types of dietary fibre are not present in all food categories. Such is the case of RS which is clearly only present in starchy foods (cereals, tubers, non-mature fruits (mostly in green banana)), $\beta$-glucans which are mostly present in some cereals and legumes, and pectic substances which are present mainly in fruits and some vegetables.

Extracted, isolated, modified or synthetic fibre sources with specific properties are also available for enrichment of foods or for providing techno-functional properties to food. These are considered 'additives' and are mostly hydrocolloids such as pectin and gums. All the commercially available non-digestible carbohydrates of $\mathrm{MU} \geq 3$ do not appear in the positive lists of 'dietary fibre' set up by national or international authorities (Table 5). These lists are as yet incomplete and can be updated when adequate scientific information on beneficial health effects is available. It is interesting to note that in the scientific opinion on the substantiation of health claims relating to xanthan gum ${ }^{(19)}$ and 'changes in bowel function', xanthan gum is not presented as dietary fibre. This is probably because of the definition of dietary fibre adopted by EFSA, which states that carbohydrate polymers obtained by physical, enzymic or

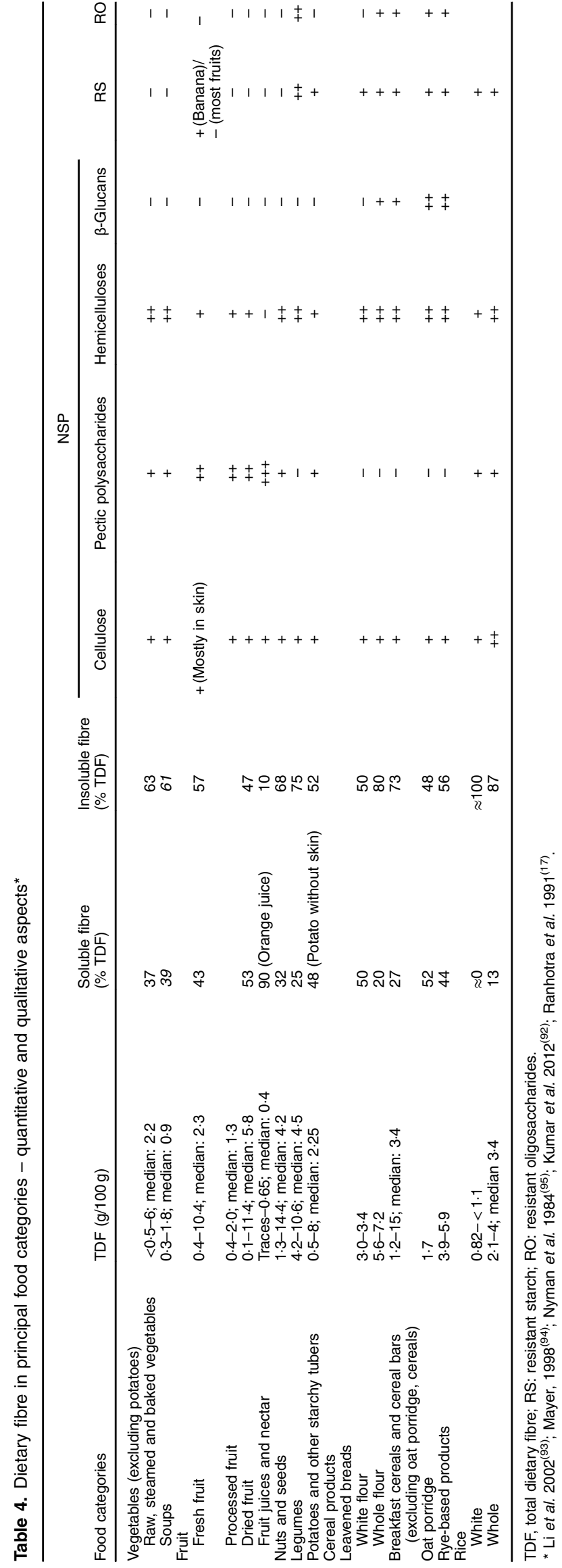


Table 5. Extracted and synthetic fibre sources recognised as 'dietary fibre' in Europe

\begin{tabular}{lll}
\hline Authority (country) & Fibre & Reference \\
\hline ANSES (France) & Fructo-oligosaccharides (synthetic polymer from sucrose) & AFSSA (2002) \\
& and oligofructose (derived from inulin) \\
& Psyllium husk & AFSSA (2008) \\
& Resistant starch RS3 & AFSSA $(2003,2005)^{(97,98)}$ \\
& Guar gum & AFSSA $(2002,2009)^{(99,100)}$ \\
& Soluble oat fibre & AFSSA $(2007)^{(101)}$ \\
& Polydextrose & AFSSA (2002, 2003) $)^{(102,103)}$, ANSES $(2011)^{(104)}$ \\
EFSA (Europe) & Hydrocolloids (i.e. gums, mucilages, $\beta$-glucans) & \\
& Fructo-oligosaccharides, oligofructose and inulin & \\
& Galacto-oligosaccharides & \\
& Other resistant oligosaccharides & \\
& Resistant starch (RS1, 2, 3 and 4) & \\
& Arabinoxylan produced from wheat endosperm & EFSA (2011) \\
\end{tabular}

ANSES, Agence Nationale Française de Sécurité Sanitaire de l'Alimentation, de l'Environnement et du Travail; AFSSA, Agence Française de Sécurité Sanitaire des Aliments (French Agency for Food Safety).

chemical means must demonstrate a beneficial physiological effect. Tables 3-6 include information on non-digestible carbohydrates such as xanthan gum, even if no beneficial effect has so far been demonstrated. Science is evolving and evidence of health benefits may appear in the future to allow classification of such compounds as 'dietary fibre'.

Table 6 lists the main extracted and synthetic fibre materials or high-fibre fractions which are available for the enrichment of foods. It shows that fibre has been incorporated into a wide variety of foods, including dairy, meat or bakery products. The amount of fibre in the food as eaten can vary from less than $0 \cdot 2 \mathrm{~g}$ to $20 \mathrm{~g} /$ serving. These quantities are of interest as they determine whether or not a health claim can be made for the food in terms of its dietary fibre content. The EU Regulation (EC) No $1924 / 2006^{(20)}$ on nutrition and health claims for foods (slightly modified by a corrigendum in $2007^{(20)}$ ) specifies the requirement for the use of the terms 'source of fibre' or 'high in fibre':

(1) 'Source of fibre': a claim that a food is a source of fibre, and any claim likely to have the same meaning for the consumer, may only be made where the product contains at least $3 \mathrm{~g}$ of fibre per $100 \mathrm{~g}$ or at least $1.5 \mathrm{~g}$ of fibre per $100 \mathrm{kcal}(418 \mathrm{~kJ})$

(2) 'High fibre': a claim that a food is high in fibre, and any claim likely to have the same meaning for the consumer, may only be made where the product contains at least $6 \mathrm{~g}$ of fibre per $100 \mathrm{~g}$ or at least $3 \mathrm{~g}$ of fibre per $100 \mathrm{kcal}$ $(418 \mathrm{~kJ})$.

\section{Analytical methods}

Since dietary fibre can be declared on labels, it must be appropriately quantified. Analytical methods for dietary fibre used in Europe and elsewhere for the purpose of food labelling have changed over the years as the definition has evolved.

The TDF method of Prosky was developed and around the year 2000, the Association of Official Analytical Chemists International (AOAC) method 985.29 became the official method for dietary fibre in numerous countries ${ }^{(21)}$. This method requires enzymic digestion of protein and non-resistant starch, followed by precipitation of soluble fibre with $95 \%$ alcohol, followed by weighing. The method has been improved over time and now provides quasi-exhaustive quantification of all dietary fibre, even if further modifications are still ongoing. Moreover, specific methods have been developed to quantify specific fibre types, for example oligosaccharides, RS or $\beta$-glucans (Table 7 and Fig. 2). The most commonly used methods are AOAC 985.29, 991.43, 2001.03 and 2009.01(10).

Before 1995, the UK used the Southgate ${ }^{(22)}$ and Englyst ${ }^{(23-25)}$ methods and Sweden the Uppsala method ${ }^{(26,27)}$ to quantify dietary fibre in plant materials. NSP analysis proposed by Englyst et $a l^{(25)}$ was accepted by the Ministry of Agriculture, Fisheries and Food (the forerunner of the present Food Standards Agency) at the time and was used for nutrition and labelling purposes in the UK until 1999. This method is also still used in McCance and Widdowson's Table of Food Composition and hence is used in all food intake assessments in the UK. For the first time, the new version of McCance and Widdowson's The Composition of Foods, released in August 2014, has values for both NSP and dietary fibre using the method of the AOAC, and in future intakes may be described for both methods. Recently the UK Scientific Advisory Committee on Nutrition (SACN) has recommended the UK adopt the AOAC method 2009.01, which would bring it in line with most other nations $^{(28)}$.

\section{Dietary fibre recommendations and permitted health claims (Tables 8, 9 and 10)}

\section{Methods used to compile tables}

To collect information about recommendations for total fibre intake in Europe, and recommendations for specific fibre intakes throughout the world, a search was performed using Google and Google Scholar. Search terms were: fibre, fiber, carbohydrate, nutrient, nutrition, recommendation, and dietary reference value. Additional information was collected through personal contacts to various authorities.

An exhaustive list of health claims related to dietary fibre permitted in the EU, in the USA and in Australia/New Zealand was constructed based on data found on the EC website ${ }^{(29)}$ and on the Food and Drug Administration website ${ }^{(30)}$ and in Food Standards Australia New Zealand ${ }^{(31)}$. 
Table 6. Principal isolated and synthetic fibre sources or high-fibre fractions available for enrichment of foods

\begin{tabular}{|c|c|c|}
\hline Fibre type & Most common use & $\begin{array}{l}\text { Usual concentration in foods (g per } \\
\text { serving, or per } 100 \mathrm{~g} \text { food, or others) }\end{array}$ \\
\hline Acacia gum (gum arabic) E414 & $\begin{array}{l}\text { Fruit beverages } \\
\text { Confectionery }\end{array}$ & $5-20 \mathrm{~g} / \mathrm{d}$ \\
\hline \multirow{2}{*}{$\begin{array}{l}\text { Alginates (E401-E409) } \\
\text { Alqinic acid (E400) }\end{array}$} & Baked goods & \\
\hline & $\begin{array}{l}\text { Ice creams } \\
\text { lo }\end{array}$ & \\
\hline \multirow[t]{2}{*}{$\begin{array}{l}\text { Alginate of sodium, potassium, ammonium, calcium } \\
\text { propane-1,2-diol (E400, 401, 402, 403, } 404 \text { and 405) }\end{array}$} & $\begin{array}{l}\text { Dairy products } \\
\text { Spreads }\end{array}$ & \\
\hline & $\begin{array}{l}\text { Restructured products (meat, fruits, } \\
\text { legumes, fish) }\end{array}$ & \\
\hline Apple fibre & Beverages & $10 \mathrm{~g} /$ serving \\
\hline $\begin{array}{l}\text { Apple tibre } \\
\text { Arabinoxylans (from wheat, rye or rice) }\end{array}$ & Dietary supplements & $\begin{array}{l}1 \mathrm{~g} / \text { portion (rice arabinoxylans) } \\
8 \mathrm{~g} / 100 \mathrm{~g} \text { available carbohydrates } \\
\text { (wheat arabinoxylans from } \\
\text { endosperm) }\end{array}$ \\
\hline \multirow[t]{4}{*}{ Arabinoxylan-oligosaccharides } & Beverages & \\
\hline & Ready-to-eat cereals & \\
\hline & Biscuits & \\
\hline & $\begin{array}{l}\text { Bread } \\
\text { Dietary supplements }\end{array}$ & \\
\hline \multirow{4}{*}{ Bamboo fibre } & Minced meat & \\
\hline & Frozen food & \\
\hline & Ready-to-eat meals & \\
\hline & Bread and other baked products & \\
\hline \multirow[t]{4}{*}{$\beta$-Glucan (from barley, oats, yeast) } & Dairy products & $3-10 \mathrm{~g} / \mathrm{d}$ (from barley) \\
\hline & Beverages & $15 \mathrm{~g} / \mathrm{d}$ (from yeast) \\
\hline & Dietary supplements & $250 \mathrm{mg} / \mathrm{serving}$ \\
\hline & Bars for athletes & \\
\hline \multirow{2}{*}{ Carboxymethyl cellulose } & $\begin{array}{l}\text { Beverages } \\
\text { Dressings }\end{array}$ & \\
\hline & Soups and sauces & \\
\hline \multirow{4}{*}{ Carob fibre } & $\begin{array}{l}\text { lce cream } \\
\text { Baked goods }\end{array}$ & $1-5 g / 100 g$ \\
\hline & Bars & \\
\hline & Snacks & \\
\hline & $\begin{array}{l}\text { Dairy products } \\
\text { Cocoa-containing products }\end{array}$ & \\
\hline \multirow[t]{4}{*}{ Carrageenan (E407 and E407a) } & Desserts & \\
\hline & Ice cream & \\
\hline & Cream & \\
\hline & Pâtés and processed meats & \\
\hline \multirow{6}{*}{$\begin{array}{l}\text { Cellulose } \\
\text { (i) Microcystalline cellulose } \\
\text { (ii) Powdered cellulose (E460, 460(i) and 460(ii)) }\end{array}$} & Processed meat products & \\
\hline & Ready-made dishes & \\
\hline & Baked goods & \\
\hline & Instant products (i.e. soups and sauces) & \\
\hline & $\begin{array}{l}\text { Dairy products } \\
\text { Frozen dough, desserts }\end{array}$ & \\
\hline & Beverages & \\
\hline Chitosan & Dietary supplements & $300 \mathrm{mg} / \mathrm{dose}$ \\
\hline \multirow[t]{3}{*}{ Maize bran } & Breakfast cereals & $\begin{array}{l}1200 \mathrm{mg} / \mathrm{d} \\
5 \mathrm{~g} / \mathrm{serving}\end{array}$ \\
\hline & Chips & \\
\hline & $\begin{array}{l}\text { Breads } \\
\text { Muffins }\end{array}$ & \\
\hline \multirow{2}{*}{ Cyclodextrin (a, $\gamma$ and $\beta$ (E457, 458 and 459$)$ ) } & Baked goods & \\
\hline & Dairy products & \\
\hline \multirow[t]{4}{*}{ FOS and oligofructose } & Infant formula & $4 \mathrm{~g} / \mathrm{d}$ \\
\hline & Milk powders & $2-3 \mathrm{~g} / 250 \mathrm{ml}$ serving \\
\hline & Infant cereals & $4 \mathrm{~g} /$ serving \\
\hline & Dietary supplements & $5-20 \mathrm{~g} / \mathrm{d}$ \\
\hline GOS & Infant formulas & $8 \mathrm{~g} / \mathrm{l}$ of GOS:FOS (ratio $9: 1$ ) in infant \\
\hline & Milk beverages & formula \\
\hline & Baby foods & $1-7.5 \mathrm{~g}$ GOS/serving \\
\hline & Dairy products & \\
\hline & $\begin{array}{l}\text { Fruit drinks and water quenchers } \\
\text { Fruit preparations }\end{array}$ & \\
\hline Guar gum (galactomannan) (E412) & Ice cream & \\
\hline & Dairy desserts & \\
\hline & Bakery & \\
\hline & Beverages & \\
\hline Inulin & Growing-up milks & \\
\hline & Milk powders & $2-3 \mathrm{~g} / 250 \mathrm{ml}$ serving \\
\hline & Cereals and cereal bars & 5 \\
\hline & $\begin{array}{l}\text { Beverages (for example, instant milk + cereal } \\
\text { powders) }\end{array}$ & $3 \mathrm{~g} /$ serving \\
\hline Isomalto-oligosaccharides & Beverages & \\
\hline & Candy & \\
\hline & Chocolate and energy bars & \\
\hline & Confectionery products & \\
\hline Konjac & $\begin{array}{l}\text { MIllk products } \\
\text { Fruit ielly snacks }\end{array}$ & $1 \mathrm{~g} /$ serving \\
\hline (i) Konjac gum, (ii) Konjac glucomann (E425) & Vegan alternative seafood products & $3 \mathrm{~g} / \mathrm{d}$ \\
\hline & Noodles & \\
\hline
\end{tabular}


Table 6 Continued

\begin{tabular}{|c|c|c|}
\hline Fibre type & Most common use & $\begin{array}{l}\text { Usual concentration in foods ( } \mathrm{g} \text { per } \\
\text { serving, or per } 100 \mathrm{~g} \text { food, or others) }\end{array}$ \\
\hline $\begin{array}{l}\text { Lacto-sucrose } \\
\text { Locust bean gum ( = carob gum) (galactomannan) E410 }\end{array}$ & $\begin{array}{l}\text { Dietary supplements } \\
\text { Bakery } \\
\text { Canned products } \\
\text { Dairy products }\end{array}$ & \\
\hline $\begin{array}{l}\text { Modified celluloses } \\
\text { - Methyl, ethyl and hydroxypropyl cellulose (E461, } 462 \text { and } 463 \\
\text { - Hypromellose (hydroxypropyl methylcellulose) } \\
\text { Ethyl methyl, carboxymethylcellulose or sodium carboxy methyl } \\
\text { cellulose, ethyl hydroxyethyl cellulose (E464, } 465,466 \text { and } 46 \\
\text { - Enzymically hydrolysed carboxymethylcellulose (E469) }\end{array}$ & & \\
\hline $\begin{array}{l}\text { Oat bran } \\
\text { Oat fibre }\end{array}$ & $\begin{array}{l}\text { Breakfast cereals } \\
\text { Bakery (breads, etc.) } \\
\text { Breakfast cereals }\end{array}$ & $4-7 \mathrm{~g} /$ serving $(30-40 \mathrm{~g})$ \\
\hline Pea fibre & $\begin{array}{l}\text { Bakery (breads, cookies, etc.) } \\
\text { Snacks } \\
\text { Pasta }\end{array}$ & \\
\hline $\begin{array}{l}\text { Pea oligosaccharides } \\
\text { Pectins (E440) } \\
\text { (i) Pectin (E440(i)) } \\
\text { (ii) Amidated pectin) (E440(ii)) }\end{array}$ & $\begin{array}{l}\text { Candies } \\
\text { Jams } \\
\text { Dairy } \\
\text { Frozen desserts } \\
\text { Confectionery } \\
\text { Beverages } \\
\text { Fruits applications }\end{array}$ & \\
\hline Polydextrose (E1200) & $\begin{array}{l}\text { Dairy products } \\
\text { Baked goods } \\
\text { Beverages } \\
\text { Breakfast cereals and biscuits }\end{array}$ & $\begin{array}{l}2 \mathrm{~g} / 100 \mathrm{~g} \text { (drinks) } \\
4-12 \mathrm{~g} / \mathrm{d}\end{array}$ \\
\hline Potato fibre & $\begin{array}{l}\text { Meat and sausages } \\
\text { Bread and baked goods } \\
\text { Extrudants and doughs }\end{array}$ & \\
\hline Psyllium & $\begin{array}{l}\text { Dietary complements } \\
\text { Bakery products } \\
\text { Gluten free products } \\
\text { Pastas } \\
\text { Dairy and frozen desserts } \\
\text { Beverages }\end{array}$ & $2 \cdot 5-5 \mathrm{~g} /$ serving \\
\hline Resistant starch & $\begin{array}{l}\text { Bakery products } \\
\text { Pasta and noodles }\end{array}$ & \\
\hline Resistant dextrin & $\begin{array}{l}\text { Baked goods } \\
\text { Dairy and ice cream } \\
\text { Cereal and cereal bars } \\
\text { Bakery }\end{array}$ & 3-6 g/serving \\
\hline & $\begin{array}{l}\text { Milk powder } \\
\text { Beverages (for example, instant milk + cereal } \\
\text { powders) }\end{array}$ & $\begin{array}{l}2.5 \mathrm{~g} / 250 \mathrm{ml} \text { serving } \\
2.5 \mathrm{~g} / \mathrm{serving}\end{array}$ \\
\hline Rice bran & $\begin{array}{l}\text { Tortillas } \\
\text { Gluten-free pastas } \\
\text { Pizza }\end{array}$ & \\
\hline Rice fibre & $\begin{array}{l}\text { Baked goods } \\
\text { Cereals } \\
\text { Snacks } \\
\text { Nutrition bars } \\
\text { Bread }\end{array}$ & \\
\hline Soya fibre & $\begin{array}{l}\text { Bakery } \\
\text { Extruded snacks and cereals } \\
\text { Ground meats }\end{array}$ & \\
\hline \multicolumn{3}{|l|}{$\begin{array}{l}\text { Soybean hemicellulose (E426) } \\
\text { Soyabean oligosaccharides }\end{array}$} \\
\hline Sugarbeet fibre & $\begin{array}{l}\text { Bakery } \\
\text { Cereals and muesli } \\
\text { Meat products }\end{array}$ & $\begin{array}{l}1-5 \mathrm{~g} / 100 \mathrm{~g} \text { bread products } \\
1-10 \mathrm{~g} / 100 \mathrm{~g} \text { cereals and muesli } \\
1-5 \mathrm{~g} / 100 \mathrm{~g} \text { meat products }\end{array}$ \\
\hline Tara gum (E417) & $\begin{array}{l}\text { Sauces, dressings } \\
\text { Ice cream, dairy products } \\
\text { Jam, etc. }\end{array}$ & \\
\hline Tragacanth (E413) & $\begin{array}{l}\text { Ice cream, sherbet } \\
\text { Dairy products } \\
\text { Pudding }\end{array}$ & \\
\hline Xanthan gum (415) & $\begin{array}{l}\text { Savory (mayonnaise, dressings, etc.) } \\
\text { Beverages } \\
\text { Bakery } \\
\text { Dairy products }\end{array}$ & $9 \mathrm{~g} /$ serving $(36 \mathrm{~g})$ (cereal bar) \\
\hline Xylo-oligosaccharides (XOS) & $\begin{array}{l}\text { Milk and dairy } \\
\text { Puddings, custards } \\
\text { Ready-to-eat cereals }\end{array}$ & $0.2-2.4 \mathrm{~g} /$ serving \\
\hline Wheat bran & $\begin{array}{l}\text { Breakfast cereals } \\
\text { Bread } \\
\text { Bakery }\end{array}$ & Serving size: $15-30 \mathrm{~g}$ \\
\hline Wheat fibre & $\begin{array}{l}\text { Meat products } \\
\text { Frozen foods }\end{array}$ & \\
\hline
\end{tabular}

FOS, fructo-oligosaccharides; GOS, galacto-oligosaccharides. 
Table 7. Principal Association of Official Analytical Chemists International (AOAC) methods for total dietary fibre (TDF) and specific dietary fibre analysis

\begin{tabular}{|c|c|c|}
\hline Method & Fraction which is quantified & Comment \\
\hline AOAC $985.29^{*}$ & TDF & Quantifies most of the resistant starch \\
\hline AOAC $991.42^{*}$ & Insoluble dietary fibre & Quantifies most of the resistant starch \\
\hline AOAC $993.19^{*}$ & Soluble dietary fibre & \\
\hline AOAC $991.43^{*}$ & Total, insoluble, and soluble dietary fibre & $\begin{array}{l}\approx 985.29 \text { or } 991.42+993.19 \\
\text { Quantifies most of the resistant starch }\end{array}$ \\
\hline AOAC 995.16 & $\beta$-Glucans & \\
\hline AOAC 997.08 & Fructans (inulin, FOS) & \\
\hline AOAC 2001.03 & TDF including resistant maltodextrins & \\
\hline AOAC 2001.02 & Galacto-oligosaccharides & \\
\hline AOAC 2000.11 & Polydextrose & \\
\hline AOAC 2006.08 & Modified celluloses & \\
\hline AOAC 2002.02* & Resistant starch & \\
\hline AOAC 2009.01* & TDF (Codex definition) & $=991 \cdot 43+2001 \cdot 03+997 \cdot 08+200 \cdot 11+2001 \cdot 02$ \\
\hline
\end{tabular}

FOS, fructo-oligosaccharides.

* Cited by McCleary et al. ${ }^{(10)}$.

\begin{tabular}{|c|c|c|}
\hline AOAC 985.29 & AOAC 2001.03 & AOAC 2009.01 \\
\hline \multicolumn{3}{|c|}{ Enzymic digestion of starch } \\
\hline \multicolumn{2}{|l|}{$\alpha$-Amylase $95^{\circ} \mathrm{C}, 15 \mathrm{~min}$} & $\alpha$-Amylase $37^{\circ} \mathrm{C}, 16 \mathrm{~h}$ \\
\hline \multicolumn{3}{|c|}{ Recovery and assay of DF } \\
\hline \multicolumn{3}{|c|}{$\begin{array}{l}\text { Insoluble and soluble DF of high molecular weight (HMwDF) } \\
\text { (1) }\end{array}$} \\
\hline \multirow[t]{2}{*}{$\begin{array}{l}\text { Resistant starch* } \\
\text { (2) }\end{array}$} & $\begin{array}{l}\text { Resistant starch } \\
\text { (2) }\end{array}$ & $\begin{array}{l}\text { Resistant starch } \dagger \\
\text { (2) }\end{array}$ \\
\hline & \multicolumn{2}{|c|}{$\begin{array}{l}\text { Low-molecular-weight soluble DF } \\
\text { (3) }\end{array}$} \\
\hline $\mathrm{TDF}=(1)+(2)$ & $\mathrm{TDF}=(1)+(2)+(3)$ & $\mathrm{TDF}=(1)+(2)+(3)$ \\
\hline
\end{tabular}

Fig. 2. Main Association of Official Analytical Chemists International (AOAC) methods for total dietary fibre (TDF) analysis (adapted from Bar-L'Helgouac'h et al. ${ }^{(197)}$ ). ${ }^{*}$ Method quantifies part of resistant starch (RS). † Method quantifies all RS. DF, dietary fibre.

\section{Results}

Those countries that have recommendations for fibre intake all refer to total fibre. However, some countries specify that the fibre recommendations refer to natural occurring fibre in the diet from foods such as fruit, vegetables, pulses and cereal grains. None of the countries gives recommendations for specific types of fibre.

There remains insufficient information to be able to determine an Estimated Average Requirement (EAR) and thus calculate an RDA for dietary fibre. (EAR is a nutrient intake value that is estimated to meet the requirement of half the healthy individuals in a group; RDA is the average daily dietary intake level that is sufficient to meet the nutrient requirement of nearly all (97 to 98\%) healthy individuals in a group; Adequate Intake (AI) is a value based on observed or experimentally determined approximations of nutrient intake by a group (or groups) of healthy people - used when an RDA cannot be determined.) An AI has been developed instead, based on intakes that have been observed to provide health benefits related to bowel function, maintaining or reducing blood cholesterol or modulating postprandial blood glucose response or protecting against certain diseases. Table 8 provides the recommendations (AI) for total fibre intake in different countries for different age groups. Most countries recommend a daily intake of dietary fibre of 25-35 g for adults (25-32 g/d for adult women and $30-35 \mathrm{~g} / \mathrm{d}$ for adult men) and less for children and older adults depending on age, corresponding to approximately 3-4 g/MJ.

A list of health claims related to dietary fibre permitted in the EU, in the USA and in Australia and New Zealand is presented in Table 9. For the European health claims related to bowel function, the foods must be 'high in' the particular fibre mentioned in the claim, which means the food should provide at least $6 \mathrm{~g} / 100 \mathrm{~g}$ or $3 \mathrm{~g} / 100 \mathrm{kcal}(418 \mathrm{~kJ}$ ) (corresponding to at least $7 \mathrm{~g} / \mathrm{MJ}$ ). For claims related to postprandial glycaemia, the necessary amount of the specific fibre is generally related to the available carbohydrate in the product. For claims related to cardiovascular health, the amount varies between 3 and $10 \mathrm{~g}$ of the specific fibre per $d$. Claims for which a specific fibre intake for beneficial effect is stated could possibly be seen as a recommendation for intake of that fibre. The US health claims do not specify the types of dietary fibre, just the foods that provide the fibre.

If the substances that are the subject of health claims are considered as recommended for intake, this would suggest that 


\section{NS Nutrition Research Reviews}

Table 8. Recommendations (Adequate Intake) for average population total fibre intake in different age groups

\begin{tabular}{|c|c|c|c|c|c|}
\hline \multirow[b]{2}{*}{ Country } & \multicolumn{2}{|c|}{ Recommended intake (g/MJ) } & \multicolumn{2}{|c|}{ Recommended intake (g/d) } & \multirow[b]{2}{*}{ Reference } \\
\hline & Children & Adults & Children & Adults & \\
\hline Belgium & & & & $\begin{array}{l}\text { F: } 30 \\
\text { M } 15-18 \text { years: } 40 \\
\text { M } 19->75 \text { years: } 30\end{array}$ & Lin et al. $2011^{(107)}$ \\
\hline Estonia & & & $5+$ age & $25-35$ & Vaask et al. $2006^{(108)}$ \\
\hline $\begin{array}{l}\text { Europe } \\
\text { France }\end{array}$ & & 3 & $5+\mathrm{age}$ & $\begin{array}{l}>25 \\
30\end{array}$ & $\begin{array}{l}\text { ESFA } 2010^{(109)} \\
\text { Martin 2001 }\end{array}$ \\
\hline $\begin{array}{l}\text { Germany, Austria, } \\
\text { Switzerland }\end{array}$ & & $\begin{array}{l}\text { F: } 3 \\
\text { M: } 2 \cdot 4\end{array}$ & & $\geq 30$ & Deutsche Gesellschaft für Ernährung et al. 2008 ${ }^{(110)}$ \\
\hline $\begin{array}{l}\text { Greece } \\
\text { Hungary }\end{array}$ & & & & EC 1993 recommendations & Rodler $2005^{(111)}$ \\
\hline $\begin{array}{l}\text { Ireland } \\
\text { Italy }\end{array}$ & Developmental age ( $\geq 1$ years): 2 & 3-4 (RI) & & $25-35$ & $\begin{array}{l}\text { Cho et al. } 1987^{(112)} \\
\text { Società Italiana di Comunicazione Scientifica e } \\
\text { Sanitaria } 2012^{(113)}\end{array}$ \\
\hline $\begin{array}{l}\text { Latvia } \\
\text { Lithuania } \\
\text { Luxembourg }\end{array}$ & & & & $\begin{array}{l}\text { No recommendations } \\
\text { No recommendations } \\
\text { No recommendations }\end{array}$ & \\
\hline The Netherlands & $\begin{array}{l}1-3 \text { years: } 2 \cdot 8 \\
4-8 \text { years: } 3 \cdot 0 \\
9-13 \text { years: } 3 \cdot 2 \\
14-18 \text { years: } 3 \cdot 4\end{array}$ & $3 \cdot 4$ & & $32-45 \mathrm{~g} / \mathrm{d}$ & $\begin{array}{l}\text { Health Council of the Netherlands } 2001 \text { and } \\
2006^{(114,115)}\end{array}$ \\
\hline Nordic countries & $\begin{array}{l}1-17 \text { years: } 2-3 \text {, from school age } \\
(6 \text { years) increasing to level } \\
\text { recommended for adults }\end{array}$ & 3 & $\begin{array}{l}\geq 6 \text { years (school age): } 10, \\
\text { increasing gradually to } \\
\text { adult recommended level }\end{array}$ & $\begin{array}{l}\text { F: } 25 \\
\text { M: } 35\end{array}$ & Nordic Nutrition Recommendations $2012^{(116)}$ \\
\hline Poland & & & $\begin{array}{l}1-3 \text { years: } 10 \\
4-6 \text { years: } 14 \\
7-9 \text { years: } 16 \\
10-12 \text { years: } 19 \\
13-15 \text { years: } 19 \\
16-18 \text { years: } 21\end{array}$ & $\begin{array}{l}19-30 \text { years: } 25 \\
31-50 \text { years: } 25 \\
51-65 \text { years: } 25 \\
66-75 \text { years: } 20 \\
>75 \text { years: } 20\end{array}$ & National Food and Nutrition Institute $2012^{(117)}$ \\
\hline $\begin{array}{l}\text { Portugal } \\
\text { Romania }\end{array}$ & & & & $\begin{array}{l}27-40 \\
25-35^{2}\end{array}$ & $\begin{array}{l}\text { Graça } 1999^{(118)} \\
\text { Romanian Society of Diabetes, Nutrition and Metabolic } \\
\text { Diseases } 2015^{(119)}\end{array}$ \\
\hline Slovakia & & & $\begin{array}{l}0-6 \text { months: } 1 \\
7-12 \text { months: } 3 \\
1-3 \text { years: } 10 \\
\text { 4-6 years: } 14 \\
7-10 \text { years: } 17 \\
\text { F } 11-14 \text { years: } 18 \\
\text { M } 11-14 \text { years: } 20 \\
\text { F } 15-18 \text { years: } 18-22 \\
\text { M } 15-18 \text { years: } 22-25\end{array}$ & $\begin{array}{l}\text { F } 19-54 \text { years: } 22-26^{3} \\
\text { M 19-34 years: } 26-32^{3} \\
\text { M 35-59 years: } 24-30^{3} \\
\text { F } 55-74 \text { years: } 20 \\
\text { M 60-74 years: } 22 \\
\text { F >75 years: } 18 \\
\text { M > }>75 \text { years: } 20 \\
\text { Pregnant F: } 26 \\
\text { Lactating F: } 28\end{array}$ & Slovakian Public Health Authority $2015^{(120)}$ \\
\hline Slovenia & $2 \cdot 4$ & $\begin{array}{l}F: 3 \\
M: 2 \cdot 4\end{array}$ & & 30 & German Nutrition Society et al. 2004 $4^{(121)}$ \\
\hline $\begin{array}{l}\text { UK } \\
\text { USA }\end{array}$ & All ages $\geq 1$ years: 3.4 & $\begin{array}{r}\text { All ages } \geq 1 \\
\quad \text { years: } 3 \cdot 4\end{array}$ & $\begin{array}{l}1-3 \text { years: } 19 \\
\text { 4-8 years: } 25 \\
\text { F 9-13 years: } 26 \\
\text { M 9-13 years: } 31 \\
\text { F } 14-18 \text { years: } 26 \\
\text { M } 14-18 \text { years: } 38\end{array}$ & $\begin{array}{l}18 \text { (range } 12-24)^{4} \\
\text { F 19-50 years: } 25 \\
\text { M 19-50 years: } 38 \\
\text { F > 51 years: } 21 \\
M>51 \text { years: } 30\end{array}$ & $\begin{array}{l}\text { Department of Health } 1991^{(122)} \\
\text { Institute of Medicine } 2005^{(7)}\end{array}$ \\
\hline $\begin{array}{l}\text { Australia/New } \\
\text { Zealand }\end{array}$ & & & $\begin{array}{l}\text { 1-3 years: } 14 \\
4-8 \text { years: } 18 \\
\text { F 9-13 years: } 20 \\
\text { M 9-13 years: } 24 \\
\text { F } 14-18 \text { years: } 22 \\
\text { M } 14-18 \text { years: } 28\end{array}$ & $\begin{array}{l}\text { F: } 25 \\
\text { M: } 30\end{array}$ & $\begin{array}{l}\text { Australian National Health and Medical Research } \\
\text { Council } 2006^{(31)}\end{array}$ \\
\hline WHO & & & & $>25$ & World Health Organization $2003^{(123)}$ \\
\hline
\end{tabular}

$\mathrm{F}$, female; $\mathrm{M}$, male; $\mathrm{RI}$, recommended intake.

1 Insoluble fibre:soluble fibre ratio $3: 1$.

$75 \%$ insoluble, $25 \%$ soluble.

${ }^{4}$ NSP. 
Table 9. Authorised health claims related to dietary fibre in the European Union (EU) (European Commission 2014), in the USA (Food and Drug Administration 2013) and in Australia/New Zealand (Food Standards Australia New Zealand 2013)

\begin{tabular}{|c|c|c|c|c|c|}
\hline Country & Subject of the claim & Claim & Conditions of use & Remarks & Reference \\
\hline $\begin{array}{l}\text { Article 13(1) } \\
\text { EU }\end{array}$ & $\begin{array}{l}\text { a-Cyclodextrin and reduction of } \\
\text { postprandial glycaemic } \\
\text { responses }\end{array}$ & $\begin{array}{l}\text { Consumption of a-cyclodextrin as part of a } \\
\text { starch-containing meal contributes to the } \\
\text { reduction of the blood glucose rise after } \\
\text { that meal }\end{array}$ & $\begin{array}{l}\text { The claim may be used for food which } \\
\text { contains at least } 5 \mathrm{~g} \text { of a-cyclodextrin per } \\
50 \mathrm{~g} \text { of starch in a quantified portion as } \\
\text { part of the meal }\end{array}$ & $\begin{array}{l}\text { Information shall be given to the consumer } \\
\text { that the beneficial effect is obtained by } \\
\text { consuming the a-cyclodextrin as part of } \\
\text { the meal }\end{array}$ & $\begin{array}{l}\text { EU Commission }^{(124)} \\
\text { EFSA }^{(125,126)}\end{array}$ \\
\hline EU & $\begin{array}{l}\text { Arabinoxylan produced from } \\
\text { wheat endosperm and } \\
\text { reduction of postprandial } \\
\text { glycaemic responses }\end{array}$ & $\begin{array}{l}\text { Consumption of arabinoxylan as part of a } \\
\text { meal contributes to a reduction of the } \\
\text { blood glucose rise after that meal }\end{array}$ & $\begin{array}{l}\text { The claim may be used only for food which } \\
\text { contains at least } 8 \mathrm{~g} \text { of arabinoxylan-rich } \\
\text { fibre produced from wheat endosperm } \\
\text { (at least } 60 \% \text { arabinoxylan by weight) } \\
\text { per } 100 \mathrm{~g} \text { of available carbohydrates in a } \\
\text { quantified portion as part of the meal }\end{array}$ & $\begin{array}{l}\text { Information shall be given to the consumer } \\
\text { that the beneficial effect is obtained by } \\
\text { consuming the arabinoxylan-rich fibre } \\
\text { produced from wheat endosperm as part } \\
\text { of the meal }\end{array}$ & $\begin{array}{l}\text { EU Commission }^{(127)} \\
\text { EFSA }^{(128)}\end{array}$ \\
\hline EU & $\begin{array}{l}\text { Barley grain fibre and increase in } \\
\text { faecal bulk }\end{array}$ & $\begin{array}{l}\text { Barley grain fibre contributes to an increase } \\
\text { in faecal bulk }\end{array}$ & $\begin{array}{l}\text { The claim may be used only for food which } \\
\text { is high in that fibre } \text { as referred to in the } \\
\text { claim HIGH FIBRE as listed in the Annex } \\
\text { to Regulation (EC) No 1924/2006 }\end{array}$ & & $\begin{array}{l}\text { EU Commission }^{(127)} \\
\text { EFSA }^{(129)}\end{array}$ \\
\hline EU & $\begin{array}{l}\beta \text {-Glucans and maintenance of } \\
\text { normal blood cholesterol } \\
\text { concentrations }\end{array}$ & $\begin{array}{l}\beta \text {-Glucans contribute to the maintenance of } \\
\text { normal blood cholesterol levels }\end{array}$ & $\begin{array}{l}\text { The claim may be used only for food which } \\
\text { contains at least } 1 \mathrm{~g} \text { of } \beta \text {-glucans from } \\
\text { oats, oat bran, barley, barley bran, or } \\
\text { from mixtures of these sources per } \\
\text { quantified portion }\end{array}$ & $\begin{array}{l}\text { Information shall be given to the consumer } \\
\text { that the beneficial effect is obtained with } \\
\text { a daily intake of } 3 \mathrm{~g} \text { of } \beta \text {-glucans from } \\
\text { oats, oat bran, barley, barley bran, or } \\
\text { from mixtures of these } \beta \text {-glucans }\end{array}$ & $\begin{array}{l}\text { EU Commission }{ }^{(127)} \\
\text { EFSA }^{(129,130)}\end{array}$ \\
\hline EU & $\begin{array}{l}\beta \text {-Glucans from oats and barley } \\
\text { and reduction of postprandial } \\
\text { glycaemic responses }\end{array}$ & $\begin{array}{l}\text { Consumption of } \beta \text {-glucans from oats or } \\
\text { barley as part of a meal contributes to the } \\
\text { reduction of the blood glucose rise after } \\
\text { that meal }\end{array}$ & $\begin{array}{l}\text { The claim may be used only for food which } \\
\text { contains at least } 4 \mathrm{~g} \text { of } \beta \text {-glucans from } \\
\text { oats or barley for each } 30 \mathrm{~g} \text { of available } \\
\text { carbohydrates in a quantified portion as } \\
\text { part of the meal }\end{array}$ & $\begin{array}{l}\text { Information shall be given to the consumer } \\
\text { that the beneficial effect is obtained by } \\
\text { consuming the } \beta \text {-glucans from oats or } \\
\text { barley as part of the meal }\end{array}$ & $\begin{array}{l}\text { EU Commission } \\
\text { EFSA }^{(127)}\end{array}$ \\
\hline EU & $\begin{array}{l}\text { Chitosan and maintenance of } \\
\text { normal blood LDL-cholesterol } \\
\text { concentrations }\end{array}$ & $\begin{array}{l}\text { Chitosan contributes to the maintenance of } \\
\text { normal blood cholesterol levels }\end{array}$ & $\begin{array}{l}\text { The claim may be used only for food which } \\
\text { provides a daily intake of } 3 \mathrm{~g} \text { of chitosan }\end{array}$ & $\begin{array}{l}\text { Information shall be given to the consumer } \\
\text { that the beneficial effect is obtained with } \\
\text { a daily intake of } 3 \mathrm{~g} \text { of chitosan }\end{array}$ & $\begin{array}{l}\text { EU Commission }^{(127)} \\
\text { EFSA }^{(131)}\end{array}$ \\
\hline EU & $\begin{array}{l}\text { Glucomannan (konjac mannan) } \\
\text { and maintenance of normal } \\
\text { blood cholesterol } \\
\text { concentrations }\end{array}$ & $\begin{array}{l}\text { Glucomannan contributes to the } \\
\text { maintenance of normal blood cholesterol } \\
\text { levels }\end{array}$ & $\begin{array}{l}\text { The claim may be used only for food which } \\
\text { provides a daily intake of } 4 \mathrm{~g} \text { of } \\
\text { glucomannan }\end{array}$ & $\begin{array}{l}\text { Information shall be given to the consumer } \\
\text { that the beneficial effect is obtained with } \\
\text { a daily intake of } 4 \mathrm{~g} \text { of glucomannan. } \\
\text { Warning of choking to be given for } \\
\text { individuals with swallowing difficulties or } \\
\text { when ingesting with inadequate fluid } \\
\text { intake - advice on taking with plenty of } \\
\text { water to ensure substance reaches } \\
\text { stomach }\end{array}$ & $\begin{array}{l}\text { EU Commission } \\
\text { EFSA }^{(126,127)}\end{array}$ \\
\hline EU & $\begin{array}{l}\text { Glucomannan (konjac mannan) } \\
\text { and reduction of body weight }\end{array}$ & $\begin{array}{l}\text { Glucomannan in the context of an energy- } \\
\text { restricted diet contributes to weight loss }\end{array}$ & $\begin{array}{l}\text { The claim may be used only for food which } \\
\text { contains } 1 \mathrm{~g} \text { of glucomannan per } \\
\text { quantified portion }\end{array}$ & $\begin{array}{l}\text { Information shall be given to the consumer } \\
\text { that the beneficial effect is obtained with } \\
\text { a daily intake of } 3 \mathrm{~g} \text { of glucomannan in } \\
\text { three doses of } 1 \mathrm{~g} \text { each, together with } \\
1-2 \text { glasses of water, before meals and } \\
\text { in the context of an energy-restricted diet }\end{array}$ & $\begin{array}{l}\text { EU Commission } \\
\text { EFSA }^{(127)}\end{array}$ \\
\hline EU & $\begin{array}{l}\text { Guar gum and maintenance of } \\
\text { normal blood cholesterol } \\
\text { concentrations }\end{array}$ & $\begin{array}{l}\text { Guar gum contributes to the maintenance of } \\
\text { normal blood cholesterol levels }\end{array}$ & $\begin{array}{l}\text { The claim may be used only for food which } \\
\text { provides a daily intake of } 10 \mathrm{~g} \text { of guar } \\
\text { gum }\end{array}$ & $\begin{array}{l}\text { Information shall be given to the consumer } \\
\text { that the beneficial effect is obtained with a } \\
\text { daily intake of } 10 \mathrm{~g} \text { of guar gum. Warning } \\
\text { of choking to be given for individuals with } \\
\text { swallowing difficulties or when ingesting } \\
\text { with inadequate fluid intake - advice on } \\
\text { taking with plenty of water to ensure } \\
\text { substance reaches stomach }\end{array}$ & $\begin{array}{l}\text { EU Commission } \\
\text { EFSA }^{(127)}\end{array}$ \\
\hline EU & $\begin{array}{l}\text { Oat grain fibre and increase in } \\
\text { faecal bulk }\end{array}$ & $\begin{array}{l}\text { Oat grain fibre contributes to an increase in } \\
\text { faecal bulk }\end{array}$ & $\begin{array}{l}\text { The claim may be used only for food which } \\
\text { is high in that fibre } \text { as referred to in the } \text { claim HIGH FIBRE as listed in the Annex } \\
\text { to Regulation (EC) No 1924/2006 }\end{array}$ & & $\begin{array}{l}\text { EU Commission } \\
\text { EFSA }^{(127)}\end{array}$ \\
\hline
\end{tabular}


Table 9 Continued

\begin{tabular}{|c|c|c|c|c|c|}
\hline Country & Subject of the claim & Claim & Conditions of use & Remarks & Reference \\
\hline EU & $\begin{array}{l}\text { Pectins and reduction of } \\
\text { postprandial glycaemic } \\
\text { responses }\end{array}$ & $\begin{array}{l}\text { Consumption of pectins with a meal } \\
\text { contributes to the reduction of the blood } \\
\text { glucose rise after that meal }\end{array}$ & $\begin{array}{l}\text { The claim may be used only for food which } \\
\text { contains } 10 \mathrm{~g} \text { of pectins per quantified } \\
\text { portion }\end{array}$ & $\begin{array}{l}\text { Information shall be given to the consumer } \\
\text { that the beneficial effect is obtained by } \\
\text { consuming } 10 \mathrm{~g} \text { of pectins as part of the } \\
\text { meal. Warning of choking to be given for } \\
\text { individuals with swallowing difficulties or } \\
\text { when ingesting with inadequate fluid intake } \\
\text { - advice on taking with plenty of water to } \\
\text { ensure substance reaches stomach }\end{array}$ & $\begin{array}{l}\text { EU Commission }{ }^{(127)} \\
\text { EFSA }^{(86)}\end{array}$ \\
\hline EU & $\begin{array}{l}\text { Pectins and maintenance of } \\
\text { normal blood cholesterol } \\
\text { concentrations }\end{array}$ & $\begin{array}{l}\text { Pectins contribute to the maintenance of } \\
\text { normal blood cholesterol levels }\end{array}$ & $\begin{array}{l}\text { The claim may be used only for food which } \\
\text { provides a daily intake of } 6 \mathrm{~g} \text { of pectins }\end{array}$ & $\begin{array}{l}\text { Information shall be given to the consumer } \\
\text { that the beneficial effect is obtained with } \\
\text { a daily intake of } 6 \mathrm{~g} \text { of pectins. Warning } \\
\text { of choking to be given for individuals with } \\
\text { swallowing difficulties or when ingesting } \\
\text { with inadequate fluid intake - advice on } \\
\text { taking with plenty of water to ensure } \\
\text { substance reaches stomach }\end{array}$ & $\begin{array}{l}\text { EU Commission } \\
\text { EFSA }^{(127), 129)}\end{array}$ \\
\hline EU & $\begin{array}{l}\text { Resistant starch and reduction of } \\
\text { postprandial glycaemic } \\
\text { responses }\end{array}$ & $\begin{array}{l}\text { Replacing digestible starches with resistant } \\
\text { starch in a meal contributes to a reduction } \\
\text { in the blood glucose rise after that meal }\end{array}$ & $\begin{array}{l}\text { The claim may be used only for food in } \\
\text { which digestible starch has been } \\
\text { replaced by resistant starch so that the } \\
\text { final content of resistant starch is at least } \\
14 \% \text { of total starch }\end{array}$ & & $\begin{array}{l}\text { EU Commission }^{(127)} \\
\text { EFSA }^{(133)}\end{array}$ \\
\hline EU & $\begin{array}{l}\text { Rye fibre and changes in bowel } \\
\text { function }\end{array}$ & $\begin{array}{l}\text { Rye fibre contributes to normal bowel } \\
\text { function }\end{array}$ & $\begin{array}{l}\text { The claim may be used only for food which } \\
\text { is high in that fibre }{ }^{6} \text { as referred to in the } \\
\text { claim HIGH FIBRE as listed in the Annex } \\
\text { to Regulation (EC) No 1924/2006 }\end{array}$ & & $\begin{array}{l}\text { EU Commission }^{(127)} \\
\text { EFSA }^{(134)}\end{array}$ \\
\hline EU & $\begin{array}{l}\text { Wheat bran fibre and reduction } \\
\text { in intestinal transit time }\end{array}$ & $\begin{array}{l}\text { Wheat bran fibre contributes to an } \\
\text { acceleration of intestinal transit }\end{array}$ & $\begin{array}{l}\text { The claim may be used only for food which } \\
\text { is high in that fibre }{ }^{6} \text { as referred to in the } \\
\text { claim HIGH FIBRE as listed in the Annex } \\
\text { to Regulation (EC) No 1924/2006 }\end{array}$ & $\begin{array}{l}\text { Information shall be given to the consumer } \\
\text { that the claimed effect is obtained with a } \\
\text { daily intake of at least } 10 \mathrm{~g} \text { of wheat bran } \\
\text { fibre }\end{array}$ & $\begin{array}{l}\text { EU Commission } \\
\text { EFSA }^{(127)}\end{array}$ \\
\hline EU & $\begin{array}{l}\text { Wheat bran fibre and increase in } \\
\text { faecal bulk }\end{array}$ & $\begin{array}{l}\text { Wheat bran fibre contributes to an increase } \\
\text { in faecal bulk }\end{array}$ & $\begin{array}{l}\text { The claim may be used only for food which } \\
\text { is high in that fibre }{ }^{6} \text { as referred to in the } \\
\text { claim HIGH FIBRE as listed in the Annex } \\
\text { to Regulation (EC) No 1924/2006 }\end{array}$ & & $\begin{array}{l}\text { EU Commission }^{(127)} \\
\text { EFSA }^{(136)}\end{array}$ \\
\hline $\begin{array}{l}\text { Article 13(5) } \\
\text { EU }\end{array}$ & Sugarbeet fibre & Sugarbeet fibre and increasing faecal bulk & $\begin{array}{l}\text { The claim may be used only for food which } \\
\text { is high in that fibre } \text { as referred to in the } \\
\text { claim HIGH FIBRE as listed in the Annex } \\
\text { to Regulation (EC) No 1924/2006 }\end{array}$ & & $\begin{array}{l}\text { EU Commission }^{(137)} \\
\text { EFSA }^{(138)}\end{array}$ \\
\hline $\begin{array}{l}\text { Article } 14(1)(a) \\
\text { EU }\end{array}$ & $\begin{array}{l}\text { Barley } \beta \text {-glucans and risk of } \\
\text { (coronary) heart disease }\end{array}$ & $\begin{array}{l}\text { Barley } \beta \text {-glucan has been shown to lower/ } \\
\text { reduce blood cholesterol. High cholesterol } \\
\text { is a risk factor in the development of CHD }\end{array}$ & $\begin{array}{l}\text { The claim can be used for foods which } \\
\text { provide at least } 1 \mathrm{~g} \text { of barley } \beta \text {-glucan } \\
\text { per quantified portion }\end{array}$ & $\begin{array}{l}\text { Information shall be given to the consumer } \\
\text { that the beneficial effect is obtained with } \\
\text { a daily intake of } 3 \mathrm{~g} \text { of barley } \beta \text {-glucan }\end{array}$ & $\begin{array}{l}\text { EU Commission } \\
\text { EFSA }^{(140,1411)}\end{array}$ \\
\hline EU & $\begin{array}{l}\text { Oat } \beta \text {-glucan and risk of heart } \\
\text { disease }\end{array}$ & $\begin{array}{l}\text { Oat } \beta \text {-glucan has been shown to lower/ } \\
\text { reduce blood cholesterol. High cholesterol } \\
\text { is a risk factor in the development of CHD }\end{array}$ & $\begin{array}{l}\text { The claim can be used for foods which } \\
\text { provide at least } 1 \mathrm{~g} \text { of oat } \beta \text { glucan per } \\
\text { quantified portion }\end{array}$ & $\begin{array}{l}\text { Information shall be given to the consumer } \\
\text { that the beneficial effect is obtained with } \\
\text { a daily intake of } 3 \mathrm{~g} \text { of oat } \beta \text {-glucan }\end{array}$ & $\begin{array}{l}\text { EU Commission }{ }^{(142)} \\
\text { EFSA }^{(143)}\end{array}$ \\
\hline USA & $\begin{array}{l}\text { Fibre-containing grain products, } \\
\text { fruits and vegetables and risk } \\
\text { of cancer }\end{array}$ & $\begin{array}{l}\text { Model claim: low-fat diets rich in fibre- } \\
\text { containing grain products, fruits, and } \\
\text { vegetables may reduce the risk of some } \\
\text { types of cancer, a disease associated with } \\
\text { many factors }\end{array}$ & $\begin{array}{l}\text { The food shall meet, without fortification, } \\
\text { the nutrient content requirements for a } \\
\text { 'good source'1 of dietary fibre, and shall } \\
\text { be a 'low-fat'" food }\end{array}$ & $\begin{array}{l}\text { The claim is limited to foods that are or } \\
\text { contain grain product, fruit, and vegetable } \\
\text { that contain dietary fibre. } \\
\text { The claim does not specify types of dietary } \\
\text { fibre that may be related to risk of cancer }\end{array}$ & $\begin{array}{l}\text { Code of Federal } \\
\text { Regulations }\end{array}$ \\
\hline USA & $\begin{array}{l}\text { Fruits, vegetables and grain } \\
\text { products that contain fibre, } \\
\text { particularly soluble fibre, and } \\
\text { risk of } C H D^{5}\end{array}$ & $\begin{array}{l}\text { Model claim: diets low in saturated fat and } \\
\text { cholesterol and rich in fruits, vegetables, } \\
\text { and grain products that contain some types } \\
\text { of dietary fibre, particularly soluble fibre, } \\
\text { may reduce the risk of heart disease, a } \\
\text { disease associated with many factors }\end{array}$ & $\begin{array}{l}\text { The food shall meet the requirement for a } \\
\text { 'low saturated fat' }{ }^{3} \text {, 'low cholesterol' } \\
\text { and 'low-fat'" food. The food shall } \\
\text { contain, without fortification, at least } \\
0.6 \mathrm{~g} \text { of soluble fibre per RACC }\end{array}$ & $\begin{array}{l}\text { The claim is limited to those fruits, } \\
\text { vegetables, and grains that contain fibre. } \\
\text { The term 'fibre', 'dietary fibre', 'some (types } \\
\text { of) dietary fibre', 'some (dietary) fibres', } \\
\text { or 'soluble fibre' may be used }\end{array}$ & $\begin{array}{l}\text { Code of Federal } \\
\text { Regulations } \\
{ }^{(145)}\end{array}$ \\
\hline
\end{tabular}




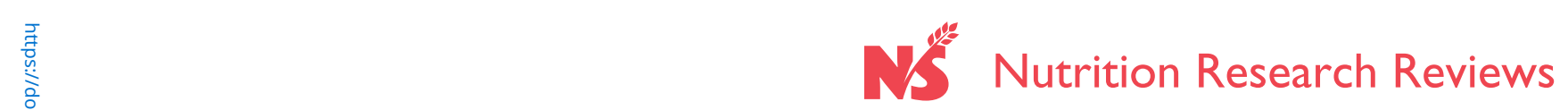

Table 9 Continued

\begin{tabular}{|c|c|c|c|c|c|}
\hline Country & Subject of the claim & Claim & Conditions of use & Remarks & Reference \\
\hline USA & $\begin{array}{l}\text { Soluble fibre from certain foods } \\
\text { and risk of } \mathrm{CHD}\end{array}$ & $\begin{array}{l}\text { Model claim: soluble fibre from foods such as } \\
\text { [name of soluble fibre source], as part of a } \\
\text { diet low in saturated fat and cholesterol, } \\
\text { may reduce the risk of heart disease. A } \\
\text { serving of [name of food] supplies } \\
\text { grams of [the soluble fibre] necessary } \\
\text { per day to have this effect }\end{array}$ & $\begin{array}{l}\text { The food shall be a 'low saturated fat }{ }^{3} \text { and } \\
\text { 'low cholesterol' } \text { food. The food shall } \\
\text { also be a 'low-fat' }{ }^{2} \text { food, unless the food } \\
\text { exceeds the fat content due to fat } \\
\text { derived from whole oats. Whole oats or } \\
\text { barley foods shall contain at least } 0.75 \mathrm{~g} \\
\text { of soluble fibre per RACC. Oatrim or } \\
\text { barley } \beta \text { fibre shall contain at least } 0.75 \mathrm{~g} \\
\text { of } \beta \text {-glucan fibre per RACC. Psyllium } \\
\text { husk and psyllium food shall contain at } \\
\text { least } 1.7 \mathrm{~g} \text { of soluble fibre per RACC }\end{array}$ & $\begin{array}{l}\text { The claim can be used on foods containing } \\
\text { oat bran, rolled oats, whole oat flour, } \\
\text { Oatrim, whole grain barley and dry } \\
\text { milled barley, Barley } \beta \text { fibre, or psyllium } \\
\text { husk. } \\
\text { The claim may specify the name of the } \\
\text { eligible soluble fibre }\end{array}$ & $\begin{array}{l}\text { Code of Federal } \\
\text { Regulations } \\
(145)\end{array}$ \\
\hline \multicolumn{6}{|c|}{ High-level health claims } \\
\hline $\begin{array}{l}\text { Australia/New } \\
\text { Zealand }\end{array}$ & $\beta$-Glucan & Reduces blood cholesterol & $\begin{array}{l}\text { The food must contain: } \\
\text { (a) one or more of the following oat or } \\
\text { barley foods: } \\
\text { (i) oat bran; } \\
\text { (ii) wholegrain oats; or } \\
\text { (iii) wholegrain barley; and } \\
\text { (b) at least } 1 \mathrm{~g} / \mathrm{serving} \text { of } \beta \text {-glucan from the } \\
\text { foods listed in (a) }\end{array}$ & $\begin{array}{l}\text { Diet low in SFA } \\
\text { Diet containing } 3 g \text { of } \beta \text {-glucan per } d\end{array}$ & $\begin{array}{l}\text { Standard } 1.2 .7 \\
\text { Nutrition, Health and } \\
\text { Related claims; } \\
\text { Food Standards } \\
\text { Australia New } \\
\text { Zealand } 2013^{(5)}\end{array}$ \\
\hline \multicolumn{6}{|c|}{ General-level health claims } \\
\hline $\begin{array}{l}\text { Australia/New } \\
\text { Zealand }\end{array}$ & $\beta$-Glucan & $\begin{array}{l}\text { Reduces dietary and biliary cholesterol } \\
\text { absorption }\end{array}$ & $\begin{array}{l}\text { The food must contain: } \\
\text { (a) one or more of the following oat or } \\
\text { barley foods: } \\
\text { (i) oat bran; } \\
\text { (ii) wholegrain oats; or } \\
\text { (iii) wholegrain barley; and } \\
\text { (b) at least } 1 \mathrm{~g} / \mathrm{serving} \text { of } \beta \text {-glucan from the } \\
\text { foods listed in (a) }\end{array}$ & $\begin{array}{l}\text { Diet low in SFA } \\
\text { Diet containing } 3 g \text { of } \beta \text {-glucan per } d\end{array}$ & $\begin{array}{l}\text { Standard } 1.2 .7 \\
\text { Nutrition, Health and } \\
\text { Related claims; } \\
\text { Food Standards } \\
\text { Australia New } \\
\text { Zealand } 2013^{(5)}\end{array}$ \\
\hline $\begin{array}{l}\text { Australia/New } \\
\text { Zealand }\end{array}$ & Dietary fibre & Contributes to regular laxation & $\begin{array}{l}\text { The food must meet the general conditions } \\
\text { for making a nutrition content claim } \\
\text { about dietary fibre }\end{array}$ & $\begin{array}{l}\text { General claim condition: a serving of the } \\
\text { food contains at least } 2 \mathrm{~g} \text { of dietary fibre } \\
\text { unless the claim is about low or reduced } \\
\text { dietary fibre } \\
\text { 'Good source': a serving of the food } \\
\text { contains at least } 4 \mathrm{~g} \text { of dietary fibre } \\
\text { Excellent source': a serving of the food } \\
\text { contains at least } 7 \mathrm{~g} \text { of dietary fibre } \\
\text { 'Increased': (a) the reference food contains } \\
\text { at least } 2 \mathrm{~g} \text { of dietary fibre per serving; } \\
\text { and (b) the food contains at least } 25 \% \\
\text { more dietary fibre than in the same } \\
\text { quantity of reference food }\end{array}$ & $\begin{array}{l}\text { Standard } 1.2 .7 \\
\text { Nutrition, Health and } \\
\text { Related claims; } \\
\text { Food Standards } \\
\text { Australia New } \\
\text { Zealand } 2013^{(5)}\end{array}$ \\
\hline
\end{tabular}

RACC, reference amounts customarily consumed.

Provides $10-19 \%$ of the Dietary Reference Value per RACC.

${ }^{2} 3 \mathrm{~g}$ or less per RACC and per $50 \mathrm{~g}$ if RACC is small; meals and main dishes: $3 \mathrm{~g}$ or less per $100 \mathrm{~g}$ and not more than $30 \%$ of energy from fat.

${ }^{3} 1 \mathrm{~g}$ or less per RACC and $15 \%$ or less of energy from saturated fat; meals and main dishes: $1 \mathrm{~g}$ or less per $100 \mathrm{~g}$ and less than $10 \%$ of energy from saturated fat.

${ }^{4} 20 \mathrm{mg}$ or less per RACC and per $50 \mathrm{~g}$ of food if RACC is small; meals and main dishes: $20 \mathrm{mg}$ or less per $100 \mathrm{~g}$.

${ }^{6}$ Provides at least $6 \mathrm{~g}$ of fibre per $100 \mathrm{~g}$ or at least $3 \mathrm{~g}$ of fibre per $100 \mathrm{kcal}(418 \mathrm{~kJ})$. 
Table 10. Potential recommendations for intake of specific fibres (subtypes of fibres) based on health claims

\begin{tabular}{|c|c|c|}
\hline Fibre type & Health effect & Recommended intake for health effect \\
\hline a-Cyclodextrin & Contributes to reduction of postprandial glycaemic response & $5 \mathrm{~g}$ a-cyclodextrin per $50 \mathrm{~g}$ of starch in the meal \\
\hline AX from wheat endosperm & Contribute to reduction of postprandial glycaemic response & $8 \mathrm{~g}$ of $\mathrm{AX}$ per $100 \mathrm{~g}$ available carbohydrate as part of a meal \\
\hline$\beta$-Glucans from oats or barley & Contributes to maintenance/reduction of normal blood cholesterol & Beneficial effect obtained with intake of $3 \mathrm{~g} \beta$-glucans $/ \mathrm{d}$ \\
\hline$\beta$-Glucans from oats or barley & Contributes to reduction of postprandial glycaemic response & $4 \mathrm{~g} \beta$-glucans per $30 \mathrm{~g}$ available carbohydrate in the meal \\
\hline Chitosan & Contributes to maintenance of normal blood cholesterol level & Beneficial effect obtained with intake of $3 \mathrm{~g}$ chitosan $/ \mathrm{d}$ \\
\hline Glucomannan & Contributes to maintenance of normal blood cholesterol level & $\begin{array}{l}\text { Beneficial effect obtained with intake of } 4 \mathrm{~g} \\
\text { glucomannan/d }\end{array}$ \\
\hline Glucomannan & Contributes to weight loss in an energy-restricted diet & $\begin{array}{l}\text { Beneficial effect obtained with intake of } 3 \mathrm{~g} \\
\text { glucomannan/d }\end{array}$ \\
\hline Guar gum & Contributes to maintenance of normal blood cholesterol level & Beneficial effect obtained with intake of $10 \mathrm{~g}$ guar gum $/ \mathrm{d}$ \\
\hline Pectins & Reduce postprandial glycaemic response & $\begin{array}{l}\text { Beneficial effect obtained with intake of } 10 \mathrm{~g} \text { as part of } \\
\text { the meal }\end{array}$ \\
\hline Pectins & Contribute to maintenance of normal blood cholesterol level & Beneficial effect obtained with intake of $6 \mathrm{~g}$ pectins/d \\
\hline Resistant starch & Contributes to a reduction in the blood glucose rise after that meal & $\begin{array}{l}\text { Beneficial effect obtained where at least } 14 \% \text { of total } \\
\text { starch has been replaced by resistant starch }\end{array}$ \\
\hline Wheat bran fibre & Reduces intestinal transit time & $\begin{array}{l}\text { Beneficial effect obtained with daily intake of } \geq 10 \mathrm{~g} \\
\text { wheat bran fibre (mainly cellulose and xylans) }\end{array}$ \\
\hline
\end{tabular}

AX, arabinoxylans.

there should be recommendations for intake of some subtypes of fibre, such as oats and barley fibres, which are rich in $\beta$-glucans (soluble fibres) or insoluble types like RS, cellulose, and arabinoxylans. In addition, diets containing fibre from fruit, vegetables and grains are said to be related to reduced risk of heart disease. The fibres contained in these foods are mainly pectin, cellulose, $\beta$-glucans, xylans and lignin. Likewise, extracted fibres such as chitosan, guar gum and glucomannan could be recommended based on their role in disease risk reduction. The claims for which a specific amount of a specified fibre is needed are highlighted in Table 10.

Almost all studies that form the scientific evidence for a cause-and-effect relationship for fibre-specific claims are performed with added fibre types or bran, and, in general, responses with fibre have been compared with a control without fibre addition. In most cases, the quantity of fibre necessary for each health effect is difficult to achieve through a normal diet and the only fibre types where it might be possible to ingest a sufficient amount for a health effect through foods with their naturally occurring fibre content would be the $\beta$-glucans from oats, and perhaps barley. Since wheat bran is a common food ingredient, it is also possible to eat the amount of wheat bran fibre necessary to obtain a health effect through a normal diet.

Fibre intakes and sources in Europe from surveys and large studies (Tables 11-17)

\section{Methods used to compile tables}

A search was made of all large surveys and studies which reported dietary fibre intake where dietary assessment was conducted using a complete method, in other words, one where all foods consumed were recorded, such as $24 \mathrm{~h}$ recall and prospective foods records. Studies using FFQ were not included. This was done because a difference in intake of fibrecontaining foods, particularly fruit and vegetables, has been seen when FFQ have been compared with complete methods, such as $24 \mathrm{~h}$ recalls or food diaries ${ }^{(32)}$. Even when energy and macronutrient values match quite well, there can be substantial differences in fruit and vegetable intake between FFQ and other methods, resulting in important differences in fibre intake. Many of the studies included were national surveys, the reports of which were obtained online from government agencies and were not part of the published literature in the form of refereed publications. The most recent survey located was used in each country. Most surveys were produced since 2000; a few earlier reports were included if a more recent one could not be found. Other large studies, with several hundred individuals or more, were also included. In order to put the European countries in a world context, studies from other countries were also included, such as from the USA, Canada, Japan, Australia and South America. Studies were reported separately for adults, older adults, and children of varying ages, approximately 13-18 years, 4-12 years and 1-4 years old. There was also one recent survey of infants aged 4-18 months from the UK. For each study or survey, the following items were tabulated: country, year of assessment, the group being studied or the type of study, such as a national survey, age range (or mean age if only this was available), number of subjects, dietary assessment method, total fibre intake for males, females, and for both, reference, year of publication and any comments about additional information. It was intended to record dietary fibre assessment method, but so few studies mentioned this that it was omitted, and it was assumed that all studies except those from the UK used the AOAC or Prosky method. For the UK studies, dietary fibre was reported as NSP and hence RO, RS and lignin are not included. Studies from Ireland used either NSP or had figures for both methods. Results were taken as presented in the publications obtained and no attempt was made to obtain raw data.

Those studies and surveys for which information on sources of dietary fibre were provided were additionally tabulated to document these sources. Data were separated for adults of all ages and children of all ages. For each study, country, year of assessment, the groups being studied, age, sex, number of participants, reference and year of publication were recorded as 
before. Total fibre intake was documented, and then sources listed. Publications varied in the detail with which they provided sources and in the sources they listed. Many foods were common to all studies, such as potatoes, fruit and vegetables, but the grain or cereal products varied considerably and some studies recorded total grain products only. Efforts were made to rationalise these to allow comparisons to be made. The following were tabulated if at least three studies reported it: bread, pasta, biscuits and pastry, breakfast cereals, other grains not listed elsewhere, savoury snacks, potatoes, vegetables, legumes, fruit, sugar and confectionery, soup, nuts and seeds, meat and fish dishes. From the grain products reported, a total 'grain products' was calculated and a total of the percentage fibre intake was also calculated. In many cases, items with small percentages were omitted, but often these could be added to existing groups and were noted as such.

\section{Results}

A total of twenty-nine studies were found with dietary fibre intakes for adults (Table 11), ten for older adults (Table 12), sixteen for children aged 13-18 years (Table 13), twenty for children 4-12 years (Table 14) and eleven for children 1-4 years (Table 15), providing data for nearly 140000 individuals. The National Health and Nutrition Examination Survey (NHANES) in the USA is reported every 2 years, and hence from 2000, six sets of results are available. Only the last two sets, 2007-2008 and 2009-2010, have been included for comparison with intakes from Europe. Many of the surveys provided data for both adults and children or for children of different ages. Except for young children, most studies reported results for both males and females separately but in some cases the numbers of the different sexes participating were not given and hence an average intake could not be calculated. Most studies reported results for children aged 1-4 years for both sexes together and hence this only has been tabulated. In the three surveys of young children where the sexes were reported separately, namely the Australian National Survey, the Swedish National Survey and National Health and Nutrition Examination Survey (NHANES), fibre intakes were similar for boys and girls.

The age range of the studies on adults ranged mainly from 18 to 65 years, but there was considerable variation between surveys in age ranges considered as adults or older adults. The survey in Poland reported intakes for the entire age range from very young children to the elderly and is included in the table for adults. Roughly $65 \%$ of the studies of adults used $24 \mathrm{~h}$ recall, often, but not always repeated. For children, prospective records were more common, used in roughly $60 \%$ of studies. These ranged from 2 to $12 \mathrm{~d}$ of record.

Dietary fibre intake in adult males ranged from 15 to $25 \mathrm{~g} / \mathrm{d}$, while for females the figures were 14 to $21 \mathrm{~g} / \mathrm{d}$. The lowest figures were for Canada and the USA and therefore, in general, intakes of fibre were higher in Europe than in North America. On average, intakes for adult males in Europe were from 18 to $24 \mathrm{~g} / \mathrm{d}$ and for females 16 to $20 \mathrm{~g} / \mathrm{d}$, with little variation from one European country to another. Figures were lower for the UK since these were measured as NSP, but if a conversion of $1 \mathrm{~g}$ $\mathrm{NSP}=1.33 \mathrm{~g}$ TDF is used, the intakes in the UK are similar to those in other European countries. This picture was similar for older males in Europe, with intakes ranging from 18 to $22 \mathrm{~g} / \mathrm{d}$; intakes were more varied for older females, which may relate to the age distribution of the cohort being studied since total food intake decreases with age in older age.

For the youngest age group (1-4 years), dietary fibre intake ranged from 8 to $12 \mathrm{~g} / \mathrm{d}$. It was slightly lower in the Italian study by Sette et al. ${ }^{(33)}$ but this age group was rather younger than the other studies. Intakes were higher in Australia than in other countries at $16 \cdot 1 \mathrm{~g} / \mathrm{d}$ on average for children aged $2-3$ years. The study of infants aged 4-18 months was from the UK and reported intakes of NSP of 6-7 g/d (about 8 to $9 \mathrm{~g} / \mathrm{d}$ as TDF), increasing with age. For children aged 4-12 years, the range in intakes was quite wide, from about 10 to $18 \mathrm{~g} / \mathrm{d}$ for boys and 8 to $18 \mathrm{~g} / \mathrm{d}$ for girls. Intakes in Australia were again greater than for all other studies, boys 4-8 years at $19 \cdot 2 \mathrm{~g} / \mathrm{d}$ and 9-13 years $23.9 \mathrm{~g} / \mathrm{d}$, and for girls, $18.0 \mathrm{~g} / \mathrm{d}$ for $4-8$ years and $20.7 \mathrm{~g} / \mathrm{d}$ for 9-13 years. The country with the lowest intake was Argentina where a study of 10- to 12-year-olds reported intakes of about $9 \mathrm{~g} / \mathrm{d}$. For Europe, intakes were very similar from country to country, with lower values in Ireland and the UK where they were reported as NSP, but similar if converted to TDF. A Danish study from the late 1990 s also had high intakes, at $22.2 \mathrm{~g} / \mathrm{d}$ for boys and $19.4 \mathrm{~g} / \mathrm{d}$ for girls. This may be explained by they being slightly older, with an average age of 12.5 years. Intakes of teenagers were largely similar to those of younger children, again with higher intakes in Australia. As for other ages, there were no obvious differences between areas of Europe, with intakes in countries like Spain and Italy being similar to those in Germany or Austria or Scandinavia.

\section{Comparison of recommendations and intakes}

As indicated above, recommendations for fibre intake for adults for most European countries and for countries like Australia, New Zealand and the USA are in the order of 30-35 g/d for men and $25-32 \mathrm{~g} / \mathrm{d}$ for women. Overall average intakes do not reach this level of intake for any country. No recent survey for adults in Australia was found, but the surveys in children suggested that intakes are higher than in other countries. The highest average intake shown was that for the National Nutrition Survey in Germany in 2005/2006 where average intake for men was $25 \mathrm{~g} / \mathrm{d}$ and for women $23 \mathrm{~g} / \mathrm{d}$. Similarly, average intake in Hungary in a recent national survey was $25.5 \mathrm{~g} / \mathrm{d}$ for men and $20.9 \mathrm{~g} / \mathrm{d}$ for women. Not far behind were the intakes in the national survey in Finland in 2007, FINDIET, where average intake for men was $23.7 \mathrm{~g} / \mathrm{d}$ and for women $20.7 \mathrm{~g} / \mathrm{d}$. Other countries were far behind with average intakes of around $20 \mathrm{~g} / \mathrm{d}$ for men and around $15 \mathrm{~g} / \mathrm{d}$ for women. Recommendations for older adults are somewhat lower than for adults, at around $20 \mathrm{~g} / \mathrm{d}$ for men and women. Most countries show average intakes quite close to such a recommendation, with many around $20 \mathrm{~g} / \mathrm{d}$ for men and $18-20 \mathrm{~g} / \mathrm{d}$ for women. A number of surveys show increased intakes with age, such as the National Diet and Nutrition Survey in the UK.

For children, recommendations vary quite markedly from country to country; for example, for those aged 10-12 years, France recommends $5+$ age, equivalent to $15-17 \mathrm{~g} / \mathrm{d}$, for Poland, $19 \mathrm{~g} / \mathrm{d}$, for Australia and New Zealand, $20 \mathrm{~g} / \mathrm{d}$ for girls 
Table 11. Dietary fibre (DF) intakes in adults

\begin{tabular}{|c|c|c|c|c|c|c|c|c|c|c|c|}
\hline Country & $\begin{array}{l}\text { Year diet } \\
\text { assessed }\end{array}$ & Group studied & Age (years) & Sex & $n$ & $\begin{array}{l}\text { Dietary assessment } \\
\text { method }\end{array}$ & $\begin{array}{l}\text { Total fibre } \\
\text { intake } \\
M(g / d)\end{array}$ & $\begin{array}{l}\text { Total fibre } \\
\text { intake } \mathrm{F}(\mathrm{g} / \mathrm{d})\end{array}$ & $\begin{array}{l}\text { Total fibre } \\
\text { intake } M+F \\
\text { (g/d) }\end{array}$ & Reference & Year \\
\hline Austria & 2008 & Austrian Nutrition Report & $19-65$ & $\mathrm{M}$ and $\mathrm{F}$ & 2123 & $24 \mathrm{~h}$ recall & 20 & 20 & 20 & Elmadfa $^{(146)}$ & 2009 \\
\hline Belgium & 2004 & $\begin{array}{l}\text { Belgian National Food } \\
\text { Consumption Survey }\end{array}$ & $15-59$ & $\mathrm{M}$ and $\mathrm{F}$ & $1546 \mathrm{M}, 1537 \mathrm{~F}$ & $2 \times 24 \mathrm{~h}$ recall & 19.5 & $15 \cdot 8$ & 17.7 & Lin et al..$^{(107)}$ & 2011 \\
\hline Canada & 2011 & $\begin{array}{l}\text { Validation of FFQ in } \\
\text { Newfoundland }\end{array}$ & $35-70$ & $\mathrm{M}$ and $\mathrm{F}$ & 195 & $2 \times 24 \mathrm{~h}$ recall & 16.5 & $14 \cdot 3$ & NA & Liu et al. ${ }^{(147)}$ & 2013 \\
\hline Denmark & $2003-2008$ & National Nutrition Survey & $18-64$ & $M$ and $F$ & $1569 \mathrm{M}, 1785 \mathrm{~F}$ & $7 \mathrm{~d}$ record & 22 & 20 & 21 & Pederesen et al.(148) & 2010 \\
\hline Finland & 2007 & FINDIET 2007 & $25-64$ & $M$ and $F$ & $730 \mathrm{M}, 846 \mathrm{~F}$ & $48 \mathrm{~h}$ recall & $23 \cdot 7$ & $20 \cdot 7$ & $22 \cdot 1$ & Pietinen et al ${ }^{(149)}$ & 2010 \\
\hline Finland & 2001 & Young Finns longitudinal study & $24-39$ & $\mathrm{M}$ and $\mathrm{F}$ & $466 \mathrm{M}, 571 \mathrm{~F}$ & $48 \mathrm{~h}$ recall & $21 \cdot 0$ & 17.7 & 19.2 & Mikkilä et al. ${ }^{(150)}$ & 2004 \\
\hline France & $2006-2007$ & $\begin{array}{l}\text { INCA-2 National Food } \\
\text { Consumption Survey }\end{array}$ & $18-54$ & $\mathrm{M}$ and $\mathrm{F}$ & $531 \mathrm{M}, 754 \mathrm{~F}$ & $7 \mathrm{~d}$ record & $18 \cdot 3$ & $15 \cdot 9$ & 16.9 & $\mathrm{AFSSA}^{(151)}$ & 2009 \\
\hline France & 1994-2002 & SU.VI.MAX study & Average $50+$ & $\mathrm{M}$ and $\mathrm{F}$ & 3313 & $24 \mathrm{~h}$ recall & NA & NA & 21 & Deschasaux et al. ${ }^{(152)}$ & 2014 \\
\hline Germany & 2005-2006 & National Nutrition Survey & $19-64$ & $\mathrm{M}$ and $\mathrm{F}$ & $6391 \mathrm{M}, 7722 \mathrm{~F}$ & $2 \times 24 \mathrm{~h}$ recall & 25 & 23 & 24 & $\begin{array}{l}\text { Max Rubner-Institut } \\
\text { Bundesforschungsinstitut } \\
\text { für Ernährung und } \\
\text { Lebensmittel }\end{array}$ & 2008 \\
\hline Hungary & 2009 & National Nutrition Survey & $19-60$ & $\mathrm{M}$ and $\mathrm{F}$ & $1090 \mathrm{M}, 1242 \mathrm{~F}$ & $3 \mathrm{~d}$ record & $25 \cdot 5$ & $20 \cdot 9$ & & Szeitz-Szabó et al. ${ }^{(154)}$ & 2011 \\
\hline Ireland & 1997-1999 & $\begin{array}{l}\text { North/South Ireland Food } \\
\text { Consumption Survey }\end{array}$ & $18-64$ & $\mathrm{M}$ and $\mathrm{F}$ & $662 \mathrm{M}, 717 \mathrm{~F}$ & $7 \mathrm{~d}$ diary & $\begin{array}{l}\text { DF: } 23 \cdot 2 \\
\text { NSP } 16 \cdot 7\end{array}$ & $\begin{array}{l}\text { DF: } 17 \cdot 4 \\
\text { NSP: } 13 \cdot 0\end{array}$ & $\begin{array}{l}\text { DF: } 20 \cdot 2 \\
\text { NSP: } 14 \cdot 8\end{array}$ & Galvin et al. ${ }^{(87)}$ & 2001 \\
\hline Ireland & 2008-2010 & Irish National Nutrition Survey & $18-64$ & $\mathrm{M}$ and $\mathrm{F}$ & $634 \mathrm{M}, 640 \mathrm{~F}$ & $4 \mathrm{~d}$ record & $21 \cdot 1$ & $17 \cdot 3$ & $19 \cdot 2$ & Flynn et al. & 2011 \\
\hline Italy & 2005-2006 & $\begin{array}{l}\text { National Food Consumption } \\
\text { Survey }\end{array}$ & $18-64$ & $\mathrm{M}$ and $\mathrm{F}$ & 2831 & $3 \mathrm{~d}$ record & $19 \cdot 6$ & 17.7 & - & Sette et al. ${ }^{(156)}$ & 2011 \\
\hline Japan & 1998 & Japanese Nutrition Survey & $15+$ & $\mathrm{M}$ and $\mathrm{F}$ & About 15000 & $\begin{array}{l}\text { Weighed household } \\
\text { calculated for } \\
\text { each individual }\end{array}$ & NA & NA & $15 \cdot 0$ & Nakaji et al. ${ }^{(157)}$ & 2002 \\
\hline Japan & 1997 & Aomori Nutrition Survey & Mean 51-52 & $\mathrm{M}$ and $\mathrm{F}$ & 198M, 378F & $1 \mathrm{~d}$ weighed & $18 \cdot 8$ & $18 \cdot 0$ & $18 \cdot 3$ & Fukuda et al. ${ }^{(158)}$ & 2007 \\
\hline Netherlands & 2000 & $\begin{array}{l}\text { Amsterdam Growth and Health } \\
\text { Longitudinal Study }\end{array}$ & 36 & $\mathrm{M}$ and $\mathrm{F}$ & 368 & Diet history interview & - & - & $28 \cdot 3$ & van de Laar et al. ${ }^{(159)}$ & 2012 \\
\hline Netherlands & 2007-2010 & $\begin{array}{l}\text { Dutch National Food } \\
\text { Consumption Survey }\end{array}$ & $19-69$ & $\mathrm{M}$ and $\mathrm{F}$ & 2106 & $2 \times 24 \mathrm{~h}$ recall & 22 & 18 & 20 & van Rossum et al. ${ }^{(160)}$ & 2011 \\
\hline Norway & 2002-2003 & $\begin{array}{l}\text { Subsample of Norwegian } \\
\text { Women and Cancer Study }\end{array}$ & Mean 52 & $\mathrm{~F}$ & 238 & $4 \times 24 \mathrm{~h}$ recall & NA & $19 \cdot 1$ & NA & Hjartaker et al..$^{(76)}$ & 2007 \\
\hline $\begin{array}{l}\text { Norway } \\
\text { Poland }\end{array}$ & $\begin{array}{l}2010-2011 \\
2000\end{array}$ & $\begin{array}{l}\text { National Survey - Norkost } 3 \\
\text { National Food Consumption } \\
\text { Survey }\end{array}$ & $\begin{array}{l}18-70 \\
0-96\end{array}$ & $\begin{array}{l}M \text { and } F \\
M \text { and } F\end{array}$ & $\begin{array}{l}862 \mathrm{M}, 925 \mathrm{~F} \\
3716\end{array}$ & $\begin{array}{l}2 \times 24 \mathrm{~h} \text { recall } \\
24 \mathrm{~h} \text { recall }\end{array}$ & $\begin{array}{l}26 \\
\text { NA }\end{array}$ & $\begin{array}{l}22 \\
\text { NA }\end{array}$ & $\begin{array}{l}24 \\
23 \cdot 4\end{array}$ & $\begin{array}{l}\text { Totland et al. }{ }^{(161)} \\
\text { Sekula et al. }{ }^{(162)}\end{array}$ & $\begin{array}{l}2012 \\
2005\end{array}$ \\
\hline Spain & $2002-2003$ & $\begin{array}{l}\text { Repeat study in Catalonia } \\
\text { (ENCAT) }\end{array}$ & $18-64$ & $\mathrm{M}$ and $\mathrm{F}$ & $718 \mathrm{M}, 895 \mathrm{~F}$ & $2 \times 24 \mathrm{~h}$ recall & $19 \cdot 2$ & $16 \cdot 9$ & $17 \cdot 9$ & Serra-Majem et al. ${ }^{(163)}$ & 2007 \\
\hline Sweden & 2010-2011 & $\begin{array}{l}\text { National Survey - Riksmaten } \\
\text { 2010-2011 }\end{array}$ & $18-80$ & $\mathrm{M}$ and $\mathrm{F}$ & 1797 & $4 \mathrm{~d}$ diary & $21 \cdot 0$ & 18.6 & $19 \cdot 6$ & Amcoff et al. ${ }^{(164)}$ & 2012 \\
\hline UK & 2009-2012 & $\begin{array}{l}\text { National Diet and Nutrition } \\
\text { Survey }\end{array}$ & $19-64$ & $\mathrm{M}$ and $\mathrm{F}$ & 1491 & $4 \mathrm{~d}$ record & 14.7 & $12 \cdot 8$ & $13 \cdot 6$ & $\begin{array}{l}\text { Public Health England \& } \\
\text { Food Standards } \\
\text { Agency }{ }^{(165)}\end{array}$ & 2014 \\
\hline UK & 1999 & $\begin{array}{l}\text { National Survey of Health and } \\
\text { Development }\end{array}$ & 53 & $\mathrm{M}$ and $\mathrm{F}$ & $562 \mathrm{M}, 691 \mathrm{~F}$ & $5 \mathrm{~d}$ record & 15.5 & $14 \cdot 3$ & 14.8 & Prynne et al. ${ }^{(166)}$ & 2010 \\
\hline USA & 2009-2010 & NHANES & $20+$ & $\mathrm{M}$ and $\mathrm{F}$ & $1856 \mathrm{M}, 2007 \mathrm{~F}$ & $2 \times 24 \mathrm{~h}$ recall & 19.1 & $15 \cdot 5$ & $17 \cdot 2$ & $\begin{array}{l}\text { United States Department } \\
\text { of Agriculture }\end{array}$ & 2014 \\
\hline USA & 2011-2012 & NHANES & $20+$ & $\mathrm{M}$ and $\mathrm{F}$ & $1638 \mathrm{M}, 1662 \mathrm{~F}$ & $2 \times 24 \mathrm{~h}$ recall & 20.5 & $16 \cdot 2$ & $18 \cdot 3$ & $\begin{array}{l}\text { US Food and Drug } \\
\text { Administration }\end{array}$ & 2015 \\
\hline
\end{tabular}

M, male; F, female; NA, not available; INCA-2, Individual and National Study on Food Consumption 2; AFSSA, Agence Française de Sécurité Sanitaire des Aliments (French Agency for Food Safety); SU.VI.MAX, SUpplémentation en VItamines et Minéraux Anti-oXydants; ENCAT, Evaluation of Nutritional Status in Catalonia; NHANES, National Health and Nutrition Examination Survey. 
and $24 \mathrm{~g} / \mathrm{d}$ for boys (for 9-13 years) and for the USA, $26 \mathrm{~g} / \mathrm{d}$ for girls and $31 \mathrm{~g} / \mathrm{d}$ for boys (for $9-13$ years). Other countries have no official recommendation for children. Hence it is difficult to say if recommendations are being met overall, although for most countries, intakes are lower than the recommendation, with few reaching an average intake of $20 \mathrm{~g} / \mathrm{d}$ for boys or $18 \mathrm{~g} / \mathrm{d}$ for girls. For teenagers, recommendations are similar or slightly higher than for younger children. The only countries which have recorded intakes close to the recommendations are Australia in a national survey of 14- to 16-year-olds, and in the EskiMo project in Germany, where the average intakes for boys were about $27 \mathrm{~g} / \mathrm{d}$ and for girls 21 and $24 \mathrm{~g} / \mathrm{d}$. These relatively high intakes were also seen in a study of 13- to 14-year-old sports club attenders in Chile. All other studies showed intakes of less than $20 \mathrm{~g} / \mathrm{d}$ for older children, substantially lower than the recommendations in most countries.

\section{Sources of dietary fibre}

There are relatively few publications which provide detail on the types of dietary fibre consumed, such as further chemical classification, for example as specific hexoses (glucose, galactose, fucose and/or rhamnose), pentoses (arabinose and/or xylose) and/or uronic acid polymers (galacturonic and/or glucuronic acids), or cellulose, hemicelluloses and pectins, etc. or separated by other characteristics, such as solubility. Those studies that are available with such information are older than the recent surveys where total intakes were reported. Some of the recent surveys provided food sources of fibre and these were therefore tabulated for comparison. The few studies that reported sources for older adults were similar to those for adults aged 18-64 years, and hence have been omitted.

Food sources of fibre are shown in Table 16 for adults and Table 17 for children. In adults, grain products were the largest source of fibre in all countries, providing from $32-33 \%$ of fibre intake in the USA and Spain to $48-49 \%$ in Ireland, the Netherlands and Sweden. Some countries provided greater breakdown of grain sources, and, in these, bread was the major source, ranging from 11 to $30 \%$ of total fibre, with much smaller contributions from breakfast cereals, from 5 to $8 \%$, biscuits and pastries, from 3 to $11 \%$, and pasta from 1 to $4 \%$. There were no studies with detailed breakdown of the contributions from grains from Italy where pasta may have contributed a higher proportion. Vegetables, potatoes and fruit were the next highest sources, but these varied considerably, vegetables contributing from 12 to $21 \%$ of fibre intake, potatoes from 6 to $19 \%$ and fruit from 8 to $23 \%$. These variations reflect climatic growing conditions and hence cultural norms across Europe, with cooler northern European countries tending to have greater contributions to fibre intake from potatoes and warmer southern countries greater from fruit. Other foods, such as confectionery, savoury snacks, soup, milk products and meat dishes made smaller contributions to fibre intakes.

In children, results varied markedly even for studies in the same country. Such was the case for Belgium where one study of toddlers in Antwerp showed grains contributing 58\% of fibre intake, including $38 \%$ from bread alone, while another of preschoolers in Flanders found $37 \%$ from all grain products. 
Table 13. Dietary fibre intake in children aged 13 to 18 years*

\begin{tabular}{|c|c|c|c|c|c|c|c|c|c|c|}
\hline Country & $\begin{array}{l}\text { Year diet } \\
\text { assessed }\end{array}$ & Group studied & Age (years) & $n$ & $\begin{array}{l}\text { Dietary assessment } \\
\text { method }\end{array}$ & $\begin{array}{l}\text { Total fibre intake } \\
M(g / d)\end{array}$ & $\begin{array}{l}\text { Total fibre intake } \\
F(g / d)\end{array}$ & $\begin{array}{l}\text { Total fibre intake } \\
M+F(g / d)\end{array}$ & Reference & Year \\
\hline Australia & 2007 & National Survey & $14-16$ & NA & $24 \mathrm{~h}$ recall & 27.5 & 21.5 & 24.6 & $\begin{array}{l}\text { Australian } \\
\text { Government } \\
\text { Department of } \\
\text { Health and } \\
\text { Ageing }^{(170)}\end{array}$ & 2012 \\
\hline Austria & 2008 & Austrian Nutrition Report & $13-15$ & 780 & $3 \mathrm{~d}$ record & 16 & 14 & NA & Elmadfa ${ }^{(146)}$ & 2009 \\
\hline Belgium & 2004 & $\begin{array}{l}\text { Belgian National Food } \\
\text { Consumption Survey }\end{array}$ & $15-18$ & $1546 \mathrm{M}, 1537 \mathrm{~F}$ & $2 \times 24 \mathrm{~h}$ recall & $17 \cdot 8$ & $15 \cdot 0$ & $16 \cdot 7$ & Lin et al..$^{(107)}$ & 2011 \\
\hline Chile & Not given & $\begin{array}{l}\text { Regular attenders of sports } \\
\text { clubs }\end{array}$ & $11-14$ & 105 & $24 \mathrm{~h}$ recall & NA & NA & $\begin{array}{l}13 \text { years: } 27 \cdot 1 \\
14 \text { years: } 23 \cdot 2\end{array}$ & Liberona et al. ${ }^{(171)}$ & 2010 \\
\hline Denmark & 2005-2008 & $\begin{array}{l}\text { National Survey of Dietary } \\
\text { Habits and Physical } \\
\text { Activity }\end{array}$ & $14-17$ & $101 \mathrm{M}, 134 \mathrm{~F}$ & $7 \mathrm{~d}$ record & 19 & 16 & 18 & Pedersen et al. ${ }^{(148)}$ & 2010 \\
\hline Finland & 2007 & $\begin{array}{l}\text { School-based study around } \\
\text { Finland }\end{array}$ & 13.8 average & $136 \mathrm{M}, 170 \mathrm{~F}$ & $48 \mathrm{~h}$ recall & $16 \cdot 9$ & $16 \cdot 6$ & $16 \cdot 4$ & Hoppu et al. ${ }^{(172)}$ & 2010 \\
\hline France & 2006-2007 & INCA-2 & $11-17$ & $880 \mathrm{M}$ and $\mathrm{F}$ & $7 d$ record & $\begin{array}{l}11-14 \text { years } 14 \cdot 8 \\
15-17 \text { years: } 15 \cdot 2\end{array}$ & $\begin{array}{l}11-14 \text { years: } 12 \cdot 7 \\
15-17 \text { years: } 13 \cdot 3\end{array}$ & $\begin{array}{l}11-14 \text { years: } 13 \cdot 7 \\
15-17 \text { years } 14 \cdot 2\end{array}$ & $\mathrm{AFSSA}^{(151)}$ & 2009 \\
\hline Germany & 2006 & $\begin{array}{l}\text { EsKiMo - part of healthy } \\
\text { eating project }\end{array}$ & $6-17$ & 1272 & $3 \mathrm{~d}$ record & 27 & & NA & Stahl et al. ${ }^{(173)}$ & 2009 \\
\hline $\begin{array}{l}\text { Ireland } \\
\text { Italy }\end{array}$ & $\begin{array}{l}2004-2005 \\
2005-2006\end{array}$ & $\begin{array}{l}\text { National Teen's Food Survey } \\
\text { National Food Consumption } \\
\text { Survey }\end{array}$ & $\begin{array}{l}13-17 \\
4-17\end{array}$ & $\begin{array}{l}224 \mathrm{M}, 217 \mathrm{~F} \\
492\end{array}$ & $\begin{array}{l}7 \mathrm{~d} \text { record } \\
3 \mathrm{~d} \text { record }\end{array}$ & $\begin{array}{l}13.1 \\
10-17 \text { years: } 18 \cdot 1\end{array}$ & $\begin{array}{l}10 \cdot 1 \\
10-17 \text { years: } 16 \cdot 4\end{array}$ & $\begin{array}{l}11.6 \\
3-9 \text { years: } 14.4\end{array}$ & $\begin{array}{l}\text { Flynn et al. } .^{(155)} \\
\text { Sette et al. }{ }^{(156)}\end{array}$ & $\begin{array}{l}2011 \\
2011\end{array}$ \\
\hline $\begin{array}{l}\text { Italy } \\
\text { Netherlands }\end{array}$ & $\begin{array}{l}2000-2001 \\
2007-2010\end{array}$ & $\begin{array}{l}\text { Schoolchildren in Rome } \\
\text { Dutch National Nutrition } \\
\text { Survey }\end{array}$ & $\begin{array}{l}\text { Mean } 17 \\
7-18\end{array}$ & $\begin{array}{l}125 \mathrm{M}, 108 \mathrm{~F} \\
1713\end{array}$ & $\begin{array}{l}12 \mathrm{~d} \text { record } \\
2 \times 24 \mathrm{~h} \text { recall }\end{array}$ & $\begin{array}{l}17 \\
18 \cdot 5\end{array}$ & $\begin{array}{l}14 \\
16 \cdot 2\end{array}$ & $\begin{array}{l}15 \cdot 6 \\
17 \cdot 4\end{array}$ & $\begin{array}{l}\text { Leclercq et al. }{ }^{(174)} \\
\text { van Rossum } \\
\text { et al. }{ }^{(160)}\end{array}$ & $\begin{array}{l}2004 \\
2011\end{array}$ \\
\hline Norway & 2000 & National Survey & $8-14$ & $896 \mathrm{M}, 928 \mathrm{~F}$ & & $16 \cdot 0$ & $13 \cdot 8$ & 14.9 & $\begin{array}{l}\text { Overby \& Frost } \\
\text { Anderson }{ }^{(175)}\end{array}$ & 2002 \\
\hline Spain & 2002-2003 & $\begin{array}{l}\text { Repeat study in Catalonia } \\
\text { (ENCAT) }\end{array}$ & $10-17$ & $114 \mathrm{M}, 89 \mathrm{~F}$ & $2 \times 24 \mathrm{~h}$ recall & $18 \cdot 7$ & $17 \cdot 4$ & $18 \cdot 1$ & $\begin{array}{l}\text { Serra-Majem } \\
\text { et al. } \text {.163) }^{163)}\end{array}$ & 2007 \\
\hline UK & 2009-2012 & $\begin{array}{l}\text { National Diet and Nutrition } \\
\text { Survey }\end{array}$ & $11-18$ & $744 \mathrm{M}, 753 \mathrm{~F}$ & $4 \mathrm{~d}$ record & $12 \cdot 8$ & $10 \cdot 7$ & $11 \cdot 8$ & $\begin{array}{l}\text { Public Health } \\
\text { England \& Food } \\
\text { Standards } \\
\text { Agency }^{(165)}\end{array}$ & 2014 \\
\hline USA & 2009-2010 & NHANES & $12-19$ & $672 \mathrm{M}, 593 \mathrm{~F}$ & $2 \times 24 \mathrm{~h}$ recall & $16 \cdot 4$ & $12 \cdot 6$ & $14 \cdot 6$ & $\begin{array}{l}\text { United States } \\
\text { Department of } \\
\text { Agriculture }\end{array}$ & 2014 \\
\hline USA & 2011-2012 & NHANES & $12-19$ & $585 \mathrm{M}, 567 \mathrm{~F}$ & $2 \times 24 \mathrm{~h}$ recall & $18 \cdot 1$ & 12.5 & $15 \cdot 3$ & $\begin{array}{l}\text { US Food and Drug } \\
\text { Administration }{ }^{(30)}\end{array}$ & 2015 \\
\hline
\end{tabular}

M, male; F, female; NA, not available; INCA-2, Individual and National Study on Food Consumption 2; AFSSA, Agence Française de Sécurité Sanitaire des Aliments (French Agency for Food Safety); ENCAT, Evaluation of Nutritional Status in Catalonia; NHANES, National Health and Nutrition Examination Survey.

* All studies included both males and females. 
Table 14. Dietary fibre intake in children aged 4 to 12 years*

\begin{tabular}{|c|c|c|c|c|c|c|c|c|c|c|}
\hline Country & $\begin{array}{l}\text { Year diet } \\
\text { assessed }\end{array}$ & Group studied & Age (years) & $n$ & $\begin{array}{l}\text { Dietary assessment } \\
\text { method }\end{array}$ & $\begin{array}{l}\text { Total fibre intake } \\
M(g / d)\end{array}$ & $\begin{array}{l}\text { Total fibre intake } \\
F(\mathrm{~g} / \mathrm{d})\end{array}$ & $\begin{array}{l}\text { Total fibre intake } \\
M+F(g / d)\end{array}$ & Reference & Year \\
\hline Argentina & 2005 & $\begin{array}{l}\text { School-aged children in } \\
\text { Buenos Aires }\end{array}$ & $10-12$ & 1588 & $24 \mathrm{~h}$ recall & $9 \cdot 6$ & 8.5 & - & Kovalskys et al. ${ }^{(176)}$ & 2013 \\
\hline Australia & 2007 & National Survey & $4-8 ; 9-13$ & & $24 \mathrm{~h}$ recall & $\begin{array}{l}4-8 \text { years: } 19.2 \\
9-13 \text { years: } 23 \cdot 9\end{array}$ & $\begin{array}{l}4-8 \text { years: } 18 \cdot 0 \\
9-13 \text { years: } 20 \cdot 7\end{array}$ & $\begin{array}{l}4-8 \text { years: } 18 \cdot 6 \\
9-13 \text { years: } 22 \cdot 3\end{array}$ & $\begin{array}{l}\text { Australian Government } \\
\text { Department of Health } \\
\text { and Ageing }{ }^{(170)}\end{array}$ & 2012 \\
\hline Austria & 2008 & Austrian Nutrition Report & $7-13$ & 780 & $3 \mathrm{~d}$ record & $\begin{array}{l}7-10 \text { years: } 15 \\
10-13 \text { years: } 15\end{array}$ & $\begin{array}{l}7-10 \text { years: } 14 \\
10-13 \text { years } 14\end{array}$ & NA & Elmadfa $^{(146)}$ & 2009 \\
\hline Belgium & 2002-2003 & $\begin{array}{l}\text { Flanders preschool dietary } \\
\text { survey }\end{array}$ & $2 \cdot 5-6 \cdot 5$ & 661 & 3d diary & $13 \cdot 9$ & $12 \cdot 9$ & NA & Lin et $a l^{(177)}$ & 2011 \\
\hline Chile & Not given & $\begin{array}{l}\text { Regular attenders of sports } \\
\text { clubs }\end{array}$ & $11-12$ & 105 & $24 \mathrm{~h}$ recall & NA & NA & $\begin{array}{l}11 \text { years: } 22 \cdot 9 \\
12 \text { years: } 21 \cdot 2\end{array}$ & Liberona et al. ${ }^{(171)}$ & 2010 \\
\hline Denmark & 1997-1998 & $\begin{array}{l}\text { Danish arm of European } \\
\text { Youth Heart Studies }\end{array}$ & $12-12 \cdot 5$ & 651 & $24 \mathrm{~h}$ recall & $22 \cdot 2$ & $19 \cdot 4$ & 20.7 & Kynde et al. ${ }^{(178)}$ & 2010 \\
\hline Denmark & 2005-2008 & $\begin{array}{l}\text { National Survey of Dietary } \\
\text { Habits and Physical } \\
\text { Activity }\end{array}$ & $4-13$ & $417 \mathrm{M}, 425 \mathrm{~F}$ & $7 \mathrm{~d}$ record & $18 \cdot 3$ & $16 \cdot 4$ & 17 & Pedersen et al. ${ }^{(148)}$ & 2010 \\
\hline Finland & 2003-2005 & $\begin{array}{l}\text { Diabetes Prediction and } \\
\text { Prevention Project }\end{array}$ & $4-6$ & 1267 & $3 \mathrm{~d}$ record & NA & NA & $13 \cdot 5$ & Kyttälä et al. ${ }^{(179)}$ & 2010 \\
\hline France & 2006-2007 & INCA-2 & $3-10$ & 575 & $7 \mathrm{~d}$ record & 11.8 & 11.0 & 11.4 & AFSSA $^{(151)}$ & 2009 \\
\hline Germany & 2006 & $\begin{array}{l}\text { EsKiMo - healthy eating } \\
\text { project }\end{array}$ & $6-11$ & 1234 & $3 \mathrm{~d}$ record & 17 & 16 & $17 \cdot 4$ & Stahl et al. ${ }^{(173)}$ & 2009 \\
\hline $\begin{array}{l}\text { Germany } \\
\text { Greece }\end{array}$ & $\begin{array}{l}\text { 1992-2007 } \\
\text { Not given }\end{array}$ & $\begin{array}{l}\text { DONALD study, Dortmund } \\
\text { Children on two islands, } \\
\text { Samos and Corfu }\end{array}$ & $\begin{array}{l}7 \\
3-12\end{array}$ & $\begin{array}{l}380 \\
248\end{array}$ & $\begin{array}{l}3 \mathrm{~d} \text { weighed record } \\
3 \mathrm{~d} \text { recall }\end{array}$ & $\begin{array}{l}\text { NA } \\
\text { NA }\end{array}$ & $\begin{array}{l}\text { NA } \\
\text { NA }\end{array}$ & $\begin{array}{l}16 \cdot 2 \\
\text { 3-6 years: } 12 \cdot 8 \\
7-12 \text { years: } 14 \cdot 8\end{array}$ & $\begin{array}{l}\text { Buyken et al. }{ }^{(180)} \\
\text { Grammatikopoulou } \\
\text { et al. }{ }^{(181)}\end{array}$ & $\begin{array}{l}2008 \\
2008\end{array}$ \\
\hline Ireland & 2003-2004 & $\begin{array}{l}\text { Irish National Children's } \\
\text { Food Survey }\end{array}$ & $5-12$ & 293M, 301F & $7 \mathrm{~d}$ record & $10 \cdot 0$ & 8.8 & 9.4 & IUNA ${ }^{(168)}$ & 2011 \\
\hline Italy & 2005-2006 & $\begin{array}{l}\text { National Food Consumption } \\
\text { Survey }\end{array}$ & $4-17$ & 492 & $3 \mathrm{~d}$ record & $10-17$ years: 18.1 & $10-17$ years: $16 \cdot 4$ & $3-9$ years: 14.4 & Sette et al. ${ }^{(156)}$ & 2011 \\
\hline Netherlands & $2007-2010$ & $\begin{array}{l}\text { Dutch National Nutrition } \\
\text { Survey }\end{array}$ & $7-18$ & 1713 & $2 \times 24 \mathrm{~h}$ recall & $18 \cdot 5$ & $16 \cdot 2$ & $17 \cdot 4$ & van Rossum et al. ${ }^{(160)}$ & 2011 \\
\hline Norway & 2000 & National Survey & $8-14$ & $896 \mathrm{M}, 928 \mathrm{~F}$ & $\begin{array}{l}4 \mathrm{~d} \text { food record and } \\
\text { FFQ }\end{array}$ & $16 \cdot 0$ & $13 \cdot 8$ & $14 \cdot 9$ & $\begin{array}{l}\text { Overby \& Frost } \\
\text { Anderson }^{(175)}\end{array}$ & 2002 \\
\hline Spain & 2002-2003 & $\begin{array}{l}\text { Repeat study in Catalonia } \\
\text { (ENCAT) }\end{array}$ & $10-17$ & $114 \mathrm{M}, 89 \mathrm{~F}$ & $2 \times 24 \mathrm{~h}$ recall & $18 \cdot 7$ & $17 \cdot 4$ & $18 \cdot 1$ & Serra-Majem et al. ${ }^{(163)}$ & 2007 \\
\hline Sweden & 2003 & National Food Survey & $\begin{array}{l}\text { Grades } 2 \\
\text { and } 5\end{array}$ & $\begin{array}{l}889 \text { grade } 2 \\
1016 \text { grade } 5\end{array}$ & $4 \mathrm{~d}$ diary & $\begin{array}{l}\text { Grade 2: } 14 \\
\text { Grade 5: } 13\end{array}$ & $\begin{array}{l}\text { Grade 2: } 13 \\
\text { Grade 5: } 12\end{array}$ & $\begin{array}{l}\text { Grade 2: } 13 \\
\text { Grade 5: } 13\end{array}$ & $\begin{array}{l}\text { Enghardt Barbieri } \\
\text { et al. }\end{array}$ & 2006 \\
\hline Sweden & 2003 & National survey of children & 4 & 590 & $4 \mathrm{~d}$ record & NA & NA & 11 & $\begin{array}{l}\text { Enghardt Barbieri } \\
\text { et al. }{ }^{(182)}\end{array}$ & 2006 \\
\hline UK & 2009-2012 & $\begin{array}{l}\text { National Diet and Nutrition } \\
\text { Survey }\end{array}$ & $4-10$ & $665 \mathrm{M}, 612 \mathrm{~F}$ & $4 \mathrm{~d}$ record & 11.5 & $10 \cdot 7$ & $11 \cdot 1$ & $\begin{array}{l}\text { Public Health England \& } \\
\text { Food Standards } \\
\text { Agency } 1(165)\end{array}$ & 2014 \\
\hline USA & 2009-2010 & NHANES & $6-11$ & $588 \mathrm{M}, 566 \mathrm{~F}$ & $2 \times 24 \mathrm{~h}$ recall & $13 \cdot 6$ & 14.5 & $14 \cdot 0$ & $\begin{array}{l}\text { United States } \\
\text { Department of } \\
\text { Agriculture }^{(167)}\end{array}$ & 2014 \\
\hline USA & 2011-2012 & NHANES & $6-11$ & $590 \mathrm{M}, 556 \mathrm{~F}$ & $2 \times 24 \mathrm{~h}$ recall & $15 \cdot 4$ & $13 \cdot 9$ & $14 \cdot 7$ & $\begin{array}{l}\text { US Food and Drug } \\
\text { Administration }\end{array}$ & 2015 \\
\hline
\end{tabular}

M, male; F, female; NA, not available; INCA-2, Individual and National Study on Food Consumption 2; AFSSA, Agence Française de Sécurité Sanitaire des Aliments (French Agency for Food Safety); DONALD, Dortmund Nutritional and

Anthropometric Longitudinally Designed; ENCAT, Evaluation of Nutritional Status in Catalonia; NHANES, National Health and Nutrition Examination Survey. 
Table 15. Dietary fibre intake in young children aged 0 to 4 years*

\begin{tabular}{|c|c|c|c|c|c|c|c|c|}
\hline Country & $\begin{array}{l}\text { Year diet } \\
\text { assessed }\end{array}$ & Group studied & Age (years) & $n$ & $\begin{array}{l}\text { Dietary assessment } \\
\text { method }\end{array}$ & $\begin{array}{l}\text { Total fibre intake } \\
(\mathrm{g} / \mathrm{d})\end{array}$ & Reference & Year \\
\hline Australia & 2007 & $\begin{array}{l}\text { National Survey of } \\
\text { Children }\end{array}$ & $2-3$ & NA & $24 \mathrm{~h}$ recall & $16 \cdot 1$ & $\begin{array}{l}\text { Australian Government } \\
\text { Department of Health } \\
\text { and Ageing }(170)\end{array}$ & 2012 \\
\hline Australia & $2005-2007$ & $\begin{array}{l}\text { Preschool children in } \\
\text { Adelaide }\end{array}$ & $1-5$ & 297 & $3 d$ record & $10 \cdot 7$ & Zhou et al. ${ }^{(183)}$ & 2012 \\
\hline Belgium & 1999-2000 & Toddlers in Antwerp & $2-3$ & 115 & $7 \mathrm{~d}$ weighed & $10 \cdot 9$ & Bosscher et al. ${ }^{(184)}$ & 2002 \\
\hline Finland & $2003-2005$ & $\begin{array}{l}\text { Diabetes Prediction } \\
\text { Prevention Project }\end{array}$ & $1-3$ & 1156 & $3 \mathrm{~d}$ record & $10 \cdot 5$ & Kyttälä et al. ${ }^{(179)}$ & 2010 \\
\hline Ireland & 2010-2011 & $\begin{array}{l}\text { National Pre-School } \\
\text { Nutrition Survey }\end{array}$ & $1-5$ & 500 & $4 \mathrm{~d}$ record & 11.9 & IUNA $^{(168)}$ & 2012 \\
\hline Italy & 2005-2006 & $\begin{array}{l}\text { National Food } \\
\text { Consumption Survey }\end{array}$ & $0-3$ & 492 & $3 \mathrm{~d}$ record & $8 \cdot 2$ & Sette et al. ${ }^{(156)}$ & 2011 \\
\hline Netherlands & $2011-2013$ & Study of Dutch children & $1-3$ & 1016 & $2 \mathrm{~d}$ record & $12 \cdot 5$ & Gubbels et al. ${ }^{(185)}$ & 2014 \\
\hline UK & 2009-2012 & NDNS & $1 \cdot 5-3$ & 604 & $4 \mathrm{~d}$ record & $8 \cdot 2$ & $\begin{array}{l}\text { Public Health England \& } \\
\text { Food Standards } \\
\text { Agency }{ }^{(165)}\end{array}$ & 2014 \\
\hline USA & 2009-2010 & NHANES & $2-5$ & 861 & $2 \times 24 \mathrm{~h}$ recall & $11 \cdot 7$ & $\begin{array}{l}\text { United States Department } \\
\text { of Agriculture }{ }^{(167)}\end{array}$ & 2014 \\
\hline USA & $2011-2012$ & NHANES & $2-5$ & 834 & $2 \times 24 \mathrm{~h}$ recall & $12 \cdot 1$ & $\begin{array}{l}\text { US Food and Drug } \\
\text { Administration } \\
(30)\end{array}$ & 2015 \\
\hline \multicolumn{9}{|c|}{ Children less than 18 months } \\
\hline UK & 2011 & $\begin{array}{l}\text { Diet and Nutrition } \\
\text { Survey of Infants and } \\
\text { Young Children }\end{array}$ & 4-18 months & 2683 & $4 \mathrm{~d}$ record & $\begin{array}{l}4-6 \text { months: } 4 \cdot 6 \\
7-9 \text { months: } 6 \cdot 3 \\
\text { 10-11 months: } 7 \cdot 2 \\
12-18 \text { months: } 7 \cdot 3\end{array}$ & Lennox et al. ${ }^{(186)}$ & 2014 \\
\hline
\end{tabular}

NA, not available; NDNS, National Diet and Nutrition Survey; NHANES, National Health and Nutrition Examination Survey.

* All studies included both males and females.

A report of the National Health and Nutrition Examination Survey (NHANES) for 2003-2006 indicated that grains provided $44 \%$ of fibre intake, while another of $2009-2010$ found $33 \%$. As in adults, grains were again the major source of fibre but, with such varied figures, there must be considerable variation in how the food sources are calculated and it is difficult to give precise figures. Fruit appeared to make a greater contribution to fibre for children than for adults, with values ranging from below $10 \%$ for older children in the UK to $26 \%$ for children in Spain. The UK had the lowest fruit contribution compared with other European countries. Both in the UK and Australia where detailed information was provided for different age groups of children, there was a decreasing contribution to fibre intake from fruit with age, with lowest values in teenagers.

\section{Intakes of fibre components}

There are very few publications, particularly recent ones, which describe intake of dietary fibre components, as compared with total fibre. A small number of studies have reported RS intakes, as shown in Table 18, although these cannot capture RS3 which is mostly produced by home preparation and storage conditions. The information that can be obtained suggests, as shown in the Table, that many European countries are likely to have intakes of RS of about $4-5 \mathrm{~g} / \mathrm{d}$, with more where there are high intakes of pasta as in Italy. Asian countries like China have much higher intakes of about $15 \mathrm{~g} / \mathrm{d}$. By far the largest proportion of the RS comes from grain products for all the countries studied, and as expected the source of grain products varied with the type of food consumed in large amounts, such as pasta in Italy or rice in Asia.
Only four studies, three of them small, could be located which reported lignin intake using complete dietary assessment methods, not food frequency, and were all from the 1970s. They suggested that lignin intake was in the order of $1-3 \mathrm{~g} / \mathrm{d}$ in Western countries.

\section{Dietary fibre and health}

This section summarises the evidence relating dietary fibre and specifically different types or sources of fibre to health, with the goal of establishing whether there is sufficient evidence to provide more detailed advice to the public on types or sources to consume based on the effects different types may have against certain health conditions. Systematic reviews were not conducted specifically for this paper, but the evidence presented is largely taken from existing systematic reviews, some of these prepared recently for the SACN review of carbohydrates, published in June $2015^{(34)}$.

Relationship between dietary fibre intake, fibre types and sources of fibre and risk of chronic non-communicable diseases

Since the early work of Dennis Burkitt and Hugh Trowell in the $1970 s^{(35)}$, it has been recognised that diets which are low in dietary fibre content are associated with poorer health. The history of interest in the health aspects of dietary fibre has gone through a number of phases, starting with exploration of impact on colonic function and short-term effects on glycaemia and regulation of blood cholesterol. More recently, associations with hard endpoints such as cancers and CVD events have been 


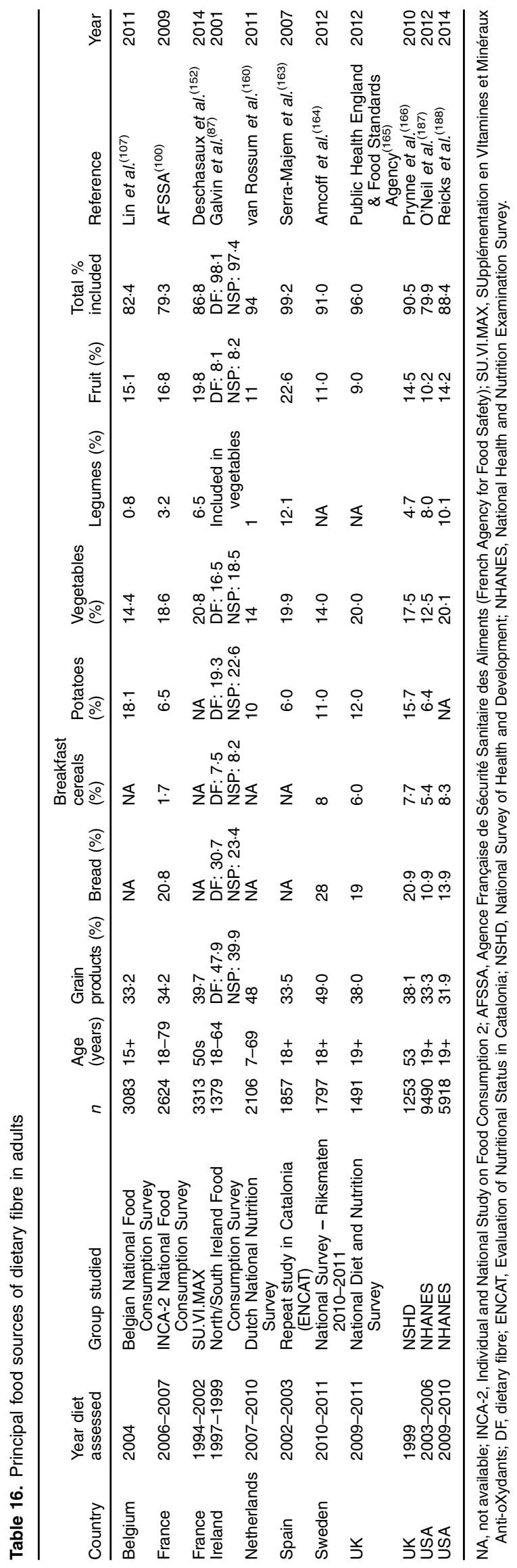

explored using data from maturing prospective cohort studies. Whilst the body of evidence from these latter studies has increased markedly in the past decade, few analyses of the relative impact of the sources of dietary fibre have been conducted. Mostly, where these have been undertaken, the sources have included vegetable, fruit and cereal sources of dietary fibre and more rarely legume fibre and nuts and seeds fibre. In addition, within the cereal fibre sources, the fibre fractions will vary markedly depending on the dominant grain type consumed (oats, wheat, rye, etc.) due to their differing composition. This variation in grain type may be at the heart of some of the differences between studies in terms of risk association with cereal fibre from country to country, since the staple grain consumed varies markedly by geographical region.

\section{Methods used to compile tables}

Due to the huge amount of scientific literature, this paper assessed the current situation using reviews, pooled analyses and latest results from the European Prospective Investigation into Cancer and Nutrition (EPIC) if they have not been integrated into an existing meta-analysis. For cancer outcomes, the 2007 report for the World Cancer Research Fund (WCRF) ${ }^{(36)}$ and WCRF Continuous Update Project ${ }^{(37)}$ were used as the primary source of information. For cardiometabolic outcomes, the UK SACN Carbohydrates and Health report (2015) was the primary source ${ }^{(34)}$. Priority was given to meta-analyses of randomised controlled trials and prospective cohort studies over case-control studies, except for outcomes where no other evidence exists.

A search was made using PubMed using the following search terms: systematic review, meta-analysis, dietary fiber, dietary fibre, cereal fibre, vegetable fibre, fruit fibre, legume fibre, EPIC, European Prospective Investigation into Cancer. Only papers in English and published in the last decade were used.

\section{Results}

Table 19 lists the results, where available, of the most recent dose-response meta-analyses identified of dietary fibre, dietary fibre sources and disease outcomes. For further detail of the methodology of dose-response meta-analyses, please refer to Berlin et $a l .{ }^{(38)}$. The pooled estimate of risk for each disease outcome was represented for each incremental unit consumed, along with the $95 \% \mathrm{CI}$ around that estimate. The latter provides an indication of the statistical significance of the pooled risk estimate. It can be seen that none of the pooled estimates indicates a positive association, that is, all suggest either a lack of association (risk estimate close to unity) or a negative association (increasing consumption of dietary fibre or fibre source is associated with a lowering of risk, risk estimates markedly less than unity). Accordingly, where a statistically significant negative association has been reported, this has been indicated (*) to permit identification of any pattern around the relative associations by disease outcome and fibre source. Meta-analyses in which pooled estimates are derived comparing risk in the highest category of consumers with those in the lowest are also discussed in the text, but these estimates are not included in Table 19. Compared with the dose-response meta-analysis, this approach 
Table 17. Principal food sources of dietary fibre in children

\begin{tabular}{|c|c|c|c|c|c|c|c|c|c|c|c|c|c|c|c|}
\hline Country & $\begin{array}{l}\text { Year diet } \\
\text { assessed }\end{array}$ & Group studied & Age (years) & $n$ & $\begin{array}{l}\text { Grain } \\
\text { products (\%) }\end{array}$ & Bread (\%) & Pasta (\%) & $\begin{array}{l}\text { Breakfast } \\
\text { cereals (\%) }\end{array}$ & Potatoes (\%) & $\begin{array}{l}\text { Vegetables } \\
(\%)\end{array}$ & Legumes $(\%)$ & Fruit (\%) & $\begin{array}{l}\text { Total of what } \\
\text { provided (\%) }\end{array}$ & Reference & Year \\
\hline Australia & 2007 & $\begin{array}{l}\text { Children's Nutrition } \\
\text { and Physical } \\
\text { Activity Survey }\end{array}$ & $\begin{array}{c}2-3 ; 4-8 ; \\
9-13 \\
14-16\end{array}$ & & $\begin{array}{l}\text { 2-3 years: } \\
40.1 ; 4-8 \\
\text { years: } \\
43 \cdot 5 ; 9-13 \\
\text { years: } \\
41 \cdot 8 ; 14- \\
16 \text { years } \\
40.5\end{array}$ & $\begin{array}{l}\text { 2-3 years: } \\
17.7 ; 4-8 \\
\text { years: } \\
19 \cdot 6 ; 9-13 \\
\text { years: } \\
16 \cdot 5 ; 14- \\
16 \text { years } \\
17.0\end{array}$ & $\begin{array}{c}2-3 \text { years: } \\
4.8 ; 4-8 \\
\text { years: } 5 \cdot 3 \\
9-13 \\
\text { years: } 5 \cdot 0 ; \\
14-16 \\
\text { years } 5 \cdot 0\end{array}$ & $\begin{array}{c}\text { 2-3 years: } \\
\text { 9.7; 4-8 } \\
\text { years: } 9.0 ; \\
9-13 \\
\text { years: } 8.6 ; \\
14-16 \\
\text { years } 8.9\end{array}$ & $\begin{array}{c}\text { 2-3 years: } \\
\text { 4.2; 4-8 } \\
\text { years: } 5 \cdot 6 \\
9-13 \\
\text { years: } 7 \cdot 0 ; \\
14-16 \\
\text { years } 8 \cdot 0\end{array}$ & $\begin{array}{c}\text { 2-3 years: } \\
\text { 12.8; } 4-8 \\
\text { years: } \\
11 \cdot 0 ; 9-13 \\
\text { years: } \\
12 \cdot 1 ; 14- \\
16 \text { years } \\
13 \cdot 3\end{array}$ & $\begin{array}{c}2-3 \text { years: } \\
2.0 ; 4-8 \\
\text { years: } 2 \cdot 1 \text {; } \\
9-13 \\
\text { years: } 1 \cdot 4 \\
14-16 \\
\text { years } 2 \cdot 1\end{array}$ & $\begin{array}{l}\text { 2-3 years: } \\
\text { 24.2; } 4-8 \\
\text { years: } \\
19 \cdot 8 ; 9-13 \\
\text { years: } \\
15 \cdot 1 ; 14- \\
16 \text { years } \\
11.9\end{array}$ & $\begin{array}{c}\text { 2-3 years: } \\
\text { 91.0; } 4-8 \\
\text { years: } \\
91.0 ; 9- \\
13 \text { years: } \\
92.9 ; 14- \\
16 \text { years } \\
89.0\end{array}$ & $\begin{array}{l}\text { Australian } \\
\text { Government } \\
\text { Department of } \\
\text { Health and } \\
\text { Ageing }^{(170)}\end{array}$ & 2012 \\
\hline Belgium & 2002-2003 & $\begin{array}{l}\text { Flanders preschool } \\
\text { dietary survey }\end{array}$ & $2 \cdot 5-6 \cdot 5$ & 661 & 37.4 & 27.5 & 1.0 & $2 \cdot 0$ & 17.6 & 11.8 & NA & $17 \cdot 8$ & $98 \cdot 0$ & Lin et al. (107) & 2011 \\
\hline Belgium & 1999-2000 & $\begin{array}{l}\text { Study of toddlers } \\
\text { in Antwerp }\end{array}$ & $2-3$ & 115 & $58 \cdot 3$ & 37.8 & 13.9 & $1 \cdot 0$ & 14.5 & NA & NA & $15 \cdot 1$ & 98.0 & Bosscher et al. ${ }^{(184)}$ & 2002 \\
\hline $\begin{array}{l}\text { France } \\
\text { Germany }\end{array}$ & $\begin{array}{l}2006-2007 \\
1992-2007\end{array}$ & $\begin{array}{l}\text { INCA-2 } \\
\text { DONALD study, } \\
\text { Dortmund }\end{array}$ & $\begin{array}{l}3-17 \\
7\end{array}$ & $\begin{array}{l}1455 \\
380\end{array}$ & $\begin{array}{l}24 \cdot 2 \\
49 \cdot 4\end{array}$ & $\begin{array}{l}13.5 \\
\mathrm{NA}\end{array}$ & $\begin{array}{l}5 \cdot 3 \\
\mathrm{NA}\end{array}$ & $\begin{array}{l}4.4 \\
\text { NA }\end{array}$ & $\begin{array}{l}7.9 \\
\mathrm{NA}\end{array}$ & $\begin{array}{l}14.9 \\
18.5\end{array}$ & $\begin{array}{l}3.6 \\
\mathrm{NA}\end{array}$ & $\begin{array}{r}9.8 \\
20.4\end{array}$ & $\begin{array}{l}83 \cdot 6 \\
88.3\end{array}$ & $\begin{array}{l}\text { AFSSA }{ }^{(100)} \\
\text { Buyken et al. } \\
(180)\end{array}$ & $\begin{array}{l}2009 \\
2008\end{array}$ \\
\hline Italy & $2000-2001$ & $\begin{array}{l}\text { Schoolchildren } \\
\text { in Rome }\end{array}$ & Mean 17 & $125 \mathrm{M} 108 \mathrm{~F}$ & 49 & NA & NA & NA & 7 & 21 & 6 & 14 & 100 & Leclercq et al. ${ }^{(174)}$ & 2004 \\
\hline Spain & 1998-1999 & $\begin{array}{l}\text { Schoolchildren in } \\
\text { four towns }\end{array}$ & $6-7$ & 1112 & $16 \cdot 7$ & $11 \cdot 2$ & NA & NA & $7 \cdot 4$ & $10 \cdot 9$ & $16 \cdot 2$ & 25.6 & 76.8 & $\begin{array}{l}\text { Royo-Bordonada } \\
\text { et al. }{ }^{(189)}\end{array}$ & 2003 \\
\hline Sweden & 2003 & National Survey & $\begin{array}{l}4 \text { years, } \\
\text { Gr 2, } \\
\text { Gr } 5\end{array}$ & 1016 & $\begin{array}{l}4 \text { years: } 46 ; \\
\text { Gr 2: } 49 ; \\
\text { Gr 5: } 50\end{array}$ & $\begin{array}{l}4 \text { years: } 21 ; \\
\text { Gr 2: } 25 ; \\
\text { Gr 5: } 28\end{array}$ & $\begin{array}{l}4 \text { years: } 4 ; \\
\text { Gr 2: } 5 ; \mathrm{Gr} \\
54\end{array}$ & $\begin{array}{l}4 \text { years: } 10 ; \\
\text { Gr 2: 6; Gr } \\
5: 6\end{array}$ & $\begin{array}{l}4 \text { years: } 9 \\
\text { Gr 2: } 11 \\
\text { Gr 5: } 13\end{array}$ & $\begin{array}{l}4 \text { years: } 7 \\
\text { Gr 2: } 8 ; \mathrm{Gr} \\
\text { 5: } 6\end{array}$ & $\begin{array}{l}4 \text { years: } 1 \text {; } \\
\text { Gr 2: } 1 ; \mathrm{Gr} \\
5: 1\end{array}$ & $\begin{array}{l}4 \text { years: } 21 \\
\text { Gr 2: } 14 \\
\text { Gr 5: } 10\end{array}$ & $\begin{array}{l}4 \text { years: } 94 ; \\
\text { Gr 2: } 96 ; \\
\text { Gr 5: } 93\end{array}$ & $\begin{array}{l}\text { Enghardt Barbieri } \\
\text { et al. }{ }^{(182)}\end{array}$ & 2006 \\
\hline UK & 2009-2011 & $\begin{array}{l}\text { National Diet and } \\
\text { Nutrition Survey }\end{array}$ & $1.5-18$ & 1582 & $\begin{array}{c}1.5-3 \text { years: } \\
40 ; 4-10 \\
\text { years: } 43 \\
11-18 \\
\text { years: } 41\end{array}$ & $\begin{array}{c}1.5-3 \text { years: } \\
15 ; 4-10 \\
\text { years: } 19 ; \\
11-18 \\
\text { years: } 19\end{array}$ & $\begin{array}{l}1.5-3 \text { years: } \\
8 ; 4-10 \\
\text { years: } 9 \\
11-18 \\
\text { years: } 11\end{array}$ & $\begin{array}{c}1.5-3 \text { years: } \\
10 ; 4-10 \\
\text { years: } 10 \\
11-18 \\
\text { years: } 6\end{array}$ & $\begin{array}{l}1.5-3 \text { years: } \\
9 ; 4-10 \\
\text { years: } 11 \\
11-18 \\
\text { years: } 14\end{array}$ & $\begin{array}{c}1.5-3 \text { years: } \\
16 ; 4-10 \\
\text { years: } 16 ; \\
11-18 \\
\text { years: } 15\end{array}$ & NA & $\begin{array}{l}1.5-3 \text { years: } \\
17 ; 4-10 \\
\text { years: } 12 \\
11-18 \\
\text { years: } 7\end{array}$ & $\begin{array}{c}1.5-3 \text { years: } \\
\text { 95; } 4-10 \\
\text { years: } 99 \\
11-18 \\
\text { years: } 98\end{array}$ & $\begin{array}{l}\text { Public Health } \\
\text { England \& Food } \\
\text { Standards } \\
\text { Agency }^{(165)}\end{array}$ & 2012 \\
\hline USA & 2003-2006 & NHANES & $2-18$ & 7332 & $43 \cdot 8$ & $10 \cdot 3$ & $4 \cdot 1$ & $6 \cdot 3$ & 6.9 & $\begin{array}{r}6 \cdot 6 \\
-6\end{array}$ & 5.5 & $10 \cdot 4$ & $76 \cdot 0$ & Keast et al. ${ }^{(190)}$ & 2010 \\
\hline USA & 2009-2010 & NHANES & $2-18$ & 3124 & 33.4 & $12 \cdot 8$ & $1 \cdot 2$ & 7.7 & NA & 13.7 & $10 \cdot 1$ & 14.9 & 89.9 & Reicks et al. ${ }^{(188)}$ & 2014 \\
\hline
\end{tabular}

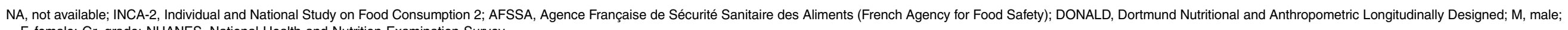
$F$, female; Gr, grade; NHANES, National Health and Nutrition Examination Survey. 
Table 18. Intakes of resistant starch

\begin{tabular}{|c|c|c|c|c|c|c|c|c|c|}
\hline $\begin{array}{l}\text { Year of } \\
\text { assessment }\end{array}$ & Country & Group studied & $\begin{array}{l}\text { Age } \\
\text { (years) }\end{array}$ & Sex & $n$ & $\begin{array}{l}\text { Dietary assessment } \\
\text { method }\end{array}$ & $\begin{array}{l}\text { Resistant starch } \\
\text { intake }(\mathrm{g} / \mathrm{d})\end{array}$ & Reference & Year \\
\hline 1999-2002 & USA & NHANES & $2+$ & $\mathrm{M}$ and $\mathrm{F}$ & 17599 & $24 \mathrm{~h}$ recall & 4.9 & Murphy et al. ${ }^{(191)}$ & 2008 \\
\hline 1993 & Australia & National Survey & $18+$ & $\mathrm{M}$ and $\mathrm{F}$ & & $24 \mathrm{~h}$ recall & M 5.3, F $5 \cdot 0$ & Baghurst et al. ${ }^{(192)}$ & 1996 \\
\hline 1991 & Italy & $\begin{array}{l}\text { Food consumption } \\
\text { survey in Italy }\end{array}$ & & $\mathrm{M}$ and $\mathrm{F}$ & & Household & 8.5 & Brighenti et al. ${ }^{(193)}$ & 1998 \\
\hline NA & China & & & $\mathrm{M}$ and $\mathrm{F}$ & 6382 & $7 \mathrm{~d}$ record & 14.9 & Chen et al. ${ }^{(194)}$ & 2010 \\
\hline
\end{tabular}

NHANES, National Health and Nutrition Examination Survey; M, male; F, female; NA, not available.

has the disadvantage that depending on the populations included, the amounts of dietary fibre consumed in these comparator groups may vary greatly between studies.

\section{All-cause mortality}

In terms of all-cause mortality risk, a recent meta-analysis using seven prospective cohort studies observed an $11 \%$ reduction in mortality risk for each $10 \mathrm{~g} / \mathrm{d}$ increment of dietary fibre consumed $(95 \% \text { CI } 0.85,0.92)^{(39)}$. When comparing the highest (mean approximately $27 \mathrm{~g} / \mathrm{d}$ ) and lowest (mean approximately $15 \mathrm{~g} / \mathrm{d}$ ) fibre intake groups, the pooled estimate indicated a $23 \%$ lower risk in the highest consumers after adjustment for major recognised confounding variables.

$\mathrm{Kim} \& \mathrm{Je}^{(39)}$ located fewer studies providing risk estimates for all-cause mortality in relation to the source of dietary fibre. However, they were able to pool the cohort-derived risk estimates for cereal fibre, vegetable fibre and fruit fibre based on the results from three, two and two studies, respectively ${ }^{(39)}$. Overall, the strongest inverse associations were observed with increasing cereal fibre consumption ( $8 \%$ reduction in risk per $10 \mathrm{~g} / \mathrm{d}$ ), with weaker associations being observed for vegetable and fruit sources. These results should, however, be treated with caution for a number of reasons. First, the number of studies included in the meta-analyses of fibre sources was very small. Furthermore, fatality as an outcome is limited with regard to informing about the role of diet in disease prevention since it includes both disease incidence and subsequent survival. It is possible that high-fibre diets may have an impact differently on incidence and survival, since their underlying pathologies may differ. Indeed, associations do appear to be different considering fatal and non-fatal CVD outcomes in relation to dietary fibre intake ${ }^{(40,41)}$. Mortality is not an ideal outcome therefore to judge whether a dietary exposure may make an impact on disease prevention per se. Nonetheless, the meta-analyses of Kim \& $\mathrm{Je}^{(39)}$ are useful in terms of hypothesis generation and for comparison with summary estimates of risk of specific disease incidence in relation to dietary fibre consumption.

\section{Cardiometabolic health}

CVD. With a strong relationship with unhealthy lifestyles, including tobacco smoking, low levels of physical activity and poor diets, the WHO has estimated that over three-quarters of CVD deaths may be preventable by appropriate lifestyle change ${ }^{(42)}$. One such change may be adherence to a dietary pattern encompassing a range of high-fibre foods which may make an impact on reducing CVD risk through reduction in recognised CVD risk factors such as raised blood cholesterol, hypertension, systemic inflammation, impaired glucose tolerance and elevated body fat ${ }^{(43)}$. A recently published systematic review and meta-analysis of seventeen cohort studies that provided risk estimates for incident fatal events of CVD in relation to intakes of total fibre and fibre sources confirmed the association between low dietary fibre consumption and increased risk of $\mathrm{CVD}^{(44)}$. Random-effects dose-response metaanalyses were conducted by pooling provided or derived doseresponse trends for each included cohort. The pooled estimate of risk was then expressed for each increment of dietary fibre based on one standard deviation of mean intakes in European populations which, for TDF, was for each $7 \mathrm{~g} / \mathrm{d}$ consumed. This approach was undertaken for CVD events, and separately for CHD events, and in a further publication for cerebrovascular (stroke) events ${ }^{(44,45)}$. The pooled estimates of risk are included in Table 19, and for TDF intake indicate a reduction in risk of these CVD events between 7 and $9 \%$ for each $7 \mathrm{~g} / \mathrm{d}$ increment consumed.

The relationship between fibre sources and risk of CVD events was similar for total CVD outcomes, coronary, and cerebrovascular events, notwithstanding the limited number of studies available for certain analyses. Overall, intakes of cereal and vegetable fibre sources, and insoluble dietary fibre were more strongly associated with lower risk of CVD, CHD and stroke than fruit fibre and soluble dietary fibre (see Table 19).

\section{CVD risk factors}

Hypertension/blood pressure. Two reviews of randomised controlled trials of fibre and blood pressure were published in 2005 by Streppel et al. ${ }^{(46)}$ and Whelton et al. ${ }^{(47)}$. Both described a significant inverse relationship between fibre consumption and blood pressure, with reductions in blood pressure by 1-2 mmHg with fibre supplementation. Greater reductions were observed in older, more hypertensive populations. Whelton et $a l^{(47)}$ also described some evidence of a greater magnitude of reduction with fruit and vegetable sources of dietary fibre rather than grain sources, although this finding was based on a very limited number of studies (four and nine trials, respectively). More recently, randomised controlled trials with blood pressure outcomes that were of at least of 6 weeks' duration were identified by Evans et al. ${ }^{(48)}$, and pooled in random-effects meta-analyses. No overall reduction in blood pressure was found when the results of all eighteen trials were pooled, comparing high- and low-fibre intervention groups regardless of dietary fibre type. However, diets rich in $\beta$-glucans were 
found to reduce systolic blood pressure by $2.9 \mathrm{mmHg}$ and diastolic blood pressure by $1.5 \mathrm{mmHg}$ for a median difference in $\beta$-glucans of $4 \mathrm{~g} / \mathrm{d}$.

Hyperlipidaemias. In 1999, Brown et al. ${ }^{(49)}$ undertook a metaanalysis of sixty-seven trials that demonstrated a reduction of total cholesterol by $0.047 \mathrm{mmol} / \mathrm{l}$, and LDL-cholesterol by $0.057 \mathrm{mmol} / \mathrm{l}$ with daily consumption of fibre isolates or fibreenriched products containing $2-10 \mathrm{~g}$ of soluble fibre provided by pectin, guar gum, psyllium and oat bran. Similar findings, albeit using narrower trials inclusion criteria, were reported in the evidence reviews prepared for the SACN Carbohydrate Working Group ${ }^{(34)}$. Total and LDL-cholesterol were lowered by supplementation with mixed, soluble types of dietary fibre, and total and LDL-cholesterol and fasting TAG levels were significantly lowered by supplementation with oats, oat bran or $\beta$-glucan-supplemented diets. Other types of dietary fibre supplementation did not consistently reduce blood lipids in these trials of normolipidaemic individuals. Some of this evidence forms the basis for the authorised health claims that certain fibre types, including $\beta$-glucans from oats and barley, pectin, guar gum and chitosan, may contribute to the maintenance of normal blood cholesterol concentrations (see Table 20).

Type 2 diabetes. Some of the earliest studies of the effects of dietary fibre on health were concerned with its modulation of blood glucose and insulin, and as listed in Table 20, there is sufficient evidence to support a number of authorised health claims that certain types of dietary fibre, including arabinoxylan, $\beta$-glucans from oats and barley, and pectins if consumed within a meal, may contribute to the reduction of the blood glucose rise after that meal. Furthermore, two systematic reviews of prospective cohort studies, with dose-response meta-analyses, of the association between dietary fibre and risk of type 2 diabetes mellitus have been published recently that indicate a reduction in long-term risk ${ }^{(50,51)}$. Both used similar methodologies, though with eleven and seventeen prospective cohort studies, respectively, and equally concluded that there is clear evidence of diminishing risk of type 2 diabetes mellitus with increasing consumption of TDF (approximately $6 \%$ reduction in risk with each additional $7 \mathrm{~g}$ daily consumption; see Table 19). Similarly, both reviews reported that fibre from cereals was associated with reduced diabetes risk. With each $7 \mathrm{~g} / \mathrm{d}$ consumed, Threapleton et al. ${ }^{(50)}$ reported that risk was reduced by $21 \%$, although there was evidence of considerable heterogeneity between studies. Both insoluble and soluble fibres were separately associated with lower risk but no associations were observed when studies reporting fibre from fruits or from vegetables were separately examined.

Obesity (energy intake and appetite). Early studies conducted by Haber et al. ${ }^{(52)}$, in which eating rate and satiety were assessed following consumption of equi-energetic loads of whole apples, apple purée and juiced apples, highlighted the importance of cell structure integrity, energy density and dietary fibre meal content on appetite control. In this study, these factors were inter-linked, but later studies have attempted to 
Table 20. Authorised health claims related to dietary fibre in the USA and in the European Union (EU) ${ }^{(195)}$

Remarks

Country Subject of the claim Claim Conditions of

The claim is limited to foods that are or contain grain

Fibre-containing grain products, fruits and vegetables and risk of

Model claim: low-fat diets rich in fibre-containing grain products, fruits, and vegetables may reduce the with many factors

USA Fruits, vegetables and grain products that contain fibre, particularly soluble fibre, and risk of $\mathrm{CHD}$ foods and risk of $\mathrm{CHD}$

Model claim: diets low in saturated fat and cholesterol and rich in fruits, vegetables, and grain products that contain some types of dietary fibre, particularly a disease associated with many factors foluble fibre source], as part of a diet low in of heart disease. A serving of [name of food] supplies grams of [the soluble fibre] necessary per $d$ to have this effect

Article 13(1)

Arabinoxylan produced
from wheat endospe from wheat endospe postprandial glycaemic responses

EU Barley grain fibre and increase in faecal bulk

EU $\quad \beta$-Glucans and main nance of normal concentrations

EU $\quad \beta$-Glucans from oats and barley and reduction of postprandial glycaemic responses

EU Glucomannan (konjac mannan) and maintenance of norma blood cholesterol concentrations

EU Glucomannan (konjac mannan) and reducti of body weight

Glucomannan in the context of
diet contributes to weight loss

Consumption of arabinoxylan as part of a mea contributes to a reduction of the blood glucose rise after that meal

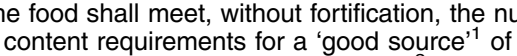
content requirements for a 'good source'1 0 of
dietary fibre, and shall be a "low-fat'" food

The food shall meet the requirement for a 'low aturated fat' ${ }^{3}$, 'low cholesterol' ${ }^{4}$, and 'low-fat' food. The food shall contain, without fortification,

The food shall be a 'low saturated fat' ${ }^{3}$ and 'low cholesterol" food. The food shall also be a "lowfue to fat derived from whole exceeds the fat conten due to fat derved from whole oats. Whole oats or fibre per RACC. Oatrim or barley $\beta$ fibre shall contain at least $0.75 \mathrm{~g}$ of $\beta$-glucan fibre per RACC. Psyllium husk and psyllium food shall contain at least $1.7 \mathrm{~g}$ of soluble fibre per RACC

The claim may be used only for food which contains at least $8 \mathrm{~g}$ of arabinoxylan-rich fibre produced

from wheat endosperm (at least $60 \%$ arabinoxylan quantified portion as part of the meal

Barley grain fibre contributes to an increase in faecal The claim may be used only for food which is high in listed in the Annex to Regulation (EC) No 1924/2006

$\beta$-Glucans contribute to the maintenance of normal The claim may be used only for food which contains at least $1 \mathrm{~g}$ of $\beta$-glucans from oats, oat bran, barley, barley bran, or from mixtures of these sources per quantified portion

Consumption of $\beta$-glucans from oats or barley as part The claim may be used only for food which contain of a meal contributes to the reduction of the blood glucose rise after that meal

at least $4 \mathrm{~g}$ of $\beta$-glucans from oats or barley for each $30 \mathrm{~g}$ of available carbohydrates in a quantified portion as part of the meal

contributes to the maintenance of

The claim may be used only for food daily intake of $4 \mathrm{~g}$ of glucomannan

The claim may be used only for food which contain $1 \mathrm{~g}$ of glucomannan per quantified portion

Oat grain fibre and

Oat grain fibre contributes to an increase in faecal increase in faecal butk bulk

The claim may be used only for food which is high in that fibre as referred to in the claim HIGH FIBRE as

Pectins and reduction of Consumption of pectins with a meal contributes to the The claim may be used only for food which contains postprandial glycaemic reduction of the blood glucose rise after that meal $10 \mathrm{~g}$ of pectins per quantified portion responses products, fruit, and vegetables that contain dietary

The claim does not specify types of dietary fibre that may be related to isk of cancer

The claim is limited to those fruits, vegetables, and grains that contain fibre.

The term 'fibre', 'dietary fibre', 'some (types of) dietary fibre', 'some (dietary) fibres', or 'soluble fibre may be used

red on foods containing oat bran barley and why oat flour, Oatrim, whole grain psyllium husk.

The claim may specify the name of the eligible soluble fibre

Information shall be given to the consumer that the beneficial effect is obtained by consuming the arabinoxylan-rich fibre produced from wheat

endosperm as part of the meal

nformation shall be given to the consumer that the beneficial effect is obtained with a daily intake of $3 \mathrm{~g}$ of $\beta$-glucans from oats, oat bran, barley, barley bran, or from mixtures of these $\beta$-glucans

information shall be given to the consumer that the beneficial effect is obtained by consuming the $\beta$ glucans from oats or barley as part of the meal

Information shall be given to the consumer that the beneficial effect is obtained with a daily intake of $4 \mathrm{~g}$ of glucomannan. Warning of choking to be given for individuals with swallowing difficulties or when ingesting with inadequate fluid intake advice on taking with plenty of water to ensure substance reaches stomach

Information shall be given to the consumer that the beneficial effect is obtained with a daily intake of $3 \mathrm{~g}$ of glucomannan in three doses of $1 \mathrm{~g}$ each, together with 1-2 glasses of water, before meals and in the context of an energy-restricted diet

Information shall be given to the consumer that the beneficial effect is obtained by consuming $10 \mathrm{~g}$ of pectins as part of the meal. Warning of choking to be given for individuals with swallowing difficulties or when ingesting with inadequate fluid intake advice on taking with plenty of water to ensure substance reaches stomach 


\begin{tabular}{|c|c|c|c|c|}
\hline Country & Subject of the claim & Claim & Conditions of use & Remarks \\
\hline EU & $\begin{array}{l}\text { Pectins and maintenance } \\
\text { of normal blood } \\
\text { cholesterol } \\
\text { concentrations }\end{array}$ & $\begin{array}{l}\text { Pectins contribute to the maintenance of normal } \\
\text { blood cholesterol levels }\end{array}$ & $\begin{array}{l}\text { The claim may be used only for food which provides a } \\
\text { daily intake of } 6 \mathrm{~g} \text { of pectins }\end{array}$ & $\begin{array}{l}\text { Information shall be given to the consumer that the } \\
\text { beneficial effect is obtained with a daily intake of } \\
6 \mathrm{~g} \text { of pectins. Warning of choking to be given for } \\
\text { individuals with swallowing difficulties or when } \\
\text { ingesting with inadequate fluid intake - advice on } \\
\text { taking with plenty of water to ensure substance } \\
\text { reaches stomach }\end{array}$ \\
\hline EU & $\begin{array}{l}\text { Resistant starch and } \\
\text { reduction of } \\
\text { postprandial glycaemic } \\
\text { responses }\end{array}$ & $\begin{array}{l}\text { Replacing digestible starches with resistant starch in } \\
\text { a meal contributes to a reduction in the blood } \\
\text { glucose rise after that meal }\end{array}$ & $\begin{array}{l}\text { The claim may be used only for food in which } \\
\text { digestible starch has been replaced by resistant } \\
\text { starch so that the final content of resistant starch is } \\
\text { at least } 14 \% \text { of total starch }\end{array}$ & \\
\hline EU & $\begin{array}{l}\text { Rye fibre and changes in } \\
\text { bowel function }\end{array}$ & Rye fibre contributes to normal bowel function & $\begin{array}{l}\text { The claim may be used only for food which is high in } \\
\text { that fibre }{ }^{6} \text { as referred to in the claim HIGH FIBRE } \\
\text { as listed in the Annex to Regulation (EC) No 1924/ } \\
2006\end{array}$ & \\
\hline EU & $\begin{array}{l}\text { Wheat bran fibre and } \\
\text { reduction in intestinal } \\
\text { transit time }\end{array}$ & $\begin{array}{l}\text { Wheat bran fibre contributes to an acceleration of } \\
\text { intestinal transit }\end{array}$ & $\begin{array}{l}\text { The claim may be used only for food which is high in } \\
\text { that fibre }{ }^{6} \text { as referred to in the claim HIGH FIBRE } \\
\text { as listed in the Annex to Regulation (EC) No 1924/ } \\
2006\end{array}$ & $\begin{array}{l}\text { Information shall be given to the consumer that the } \\
\text { claimed effect is obtained with a daily intake of at } \\
\text { least } 10 \mathrm{~g} \text { of wheat bran fibre }\end{array}$ \\
\hline EU & $\begin{array}{l}\text { Wheat bran fibre and } \\
\text { increase in faecal bulk }\end{array}$ & $\begin{array}{l}\text { Wheat bran fibre contributes to an increase in faecal } \\
\text { bulk }\end{array}$ & $\begin{array}{l}\text { The claim may be used only for food which is high in } \\
\text { that fibre }{ }^{6} \text { as referred to in the claim HIGH FIBRE } \\
\text { as listed in the Annex to Regulation (EC) No 1924/ } \\
2006\end{array}$ & \\
\hline EU & $\begin{array}{l}\text { Chitosan and } \\
\text { maintenance of normal } \\
\text { blood LDL-cholesterol } \\
\text { concentrations }\end{array}$ & $\begin{array}{l}\text { Chitosan contributes to the maintenance of normal } \\
\text { blood cholesterol levels }\end{array}$ & $\begin{array}{l}\text { The claim may be used only for food which provides a } \\
\text { daily intake of } 3 \mathrm{~g} \text { of chitosan }\end{array}$ & $\begin{array}{l}\text { Information shall be given to the consumer that the } \\
\text { beneficial effect is obtained with a daily intake of } \\
3 \mathrm{~g} \text { of chitosan }\end{array}$ \\
\hline EU & $\begin{array}{l}\text { Guar gum and } \\
\text { maintenance of normal } \\
\text { blood cholesterol } \\
\text { concentrations }\end{array}$ & $\begin{array}{l}\text { Guar gum contributes to the maintenance of normal } \\
\text { blood cholesterol levels }\end{array}$ & $\begin{array}{l}\text { The claim may be used only for food which provides a } \\
\text { daily intake of } 10 \mathrm{~g} \text { of guar gum }\end{array}$ & $\begin{array}{l}\text { Information shall be given to the consumer that the } \\
\text { beneficial effect is obtained with a daily intake of } \\
10 \mathrm{~g} \text { of guar gum. Warning of choking to be given } \\
\text { for individuals with swallowing difficulties or when } \\
\text { ingesting with inadequate fluid intake - advice on } \\
\text { taking with plenty of water to ensure substance } \\
\text { reaches stomach }\end{array}$ \\
\hline \multicolumn{5}{|c|}{ Article $14(1)(a)$} \\
\hline & $\begin{array}{l}\text { Oat } \beta \text {-glucan and risk of } \\
\text { heart disease }\end{array}$ & $\begin{array}{l}\text { Oat } \beta \text {-glucan has been shown to lower/reduce blood } \\
\text { cholesterol. High cholesterol is a risk factor in the } \\
\text { development of CHD }\end{array}$ & $\begin{array}{l}\text { The claim can be used for foods which provide at } \\
\text { least } 1 \mathrm{~g} \text { of oat } \beta \text {-glucan per quantified portion }\end{array}$ & $\begin{array}{l}\text { Information shall be given to the consumer that the } \\
\text { beneficial effect is obtained with a daily intake of } \\
3 \mathrm{~g} \text { of oat } \beta \text {-glucan }\end{array}$ \\
\hline
\end{tabular}

RACC, reference amounts customarily consumed.

Provides $10-19 \%$ of the Dietary Reference Value per RACC.

$21 \mathrm{~g}$ or less per RACC and per $50 \mathrm{~g}$ if RACC is small; meals and main dishes: $3 \mathrm{~g}$ or less per $100 \mathrm{~g}$ and not more than $30 \%$ of energy from fat.

$1 \mathrm{~g}$ or less per RACC and $15 \%$ or less of energy from saturated fat; meals and main dishes: $1 \mathrm{~g}$ or less per $100 \mathrm{~g}$ and less than $10 \%$ of energy from saturated fat.

${ }^{4} 20 \mathrm{mg}$ or less per RACC and per $50 \mathrm{~g}$ of food if RACC is small; meals and main dishes: $20 \mathrm{mg}$ or less per $100 \mathrm{~g}$

${ }^{6}$ Provides at least $6 \mathrm{~g}$ of fibre per $100 \mathrm{~g}$ or at least $3 \mathrm{~g}$ of fibre per $100 \mathrm{kcal}(418 \mathrm{~kJ})$. 
determine the influence of dose, source, fibre type and mode of delivery of dietary fibre (whole foods, foods enriched with dietary fibre and fibre isolated from the cell matrix) on appetite control and body weight management. Despite some evidence of biologically plausible mechanisms for a reduction in appetite with consumption of certain types of dietary fibre, one recent systematic review exploring the effects of fibre on energy intake and subjective appetite ratings has concluded that collectively, acute studies comparing dietary fibre interventions with a lower- or no-fibre control show limited effects of fibre ${ }^{53)}$. However, in the region of $22-39 \%$ of interventions found evidence of either reduced energy or food intake or motivational ratings. These studies utilised $\beta$-glucan, lupin kernel fibre, rye bran, whole grain rye, or a mixed high-fibre diet.

Wanders et al. ${ }^{(54)}$ also conducted a thorough systematic review of dietary fibre intervention studies assessing appetite, acute and long-term energy intake or body weight, with interventions grouped according to chemical structure and physicochemical properties (viscosity, solubility and fermentability). Overall, they reported that the effects of fibre interventions were relatively small (average reduction in energy intake and body weight was $0.15 \mathrm{MJ} / \mathrm{d}$, and $0.4 \%$ per 4 weeks, respectively) and there was little evidence of any dose-response relationships. They observed a disparity in the relative effects of different types of dietary fibre on short- and long-term outcomes (energy intake and body weight). In the longer-term studies, arabinoxylan-rich fibres (mainly from grains), fructans and RS were most strongly linked to reduced energy intake, although in acute studies the most potent types were pectins and most glucans. In terms of impact on body-weight reduction, yet further different types of dietary fibre were most potent (chitosan, dextrin and marine polysaccharides). However, more viscous types of fibre (such as guar gum, $\beta$-glucan and pectin) were associated with reduced appetite more often than nonviscous fibres.

Very few intervention studies have been conducted employing a whole-diet approach, most having a functional food approach, with exploration of dietary fibre types through the use of fibre isolates delivered as supplements or incorporated into specific food vehicles. Given the wide variability in physicochemical properties of such isolates, the variation in dose employed and extent of mixing of the fibre to energy sources in the rest of the diet, it is therefore not surprising that the majority of studies have failed to demonstrate a marked impact on energy intake and/or body weight. It is difficult to translate the action of specific fibre isolates into guidance around which sources of fibre may be most effective for appetite management or weight control.

Observational evidence for the effects of different sources or types of dietary fibre on body weight management is rather limited and inconsistent in terms of strength of association. In participants of the Finnish Diabetes Prevention Study ${ }^{(55)}$, mean weight losses and waist reduction over 3 years of follow-up were greater with increasing intakes of dietary fibre in a clear step-wise manner. However, the impact of different sources of dietary fibre was not described. There is some evidence from pooled data from five EPIC centres that individuals with higher total and grain fibre intakes experienced smaller annual weight gains $^{(56)}$. Over the 6.5-year follow-up, for each $10 \mathrm{~g}$ greater intake of total fibre, weight gain was less by $39 \mathrm{~g} /$ year in the 89 $000+$ European participants. This apparently small annual improvement may potentially contribute to significantly greater lifetime weight stability in higher fibre consumers. For grain sources of dietary fibre, the association was somewhat stronger at $-77 \mathrm{~g} /$ year for each additional $\mathrm{g}$ consumed. This body weight-related association was not observed for fruit or vegetable sources of dietary fibre, but total and all sources of fibre were associated with lower annual waist circumference gains.

\section{Gastrointestinal health}

Constipation and faecal weight. Constipation is one of the most common gastrointestinal complaints in Europe, with estimates of prevalence ranging from 5 to $35 \%$ of the general population depending on the definition criteria used ${ }^{(57)}$. Definitions generally encompass aspects of defecation frequency with or without measures of stool consistency ${ }^{(57)}$. Although the causes of constipation are variable, including consequences of diseases, medication effects, increasing age and lifestyle aspects including dietary habits and physical activity, dietary fibre plays a clear role in maintaining gastrointestinal health through increasing faecal weight.

In 2007, Elia \& Cummings ${ }^{(58)}$ summarised the results of 150 separate studies published between 1932 and 1992 on the effects of various types and sources of dietary fibre on faecal weight in humans. The summary results, expressed as the weighted mean increase in stool weight per g of fibre fed, indicate the greatest increase in faecal weight with raw wheat bran, which for each $1 \mathrm{~g}$ consumed, increases wet stool weight by $7 \cdot 2 \mathrm{~g}$. Cooked wheat bran is somewhat less effective $(4.4 \mathrm{~g} / \mathrm{g}$ ), as were other cereal sources (oats $3.4 \mathrm{~g} / \mathrm{g}$ and maize $2.9 \mathrm{~g} / \mathrm{g})^{(59)}$. Fruit and vegetable sources were also very effective at increasing faecal weight $(6 \mathrm{~g} / \mathrm{g})$, but soya and other legume fibre and pectin feeding generated the smallest increases ( 1.5 and $1.3 \mathrm{~g} / \mathrm{g}$, respectively) ${ }^{(59)}$. Some of this evidence forms the basis for the authorised health claims listed in Table 9 for increasing faecal bulk.

Despite long-standing evidence of an impact of dietary fibre on faecal weight, reports of an association between dietary fibre and risk of constipation are sparse and inconsistent ${ }^{(59,60)}$. Yang et $a l^{(61)}$ undertook a meta-analysis of five good-quality randomised controlled trials that compared the effects of dietary fibre interventions with placebo in patients with constipation. Three of the included randomised controlled trials used glucomannan, one wheat bran, and one cocoa husk. One of the five studies was on adults, the others on children. The studies were therefore rather heterogeneous in nature. Despite this, results indicated an increased bowel movement frequency per week in the fibretreated group compared with the placebo group (OR 1.19; $P<0.05)$, with no significant heterogeneity among the studies. The authors concluded that dietary fibre intake can increase stool frequency in patients with constipation. The evidence for an impact of dietary fibre on stool consistency, treatment success, laxative use and painful defecation is limited, and inconsistent.

A small number of observational studies have explored the relationship between dietary fibre and bowel frequency or risk of 
constipation. A cross-sectional study ${ }^{(62)}$ of more than 20000 men and women from EPIC-Oxford reported that NSP intake was significantly associated with having seven or more bowel movements per week, the OR being 1.43 for women who consumed $>20.9 \mathrm{~g} / \mathrm{d}$ compared with those who consumed $<11.3 \mathrm{~g} / \mathrm{d}$. However, there was no further analysis of the sources of dietary fibre ${ }^{(62)}$. Using detailed dietary data from more than 10000 middle-aged women in the UK Women's Cohort Study, and follow-up information on stool frequency and consistency, Alrefaai et al. ${ }^{(63)}$ observed a 40-50\% reduction in the odds of constipation in women in the highest NSP intake quintile compared with the lowest. Further exploration of the association between constipation and sources of dietary fibre in this prospective follow-up analysis found that constipation odds were significantly lower with increasing consumption of all sources of dietary fibre (cereal, fruit, vegetable and legume), using a constipation definition based on faecal frequency. When employing a definition based on both frequency and consistency, however, the odds for constipation were statistically lower only for vegetable sources of fibre (OR $0.42 ; P<0 \cdot 01$ ) when comparing the highest consumers with the lowest.

Diverticular disease. Diverticular disease occurs when small pouches (diverticula) develop in the wall of the large bowel at points of weakness, caused by excessive intra-luminal pressure. These diverticula may become inflamed, may bleed and, in complicated cases, form abscesses, fistula, cause bowel obstruction, peritonitis and septicaemia. Diverticular disease was one of the first conditions that Painter \& Burkitt ${ }^{(64)}$ highlighted in the 1970s as being potentially linked to low dietary fibre consumption. A relatively small number of cohort studies have subsequently explored the relationship between dietary fibre intakes and risk of diverticular disease; these have consistently found evidence of a lower incidence with higher total fibre consumption ${ }^{(65-67)}$. In the most recent analysis conducted using participants of the UK-based Million Women study, Crowe et al ${ }^{(67)}$ reported a $25 \%$ lower risk of diverticular disease in women consuming $18.6 \mathrm{~g} / \mathrm{d}$ compared with the women in the lowest consumption quintile $(9.5 \mathrm{~g} / \mathrm{d}$ or less). In this and other cohort studies, there have also been indications of difference in risk according to source of dietary fibre. After adjustment for other sources of dietary fibre, Crowe et al. found the greatest reductions in risk with dietary fibre derived from cereal and fruit sources (per $5 \mathrm{~g} / \mathrm{d}$ increment, relative risk (RR) $0 \cdot 84$, and $0 \cdot 81$, respectively), but no association with nonpotato, vegetable fibre (RR 1.03) and an increased risk with potato fibre $(\text { RR } 1.04)^{(67)}$

Oesophageal cancer. Dietary fibre has been suggested as a potentially protective dietary component with regard to cancer of the oesophagus due to its likely role in the prevention of obesity and amelioration of symptoms of gastro-oesophageal reflux. Coleman et al. ${ }^{(68)}$ undertook a systematic review and meta-analysis of the relationship between dietary fibre and the risk of precancerous lesions and cancer of the oesophagus. Using eight case-control studies, the pooled estimate of risk indicated a significant inverse association with the highest TDF intakes (OR 0.66). Just two studies explored fibre from specific food groups and the risk of oesophageal adenocarcinoma. Whilst vegetable and cereal fibre sources tended to be inversely associated with risk, no consistent associations were observed with fruit fibre sources. However, overall, too few studies provided data on the food groups contributing to dietary fibre intakes to permit conclusions to be drawn.

Gastric cancer. Zhang et al. ${ }^{(69)}$ recently explored whether TDF, or source and type of fibre is associated with risk of gastric cancer by pooling the risk estimates from two prospective cohort and twenty-four case-control studies ${ }^{(69)}$. With each study design, there was an inverse association with dietary fibre intake, though the size of effect was greater for the case-control studies (OR 0.53) than cohort (RR 0.89) when comparing the highest with the lowest intake categories. In the comparisons by source of dietary fibre, the pooled OR of four to six studies were all inverse and statistically significant (for cereal fibre, 0.58; for fruit fibre, 0.67; for vegetable fibre, 0.72). The OR for insoluble and soluble types of fibre were similar (0.42 and 0.41 , respectively).

Colorectal adenomas and colorectal cancer. The WCRF report $^{(70)}$ on updated evidence for colorectal cancer was published in 2011, and the resultant meta-analysis for the relationship between incident colorectal cancer risk and TDF intake included fifteen prospective cohort studies. For each $10 \mathrm{~g} / \mathrm{d}$ of TDF consumed, the risk of colorectal cancer was decreased by $10 \%$. This led to the conclusion that the evidence is convincing that high-fibre-containing foods decrease the risk of colorectal cancer. Sources of fibre in relation to risk of colorectal cancer risk were also explored in ten cohort studies, and whilst the summary risk estimates for all sources (cereal, fruit, vegetable) tended to be lower with increased consumption, only in the case of cereal fibre was this statistically significant (summary RR 0.90). For whole grains there was a $21 \%$ decreased risk per three servings per $\mathrm{d}$ for colorectal cancer and $16 \%$ decreased risk for colon cancer.

More recently, and since the publication of the meta-analysis by Aune et $a l .{ }^{(71)}$, the results from EPIC on the relationship between total and fibre sources and risk of colorectal cancer have been published ${ }^{(72)}$. After 11 years of follow-up, in which more than 4000 cases occurred, a $13 \%$ reduction in risk for each $10 \mathrm{~g} / \mathrm{d}$ increment consumed was observed. With regard to the source of dietary fibre, similar reductions in colon cancer risk were found for cereal, fruit and vegetable fibre. However, for rectal cancer the associations were statistically significant only for cereal sources of dietary fibre.

With regard to the relationship between dietary fibre consumption and development of colorectal cancer precursor lesions, Ben et al. ${ }^{(73)}$ undertook a random-effects meta-analysis of twenty case-control studies that reported the risk of colorectal adenoma incidence in relation to total fibre, fruit, vegetable and cereal sources of dietary fibre. The summary relative risks were broadly supportive of the findings for colorectal cancer risk, although the evidence base was more limited and was dominated by case-control, rather than prospective cohort, 
studies. The summary RR of colorectal adenoma were 0.84 for fruit fibre (six studies), 0.93 for vegetable fibre (six studies), and 0.76 for cereal fibre (nine studies) in analyses comparing the highest $v$. lowest intake groups. Thus, whilst there is apparent benefit in consuming a high-fibre diet generally with regard to reduction in risk of colorectal cancer and its precursors, cereal sources of dietary fibre seem to be particularly beneficial compared with fruit and vegetable sources.

\section{Neoplastic diseases other than gastrointestinal tract}

Breast cancer. According to the WCRF Second Expert Report ${ }^{(37)}$, the relationship between dietary variables and risk of postmenopausal breast cancer, other than the well-recognised positive association with adiposity and alcohol, is generally rather variable and weak. However, in a subsequent publication prepared by members of the WCRF continuous update project team, prospective cohort study results published up to August 2011 were pooled, permitting the synthesis of results from sixteen studies ${ }^{(74)}$. This revealed an inverse association between dietary fibre intake and breast cancer risk (in the dose-response analysis, a $5 \%$ reduction in risk for each $10 \mathrm{~g} / \mathrm{d}$ of dietary fibre consumed) and some apparent differential influence of the sources of dietary fibre on extent of risk reduction (see Table 19). The summary relative risks for all sources of dietary fibre were less than unity, but were not individually statistically significant. Soluble dietary fibre was associated with a lower summary risk estimate for each $10 \mathrm{~g} / \mathrm{d}$ consumed (RR 0.74).

Endometrial cancer. It has long been recognised that dietary habits are associated with risk of endometrial cancer, with strong evidence that obesity is a major risk factor ${ }^{(75)}$. Less research has been conducted on the role that dietary fibre consumption may play, despite the fact that it may modulate insulinaemia and insulin resistance and reduce the risk of type 2 diabetes, all of which are aetiologically implicated in endometrial cancer ${ }^{(76)}$. However, results from 288428 women in the EPIC cohort ${ }^{(77)}$, which identified 710 incident cases diagnosed during a mean 6.4 years of follow-up, suggested no association between TDF consumption and endometrial cancer risk. Data on sources of dietary fibre were not reported. In 2007, Bandera et $a l .{ }^{(78)}$ also undertook a synthesis of the epidemiological studies available at that time. Their dose-response metaanalysis of seven case-control studies contrasted with the results from EPIC, and the other prospective cohort study identified in that review ${ }^{(79)}$. The summary pooled estimate was indicative of a reduction in risk with increasing TDF consumption (RR 0.82, per $5 \mathrm{~g} / 1000 \mathrm{kcal}(4184 \mathrm{~kJ})$ ). Whilst some of these individual studies reported associations for specific sources or types of dietary fibre, overall the results were too few, and too inconsistent to permit any conclusions about whether associations vary by fibre source or type.

Prostate cancer. To date, there are few links between the incidence of prostate cancer and dietary variables, and limited exploration of the relationship between dietary fibre consumption and risk of the disease. The WCRF Second Expert
Report, published in $2007^{(37)}$, located just one cohort study and eighteen case-control studies, with no evidence of association in the majority of the studies, and inconsistencies in direction of association.

Pancreatic cancer. In the WCRF Second Expert Report, published in $2007^{(37)}$, only two case-control studies were identified that described the association between sources of dietary fibre and risk of pancreatic cancer. A meta-analysis was not conducted and the inconsistent results from these two studies that were conducted in the USA and Canada did not indicate a clear impact of dietary fibre source on risk ${ }^{(80,81)}$.

Ovarian cancer. The WCRF/American Institute for Cancer Research (AICR) Continuous Update Project systematic review of the Associations between Food, Nutrition and Physical Activity and the Risk of Ovarian Cancer, which was published in $2013^{(82)}$, provided a dose-response pooled estimate of the risk of incident ovarian cancer in relation to TDF intake. Three cohort studies, with 566 cases overall, were included in a random-effects metaanalysis, with no evidence of heterogeneity between the studies. The pooled estimate for each $5 \mathrm{~g} / \mathrm{d}$ increment of TDF was 0.94, indicating no association. However, the number of included studies was very small and the overall number of cases rather low. Accordingly, the WCRF panel judged that the evidence was limited and that no conclusion could be drawn on the strength of causality of the association ${ }^{(82)}$. No meta-analyses of dietary fibre source were reported here or elsewhere.

Renal cancer. Kidney cancer (which is mainly renal cell carcinoma) is among the 10th most common presenting cancers in the Western world, with suspected lifestyle and dietary aetiology ${ }^{(83,84)}$. Relatively few studies have addressed potential associations with dietary fibre consumption, but a recent review by Huang et al. ${ }^{(85)}$ synthesised the evidence from two cohort and five case-control studies in a meta-analysis. When comparing highest against lowest dietary fibre consumers, the pooled estimate of risk for renal cell carcinoma indicated a lowering of risk in the highest TDF consumers, with also some differential associations according to source of dietary fibre (greatest risk reductions for fibre from legume and vegetable sources, rather than grains or fruit). However, using a dose-response meta-analysis approach, the authors were unable to report any evidence of diminishing risk with increasing intakes of dietary fibre. This points to the need for further, large prospective cohort studies to explore potential links between dietary habits and kidney cancer.

\section{Summary of evidence linking total dietary fibre consumption and fibre sources to cardiometabolic disease and risk factors}

Multiple prospective cohort studies have provided evidence that individuals consuming diets rich in dietary fibre have a lower risk of CVD, including both CHD and cerebrovascular disease outcomes. Pooled risk estimates derived from meta-analyses indicate that for each additional $7 \mathrm{~g}$ dietary fibre consumed, the risk of CVD is reduced by about $7-9 \%$. With 
regard to the strength of association for major sources of dietary fibre, there is consistent evidence of a reduction in risk of CVD with grain sources, some evidence for a reduction with vegetable sources, but little suggestion that fruit sources are associated with reduced risk. Too few studies have explored the association with legume sources to permit conclusions to be drawn. With regard to risk of type 2 diabetes incidence, as with CVD risk, the evidence is most conclusive for a reduction in risk with grain sources, rather than fruit or vegetable sources.

There are multiple potential mechanisms through which sources of dietary fibre may make an impact on CVD risk, and data from intervention studies have provided evidence of effects via impact on CVD risk factors, including reduction in blood pressure and blood lipids. However, the majority of trials exploring CVD risk factors have utilised dietary fibre isolates, such as gums, brans and other fibre extracts rather than investigating the effects of food sources per se. Obesity is a well-recognised risk factor for increasing risk of CVD; however, despite some evidence of increased satiety with consumption of certain viscous types of dietary fibre, there is a lack of definitive evidence that particular sources of dietary fibre make an impact differentially on energy intake or body weight, at least in the short term. Longer-term observational studies are supportive of a greater impact of grain sources of dietary fibre rather than fruit and vegetable sources, but as with all observational study associations there remains uncertainty around whether the links exist due to associated lifestyle correlates, such as greater levels of physical activity or another property of the high fibre sources such as displacement of high-energy foods.

\section{Summary of the evidence on total dietary fibre and sources} of fibre on gastrointestinal health

Human feeding studies indicate that fruit, vegetable and grain sources are all effective at increasing faecal weight, with the greatest benefits being achieved from grain and vegetable sources. Data on constipation risk or alleviation of symptoms of constipation are more sparse, but generally supportive of the feeding trials which found that vegetable sources of fibre have a strong impact on faecal weight. In terms of gastrointestinal tract disease, diverticular disease risk appears to be lower in high fibre consumers generally, and particularly in those obtaining fibre from grain and fruit sources. With regard to cancers of the gastrointestinal tract, the evidence base is strongest for cancers of the colon and rectum, and here there is evidence suggestive of a causal association with both total and particularly grain sources of dietary fibre, the latter particularly so for cancers of the rectum and for the precursor lesion, colorectal adenoma. Fewer prospective cohort studies have been conducted on the risk of oesophageal and gastric cancers, but there is some evidence of a lower risk of these neoplastic diseases in higher total fibre consumers and some indication that grain and vegetable sources of dietary fibre are beneficial.

Summary of the evidence on total dietary fibre, sources of fibre and neoplastic disease of non-gastrointestinal sites

Overall, the evidence relating dietary fibre and fibre sources to the risk of neoplastic diseases at sites other than the gastrointestinal tract is weak. This is because generally fewer studies have been conducted, and meta-analyses are therefore based on smaller numbers of studies and often include both prospective cohort as well as case-control studies, with the inherent risk of respondent bias in dietary reporting. Results are generally less consistent or based on too few studies on which to base an opinion. However, there does seem to be some evidence of a lower risk of breast cancer with increasing TDF consumption, but little evidence of a substantially greater risk reduction by source or type of dietary fibre.

\section{Discussion}

This project set out to provide the current state of knowledge about the definitions, sources, recommendations, intakes and health effects of dietary fibre around Europe. Overall, through much searching of national websites and Government publications, as well as the refereed published literature, a comprehensive overview of the state of fibre knowledge has been acquired, which may be of use to researchers or authorities looking to review or revise guidelines on dietary fibre in their respective countries or overall in Europe. A recent review of health effects of carbohydrates published by the SACN in the $\mathrm{UK}^{(34)}$ has been particularly helpful for summarising the situation regarding health effects and this plus the WCRF report from 2007, plus updates, dispensed with the need to carry out a review of the original literature of the relationships between fibre and health. Other aspects of the review, however, required considerable searching of websites and contact with authorities to find up-to-date information about definitions and analyses used, recommendations, health claims, and intakes from national surveys. The work has been a joint effort of all the authors, each undertaking a different aspect of the review and analysis.

In terms of definitions, there is now substantial agreement throughout the world to include within the dietary fibre definition, intrinsic and non-digestible carbohydrates from fruit, vegetables, cereals and tubers and non-digestible compounds associated with cell walls and quantified by most accepted analytical methods, as well as non-digestible carbohydrates obtained by synthesis or modified by enzymic, chemical or physical means when scientific evidence of beneficial physiological effects on health is provided. There is still discussion about whether or not to include RO (non-digestible) of degree of polymerisation 3-11, intrinsic to plant foods or obtained by extraction, synthesis or modified by enzymic, chemical or physical means. While perfect uniformity would be desirable, this is a step forward from earlier decades when the definition of dietary fibre occupied many hours of debate at scientific conferences and extensive commentary in the literature.

Depending on their degree of polymerisation, chemical composition and linkages, dietary fibre sources have varying physicochemical characteristics, such as solubility and viscosity and physiological properties, including fermentability, bulking effects, blood glucose-lowering and blood lipid-modifying effects which can explain their beneficial impacts on health. However, there remain huge gaps in our knowledge about the 
relationships between the chemical and physical characteristics of dietary fibre types and their physiological properties to be able to explain their effects on disease risk. In other words, the mechanistic links between the chemistry and physical nature of fibre and the subsequent impacts on health remain underexplored and there is a great need to fill these gaps in our understanding. There is also a need for adequate characterisation (qualitative and quantitative) in food composition databases of all fibre sources used in nutrition research. This would allow correct estimates of fibre intakes, so recommendations about types of fibre to consume could be based on much firmer evidence than is currently possible.

Throughout Europe the recommendation for total fibre intake is about $3-4 \mathrm{~g} / \mathrm{MJ}$ per $\mathrm{d}$, corresponding to $25-32 \mathrm{~g} / \mathrm{d}$ for adult women and $30-35 \mathrm{~g} / \mathrm{d}$ for adult men, and less for children and elderly depending on age. Most countries have developed their recommendations on an amount per $\mathrm{MJ}$ and extrapolated to $\mathrm{g} / \mathrm{d}$. This is partly due to the reasoning used in developing the recommendations in terms of the disease entities considered. Some have used CHD as the main disease examined, while other countries, most specifically the UK, developed their recommendation on the effect on colonic function which is unrelated to energy intake and hence the amount recommended does not vary with energy intake nor by sex. As mentioned by the EFSA Panel on Dietetic Products, Nutrition and Allergies ${ }^{(86)}$, a fibre intake of $25 \mathrm{~g} / \mathrm{d}$ would be adequate for normal laxation in adults (and $2 \mathrm{~g} / \mathrm{MJ}$ in children) whereas more than $25 \mathrm{~g} / \mathrm{d}$ would be necessary to reduce risk of CHD, type 2 diabetes and improved weight maintenance. Fibre recommendations based on energy intake result in larger amounts needed by young males compared with females and lesser amounts for older adults who consume less energy, but this may or may not be appropriate. A clear challenge to a recommendation based on energy can be seen in the requirements in older age where more fibre may be needed to compensate for impaired gastrointestinal function with age. Some examination of the recommendations based on energy intake is therefore warranted and is further emphasised by the fact that in most countries fibre intakes did not reach the recommended average intakes and in many cases were a long way distant. This is particularly the case where the recommendation is high because of the energy intake it accompanies. It has also been found in some surveys where multiple age groups have been studied that intakes of dietary fibre match the recommendations more closely in some age groups and this may simply be because energy intakes are lower in that group. It may therefore be worthwhile to re-examine fibre recommendations set as a function of energy and in particular recommendations for older age.

No recommendations were found for intake of specific fibre types in any countries. However, approved health claims on fibre-containing foods in the EU would suggest that an intake of the naturally occurring $\beta$-glucans from oats and barley of $3 \mathrm{~g} / \mathrm{d}$, wheat fibre/arabinoxylan of $10 \mathrm{~g} / \mathrm{d}$, pectin of $6 \mathrm{~g} / \mathrm{d}$, and $\mathrm{RS}$ replacing $14 \%$ of total starch could be recommended. However, these amounts would largely be difficult to achieve through foods with naturally occurring fibre content. What also needs to be taken into consideration is that the health claims permitted for several materials are for the same physiological effect or health benefit. Such is the case for $4 \mathrm{~g}$ glucomannan per $\mathrm{d}, 3 \mathrm{~g}$ chitosan per $\mathrm{d}$, and $10 \mathrm{~g}$ guar gum per $\mathrm{d}-$ and hence they need not each be eaten daily or a combination at lower doses should suffice. Evidence of the benefits of these various types could be incorporated into more detailed health advice for dietary fibre consumption from foods, but again this is difficult without the links between chemistry, physical properties and physiological effects.

Very few data on intakes of types of fibre were located from the surveys and studies examined. Only epidemiological studies using FFQ report intakes of soluble and insoluble fibre but this method of assessment of intake is more prone to measurement error than detailed methods and hence was not considered in the intakes examined for this review. The subdivision into soluble and insoluble fibre also has many difficulties, such as methodological variation and lack of consistent association between physiological effects and solubility and has received minimal acceptance as a useful measure. Other physical characteristics, such as viscosity, are difficult to measure and unsuitable for mixed sources of fibre, as in common foods. As a result, and in the absence of a reliable and universally accepted measure to subdivide fibre into different types, food sources that provide the fibre have been used to obtain estimates of fibre quality.

A number of surveys have reported the contribution from the major sources of dietary fibre in the diet. Unfortunately, these are not all directly comparable with different foods in different categories in different countries. Some uniformity exists and hence some general statements about quality can be made. Grain products provide the largest proportion of fibre in the diet for all countries studied, with bread by far the largest grain source, with smaller contributions from breakfast cereals, pasta and biscuits and pastries. Vegetables, potatoes and fruits also contribute substantially, but these vary more widely from country to country, depending on climate and cultural norms. Recommendations about types of fibre to consume are therefore difficult as 'not one size fits all', with some foods more likely to be consumed in some countries compared with others. What is needed are recommendations with alternatives which provide similar fibre quality, based on physiological properties such as fermentability or SCFA pattern when fermented, or physicochemical effects in the small intestine, and their effect on type 2 diabetes mellitus and cardiometabolic health, to enable a more uniform set of recommendations which could cover many countries with differing dietary habits. With such limited information about types of fibre and their comparative physical properties and physiological effects, however, such a scheme is currently not possible.

Without a subdivision of fibre by chemical or physiological characteristics, recommendations based on type are best indicated by examination of food sources, both in terms of those consumed by high fibre consumers and those shown to be related to improved health outcomes and reduced disease risk. One way to examine this is to explore differences in sources of fibre between those who consume adequate fibre and meet the recommendations $v$. those who do not. In studies from Ireland, it has been found that those who meet the fibre recommendation in absolute terms, that is in $\mathrm{g} / \mathrm{d}$, tend to consume more 
food overall than those who do not ${ }^{(87)}$. This confirms the suggestion that guidance to reduce energy intake for obesity concerns is likely to result in reduced fibre intake, and emphasises the need for increased energy expenditure to enable not only higher energy intakes but higher intakes of other necessary nutrients, such as fibre. In another analysis from the same group, in a survey of Irish teenagers, it was also found that consumption of most foods containing fibre was higher in those meeting the recommendation, but more so fruit and vegetables, rather than staples like potatoes, which appear to have a daily limit in consumption ${ }^{(88)}$. It is surprising that more analysis of this type has not been done, that is examination of the diets of those who actually reach recommendations in various countries and it would be very extremely helpful in providing insights into how recommended intakes might be achieved.

Considering the evidence on associations between dietary fibre, dietary fibre sources and disease outcomes, it is apparent that although there are benefits from consumption of all sources of fibre, associations and degree of protection conferred are generally greater for grains. Grain sources of fibre are not all equivalent, however, and there are marked differences in composition between wheat, rye, oat and rice and this may explain some of the heterogeneity between studies and for those conducted in different parts of the world with different grain consumption patterns. Some of this apparent benefit may, however, be an artifact of methodological aspects of dietary assessment such as potentially less measurement error for grains than for fruit and vegetables or the quantitatively greater amounts consumed compared with other fibre sources. There is a need for more evidence on legume sources of dietary fibre and health outcomes. Intervention studies suggest that legume fibre may have an impact on short-term health outcomes including glycaemia and blood lipids, but there is less evidence available of long-term association of legume-based diets with health, perhaps because of low consumption levels or inadequacies of dietary assessment methods to capture these small amounts.

In summary, there is now a fair degree of uniformity in the definition of dietary fibre, the method used for analysis, the recommended amount to be consumed and a growing literature on the effects of fibre and food sources of fibre on digestive health and disease risk. However, intakes do not reach recommendations and there remains little detailed guidance on the types of fibre that are preferable and the types of foods that should be eaten to achieve the recommended intake and have the beneficial health outcomes that fibre is purported to bring about. More detailed advice about the food sources of fibre that should be consumed is needed and efforts should be made to provide the public with such advice. This paper has provided a number of areas where further work may provide additional information to enable such guidance to be given. In particular, in-depth analysis of dietary intakes to understand how those who meet recommendations do so would be extremely useful to aid public health guidance to increase fibre intake.

\section{Acknowledgements}

The present review was conducted by an expert group of the European branch of the International Life Sciences Institute
(ILSI Europe). This publication was coordinated by L. v. L., Scientific Project Manager at ILSI Europe.

The expert group or their institute received funding from the ILSI Europe Nutrient Intake Optimisation Task Force. Industry members of this task force are listed on the ILSI Europe website (www.ilsi.eu). For further information about ILSI Europe, please email info@ilsieurope.be or call +32 277100 14. The opinions expressed herein and the conclusions of this publication are those of the authors and do not necessarily represent the views of ILSI Europe or those of its member companies.

All authors commented on the final manuscript but each section had a main author who wrote the first draft, as follows:

M. M.-J. C. - definitions, classifications and analytical methods; H. M. - recommendations, guidelines and health claims; A. M. S - intakes, abstract, introduction and discussion; V. J. B. health effects

S. J. C. is an employee of Kellogg Company. M. F. is an employee of Nestlé Research Foundation.

\section{References}

1. Agence nationale française de sécurité sanitaire des aliments (ANSES) (2013) French food composition table Ciqual. French Agency for Food, Environmental and Occupational Health Safety. https://pro.anses.fr/tableciqual/ index.htm (accessed October 2015).

2. WHO/FAO (2009) Report of the 30th session of the Codex Committee on Nutrition and Foods for Special Dietary Uses, no. ALINORM 02/32/26. http://www.codexalimentarius. org/input/download/report/710/al32_26e.pdf (accessed October 2015).

3. Agence Française de Sécurité Sanitaire des Aliments (AFSSA) (2002) Dietary Fibre: Definitions, Analysis and Nutrition Claims. Report of the Specialist Expert Committee on Human Nutrition. Maisons-Alfort, France: AFSSA.

4. American Association of Cereal Chemists Fiber Committee (2001) The definition of dietary fiber: Report of the Dietary Fiber Definition Committee to the Board of Directors of the American Association of Cereal Chemists. Cereal Foods World 46, 112-126.

5. Food Standards Australia New Zealand (FSANZ) (2013) Australia New Zealand Food Standards Code - Standard 1.2.7 - Nutrition Health and Related Claims. https://www. comlaw.gov.au/Series/F2013L00054 (accessed October 2015).

6. Health Canada (2012) Policy for Labelling and Advertising of Dietary Fibre-Containing Food Products. http://www. hc-sc.gc.ca/fn-an/legislation/pol/fibre-label-etiquetage-eng. php (accessed October 2015).

7. Institute of Medicine (2005) Dietary Reference Intakes for Energy, Carbohydrate, Fiber, Fat, Fatty Acids, Cholesterol, Protein, and Amino Acids (Macronutrients). Washington, DC: National Academies Press.

8. European Commission (2012) Guidance document for competent authorities for the control of compliance with EU legislation On: Council Directive 90/496/EEC of 24 September 1990 on nutrition labelling of foodstuffs. https://ec.europa.eu/ food/sites/food/files/safety/docs/labelling_legislation_ guidance_methods_2012_en.pdf (accessed October 2015).

9. Asp NG (2001) Development of dietary fibre methodology. In Advanced Dietary Fibre Technology, pp. 77-86 [B McCleary and L Prosky, editors]. London: Blackwell Science Ltd. 
10. McCleary BV, DeVries JW, Rader JI, et al. (2012) Determination of insoluble, soluble, and total dietary fiber (CODEX definition) by enzymatic-gravimetric method and liquid chromatography: collaborative study. J AOAC Int $\mathbf{9 5}$, 824-844.

11. EFSA Panel on Dietetic Products, Nutrition and Allergies (NDA) (2010) Scientific Opinion on Dietary Reference Values for fats, including saturated fatty acids, polyunsaturated fatty acids, monounsaturated fatty acids, trans fatty acids, and cholesterol. EFSA J 8, 1461

12. EFSA Panel on Dietetic Products, Nutrition and Allergies (NDA) (2009) Scientific Opinion on the substantiation of health claims related to dietary fibre and maintenance of normal blood cholesterol concentrations (ID 747, 750, 811) pursuant to Article 13 (1) of Regulation (EC) No 1924/2006. EFSA J 7, 1255.

13. EFSA Panel on Dietetic Products, Nutrition and Allergies (NDA) (2010) Scientific Opinion on the substantiation of health claims related to dietary fibre (ID 744, 745, 746, 748, $749,753,803,810,855,1415,1416,4308,4330)$ pursuant to Article 13(1) of Regulation (EC) No 1924/2006. EFSA J 8, 1735.

14. Stephen AM (1979) Water holding by dietary fibre in vitro and its relationship to faecal bulking in man. Gut 20, 722-729.

15. Marteau P, Flourié B, Cherbut C, et al. (1994) Digestibility and bulking effect of ispaghula husks in healthy humans. Gut 35, 1747-1752.

16. Monro JA (2004) Adequate intake values for dietary fibre based on faecal bulking indexes of 66 foods. Eur J Clin Nutr 58, 32-39.

17. Ranhotra GS, Gelroth JA, Glaser BK, et al. (1991) Fecal bulking effect of whole grain flour from selected grains. Cereal Chem 68, 556-558.

18. Cummings JH (2001) The effect of dietary fiber on fecal weight and composition. In CRC Handbook of Dietary Fiber in Human Nutrition, pp. 183-252 [GA Spiller, editor]. Boca Raton, FL: CRC Press.

19. EFSA Panel on Dietetic Products, Nutrition and Allergies (NDA) (2011) Scientific Opinion on the substantiation of health claims related to xanthan gum and changes in bowel function (ID 837) pursuant to Article 13(1) of Regulation (EC) No 1924/2006. EFSA J 9, 2272.

20. European Parliament (2006) Regulation (EC) No. 1924/2006 of the European Parliament and of the Council of 20 December 2006 on nutrition and health claims made on foods. Official Journal of the European Union vol. 404, 9. http://eur-lex.europa.eu/legal-content/EN/TXT/?uri=CELEX: 02006R1924-20121129 (accessed October 2015).

21. De Vries JW (2000) Analytical issues regarding the regulatory aspects of dietary fibre nutrition labelling. In Advanced Dietary Fibre Technology, pp. 123-138 [BV McCleary and L Prosky, editors]. London: Blackwell Science.

22. Southgate DA (1969) Determination of carbohydrates in foods. II. Unavailable carbohydrates. J Sci Food Agric 20, 331-335.

23. Englyst HN, Anderson V \& Cummings JH (1983) Starch and non-starch polysaccharides in some cereal foods. J Sci Food Agric 34, 1434-1440.

24. Englyst HN \& Kingman S (1987) Dietary fiber and resistant starch. In Dietary Fiber: Chemistry, Physiology, and Health Effects, pp. 49-65 [D Kritchevsky, CT Bonfield and J Anderson, editors]. New York: Springer US.

25. Englyst HN, Quigley ME, Hudson GJ, et al. (1992) Determination of dietary fibre as non-starch polysaccharides by gas-liquid chromatography. Analyst 117, $1707-1714$.
26. Theander O, Aman P, Westerlund E, et al. (1990) The Uppsala method for rapid analysis of total dietary fiber. Adv Exp Med Biol 70, 273-281.

27. Theander O (1995) Total dietary fiber determined as neutral sugar residues, uronic acid residues, and Klason lignin (the Uppsala method): collaborative study. J $A O A C$ Int 78, 1030-1044.

28. Scientific Advisory Committee of Nutrition (2013) SACN draft position statement on dietary fibre. https://www.gov.uk/ government/uploads/system/uploads/attachment_data/file/ 339771/Draft_SACN_Carbohydrates_and_Health_report_ consultation.pdf (accessed October 2015).

29. European Commission (2014) Register of nutrition and health claims made on foods. http://ec.europa.eu/nuh claims/ (accessed October 2015).

30. US Food and Drug Administration (2015) Guidance for Industry: A Food Labeling Guide. Appendix C: Health Claims. http://www.fda.gov/Food/GuidanceRegulation/ GuidanceDocumentsRegulatoryInformation/LabelingNutrition/ ucm064919.htm (accessed October 2015).

31. Australian National Health and Medical Research Council (2006) Nutrient Reference Values for Australia and New Zealand Including Recommended Dietary Intakes. https:// www.nhmrc.gov.au/_files_nhmrc/publications/attachments/ n35.pdf (accessed October 2015).

32. Dahm CC, Keogh RH, Spencer EA, et al. (2010) Dietary fiber and colorectal cancer risk: a nested case-control study using food diaries. J Natl Cancer Inst 102, 614-626.

33. Sette S, Le Donne C, Piccinelli R, et al. (2011) The third Italian national food consumption survey, INRAN-SCAI 2005 - part 1: nutrient intakes in Italy. Nutr Metab Cardiovasc Dis 21, 922-932.

34. Scientific Advisory Committee on Nutrition (2015) Carbohydrates and Health Report. London: Public Health England.

35. Burkitt DP \& Trowell HC (1977) Dietary fibre and Western diseases. Ir Med J 70, 272-277.

36. World Cancer Research Fund International (2015) Continuous Update Project. http://www.wcrf.org/int/researchwe-fund/continuous-update-project-findings-reports (accessed October 2015).

37. World Cancer Research Fund \& American Institute for Cancer Research (2007) Food, Nutrition, Physical Activity, and the Prevention of Cancer: a Global Perspective. Washington, DC. http://www.wcrf.org/sites/default/files/ Second-Expert-Report.pdf (accessed October 2015).

38. Berlin JA, Longnecker MP \& Greenland S (1993) Metaanalysis of epidemiologic dose-response data. Epidemiology 4, 218-228.

39. Kim Y \& Je Y (2014) Dietary fiber intake and total mortality: a meta-analysis of prospective cohort studies. $\mathrm{Am} \mathrm{J}$ Epidemiol 180, 565-573.

40. Bazzano LA, He J, Ogden LG, et al. (2003) Dietary fiber intake and reduced risk of coronary heart disease in US men and women: the National Health and Nutrition Examination Survey I Epidemiologic Follow-up Study. Arch Intern Med 163, 1897-1904.

41. Pietinen P, Rimm EB, Korhonen P, et al. (1996) Intake of dietary fiber and risk of coronary heart disease in a cohort of Finnish men: The Alpha-Tocopherol, Beta-Carotene Cancer Prevention Study. Circulation 94, 2720-2727.

42. World Health Organization (2003) Joint WHO/FAO Expert Consultation on Diet, Nutrition and the Prevention of Chronic Diseases, no. 916. http://www.who.int/dietphysi calactivity/publications/trs916/en/gsfao_introduction.pdf (accessed October 2015). 
43. Buttriss JL \& Stokes CS (2008) Dietary fibre and health: an overview. Atherosclerosis 33, 186-200.

44. Threapleton DE, Greenwood DC, Evans CE, et al. (2013) Dietary fibre intake and risk of cardiovascular disease: systematic review and meta-analysis. BMJ 347, f6879.

45. Threapleton DE, Greenwood DC, Evans CEL, et al. (2013) Dietary fiber intake and risk of first stroke: a systematic review and meta-analysis. Stroke 44, 1360-1368.

46. Streppel MT, Arends LR, Van't Veer P, et al. (2005) Dietary fiber and blood pressure: a meta-analysis of randomized placebo-controlled trials. Arch Intern Med 165, 150-156.

47. Whelton SP, Hyre AD, Pedersen B, et al. (2005) Effect of dietary fiber intake on blood pressure: a meta-analysis of randomized, controlled clinical trials. J Hypertens 23, 475-481.

48. Evans CE, Greenwood DC, Threapleton DE, et al. (2015) Effects of dietary fibre type on blood pressure: a systematic review and meta-analysis of randomized controlled trials of healthy individuals. J Hypertens 33, 897-911.

49. Brown L, Rosner B, Willett WW, et al. (1999) Cholesterollowering effects of dietary fiber: a meta-analysis. J Hypertens 69, 30-42.

50. Threapleton DE, Greenwood DC, Evans C, et al. (2013) Dietary fibre intake and diabetes risk: a systematic review and meta-analysis of prospective studies. Proc Nutr Soc $\mathbf{7 2}$, E253.

51. Yao B, Fang H, Xu W, et al. (2014) Dietary fiber intake and risk of type 2 diabetes: a dose-response analysis of prospective studies. Eur J Epidemiol 29, 79-88.

52. Haber GB, Heaton KW, Murphy D, et al. (1977) Depletion and disruption of dietary fibre. Effects on satiety, plasmaglucose, and serum-insulin. Lancet ii, 679-682.

53. Clark MJ \& Slavin JL (2013) The effect of fiber on satiety and food intake: a systematic review. J Am Coll Nutr 32, 200-211.

54. Wanders AJ, van den Borne JJ, de Graff C, et al. (2011) Effects of dietary fibre on subjective appetite, energy intake and body weight: a systematic review of randomized controlled trials. Obes Rev 12, 724-739.

55. Lindstrom J, Peltonen M, Eriksson JG, et al. (2006) Highfibre, low-fat diet predicts long-term weight loss and decreased type 2 diabetes risk: the Finnish Diabetes Prevention Study. Diabetologia 49, 912-920.

56. Du H, Boshuizen HC, Forouhi NG, et al. (2010) Dietary fiber and subsequent changes in body weight and waist circumference in European men and women. Am J Clin Nutr 91, 329-336.

57. Peppas G, Alexiou VG, Mourtzoukou E, et al. (2008) Epidemiology of constipation in Europe and Oceania: a systematic review. BMC Gastroenterol 8, 5 .

58. Elia M \& Cummings JH (2007) Physiological aspects of energy metabolism and gastrointestinal effects of carbohydrates. Eur J Clin Nutr 61, Suppl. 1, S40-S74.

59. Dukas L, Willett WC \& Giovannucci EL (2003) Association between physical activity, fiber intake, and other lifestyle variables and constipation in a study of women. $\mathrm{Am} \mathrm{J}$ Gastroenterol 98, 1790-1796.

60. Markland AD, Palsson O, Goode PS, et al. (2013) Association of low dietary intake of fiber and liquids with constipation: evidence from the National Health and Nutrition Examination Survey. Am J Gastroenterol 108, 796-803.

61. Yang J, Wang H-P, Zhou L, et al. (2012) Effect of dietary fiber on constipation: a meta analysis. World J Gastroenterol 18, 7378-7383.

62. Sanjoaquin MA, Appleby PN, Spencer EA, et al. (2004) Nutrition and lifestyle in relation to bowel movement frequency: a cross-sectional study of 20630 men and women in EPIC-Oxford. Public Health Nutr 7, 77-83.

63. Alrefaai L, Cade JE \& Burley VJ (2013) Dietary fibre intake and constipation in the UK Women's Cohort Study. Proc Nutr Soc 72, E287.

64. Painter NS \& Burkitt DP (1971) Diverticular disease of the colon: a deficiency disease of Western civilization. Br Med J 2, 450-454.

65. Aldoori WH, Giovannucci EL, Rimm EB, et al. (1994) A prospective study of diet and the risk of symptomatic diverticular disease in men. Am J Clin Nutr 60, 757-764.

66. Crowe FL, Appleby PN, Allen NE, et al. (2011) Diet and risk of diverticular disease in Oxford cohort of European Prospective Investigation into Cancer and Nutrition (EPIC): prospective study of British vegetarians and nonvegetarians. BMJ 343, d4131.

67. Crowe FL, Balkwill A, Cairns BJ, et al. (2014) Source of dietary fibre and diverticular disease incidence: a prospective study of UK women. Gut 63, 1450-1456.

68. Coleman HG, Murray LJ, Hicks B, et al. (2013) Dietary fiber and the risk of precancerous lesions and cancer of the esophagus: a systematic review and meta-analysis. Nutr Rev 71, 474-482.

69. Zhang Z, Xu G, Ma M, et al. (2013) Dietary fiber intake reduces risk for gastric cancer: a meta-analysis. Gastroenterology 145, 113-120.

70. World Cancer Research Fund/American Institute for Cancer Research (2011) Continuous Update Project Report. Food, Nutrition, Physical Activity, and the Prevention of Colorectal Cancer. http://www.dietandcancerreport.org/cancer_ resource_center/downloads/cu/Colorectal-Cancer-2011Report.pdf (accessed October 2015).

71. Aune D, Chan DSM, Lau R, et al. (2011) Dietary fibre, whole grains, and risk of colorectal cancer: systematic review and dose-response meta-analysis of prospective studies. BMJ 343, d6617.

72. Murphy N, Norat T, Ferrari P, et al. (2012) Dietary fibre intake and risks of cancers of the colon and rectum in the European prospective investigation into cancer and nutrition (EPIC). PLOS ONE 7, e39361.

73. Ben Q, Sun Y, Chai R, et al. (2014) Dietary fiber intake reduces risk for colorectal adenoma: a meta-analysis. Gastroenterology 146, 689

74. Aune D, Chan DSM, Greenwood DC, et al. (2012) Dietary fiber and breast cancer risk: a systematic review and metaanalysis of prospective studies. Ann Oncol 23, 1394-1402.

75. Kaaks R, Lukanova A \& Kurzer MS (2002) Obesity, endogenous hormones, and endometrial cancer risk: a synthetic review. Cancer Epidemiol Biomarkers Prev 11, 1531-1543.

76. Hjartaker A, Langseth H \& Weiderpass E (2008) Obesity and diabetes epidemics: cancer repercussions. $A d v$ Exp Med Biol 630, 72-93.

77. Cust AE, Slimani N, Kaaks R, et al. (2007) Dietary carbohydrates, glycemic index, glycemic load, and endometrial cancer risk within the European Prospective Investigation into Cancer and Nutrition cohort. Am J Epidemiol 166, 912-923.

78. Bandera EV, Kushi LH, Moore DF, et al. (2007) Association between dietary fiber and endometrial cancer: a doseresponse meta-analysis. Am J Clin Nutr 86, 1730-1737.

79. Jain MG, Rohan TE, Howe GR, et al. (2000) A cohort study of nutritional factors and endometrial cancer. Eur $J$ Epidemiol 16, 899-905.

80. Howe GR, Jain M \& Miller AB (1990) Dietary factors and risk of pancreatic cancer: results of a Canadian populationbased case-control study. Int J Cancer 45, 604-608. 
81. Silverman DT, Swanson CA, Gridley G, et al. (1998) Dietary and nutritional factors and pancreatic cancer: a casecontrol study based on direct interviews. J Natl Cancer Inst 90, 1710-1719.

82. Norat T, Aune D, Rosenblatt DN, et al. (2013) WCRF/AICR Systematic Literature Review Continuous Update Project Report. Food, Nutrition, Physical Activity, and the Prevention of Ovarian Cancer. http://www.wcrf.org/sites/default/ files/ovarian-cancer-slr-2013.pdf (accessed October 2015).

83. Ferlay J, Parkin DM \& Steliarova-Foucher E (2010) Estimates of cancer incidence and mortality in Europe in 2008. Eur J Cancer 46, 765-781.

84. Ljungberg B, Campbell SC, Cho HY, et al. (2011) The epidemiology of renal cell carcinoma. Eur Urol 60, 615-621.

85. Huang TB, Ding PP, Chen JF, et al. (2014) Dietary fiber intake and risk of renal cell carcinoma: evidence from a meta-analysis. Med Oncol 31, 125.

86. EFSA Panel on Dietetic Products, Nutrition and Allergies (NDA) (2010) Scientific Opinion on the substantiation of health claims related to konjac mannan (glucomannan) and reduction of body weight (ID 854, 1556, 3725), reduction of post-prandial glycaemic responses (ID 1559), maintenance of normal blood glucose concentrations (ID 835, 3724), maintenance of normal (fasting) blood concentrations of triglycerides (ID 3217), maintenance of normal blood cholesterol concentrations (ID 3100, 3217), maintenance of normal bowel function (ID 834, 1557, 3901) and decreasing potentially pathogenic gastro-intestinal microorganisms (ID 1558) pursuant to Article 13(1) of Regulation (EC) No 1924/2006. EFSA J 8, 1798-1825.

87. Galvin MA, Kiely M, Harrington KE, et al. (2001) The North/ South Ireland Food Consumption Survey: the dietary fibre intake of Irish adults. Public Health Nutr 4, 1061-1068.

88. Bannon S, Walton J \& Flynn A (2010) Dietary patterns influencing dietary fibre intake in Irish teenagers aged 13-7 years. Proc Nutr Soc 69, E375.

89. European Commission (2008) Commission Directive 2008/ 100/EC of 28 October 2008 amending Council Directive 90/ 496/EEC on nutrition labelling for foodstuffs as regards recommended daily allowances, energy conversion factors and definitions. Off J Eur Union 51, 9-12.

90. Martin A (2001) Apports nutritionnels conseillés pour la population française (Recommended Nutritional Intakes for the French Population). Paris: Tec \& Doc Lavoisier.

91. Federal Register (2014) Food labeling: revision of the nutrition and supplement facts labels; proposed rule. Fed Regis 79, 11879-11987.

92. Kumar V, Sinha AK, Makkar HP, et al. (2012) Dietary roles of non-starch polysaccharides in human nutrition: a review. Crit Rev Food Sci Nutr 52, 899-935.

93. Li BW, Andrews KW \& Pehrsson PR (2002) Individual sugars, soluble, and insoluble dietary fiber contents of 70 high consumption foods. J Food Comp Anal 15, 715-723.

94. Mayer F (1998) Potato pulp: properties, physical modification and applications. Polym Degrad Stab 59, 231-235.

95. Nyman M, Siljestrom M, Pedersen B, et al. (1984) Dietary fiber content and composition in six cereals at different extraction rates. Cereal Chem 61, 14-19.

96. Agence Française de Sécurité Sanitaire des Aliments (2008) Avis de l'Agence française de sécurité sanitaire des aliments relatif à l'évaluation d'une demande d'autorisation de mise sur le marché d'un nouvel aliment ou d'un nouvel ingrédient alimentaire : téguments (ou cosses) de psyllium issues de Plantago ovata, no. 2008-SA-0148 (Opinion of the French Food Safety Agency on the assessment of an application for a marketing authorization for a novel food or a new food ingredient: psyllium teguments (or pods) derived from Plantago ovata, no. 2008-SA-0148). https:// www.anses.fr/fr/system/files/NUT2008sa0148.pdf (accessed October 2015).

97. Agence Française de Sécurité Sanitaire des Aliments (2003) Avis de l'Agence relatif à l'évaluation du polydextrose en tant qu'ingrédient et fibre destinée à l'alimentation humaine et à l'évaluation des justificatifs des allégations proposées relatives au transit intestinal, no. 2003-SA-0232 (Opinion of the Agency on the evaluation of polydextrose as an ingredient and fibre for food and on the evaluation of the evidence of proposed intestinal transfusion claims, no. 2003-SA-0232). https://www.anses.fr/fr/system/files/NUT 2002sa0183.pdf (accessed October 2015).

98. Agence Française de Sécurité Sanitaire des Aliments (2005) Avis relatif à une demande d'évaluation de l'allégation 'fibres alimentaires' concernant un amidon résistant de type RS3, no. 2005-SA-0285 (Notice concerning a request for evaluation of the claim 'Dietary fibre' for a resistant starch of type RS3, no. 2005-SA-0285). https://www.anses.fr/fr/ system/files/NUT2005sa0285.pdf (accessed October 2015).

99. Agence Française de Sécurité Sanitaire des Aliments (2002) Avis relatif à une demande d'évaluation sur l'emploi, dans des compléments alimentaires, de la gomme de guar (actuellement considérée comme additif technologique conformément à l'arrêté du 2 octobre 1997), en tant qu'additif à but nutritionnel, no. 2002-SA-0070 (Notice on a request for an evaluation of the use of guar gum in food supplements (currently considered as a technological additive in accordance with the Order of 2 October 1997), as a nutritional supplement, no. 2002-SA-0070). https://www.anses.fr/fr/ system/files/NUT2002sa0070.pdf (accessed October 2015).

100. Agence Française de Sécurité Sanitaire des Aliments (2009) Avis de l'Agence française de sécurité sanitaire des aliments relatif à l'évaluation de la demande de mise sur le marché d'un nouvel ingrédient alimentaire, la gomme de guar, no. 2009-SA-0214 (Opinion of the French Food Safety Agency on the assessment of the application for the placing on the market of a novel food ingredient, guar gum, no. 2009SA-0214). https://www.anses.fr/fr/system/files/NUT2009 sa0214.pdf (accessed October 2015).

101. Agence Française de Sécurité Sanitaire des Aliments (2007) Avis de l'Agence française de sécurité sanitaire des aliments relatif à la demande d'évaluation du fondement scientifique de l'allégation relative à l'effet des fibres solubles d'avoine consommées au sein d'un régime adapté sur le cholestérol sanguin, no. 2007-SA-0168 (Opinion of the French Food Safety Agency on the request for an assessment of the scientific basis for the claim concerning the effect of soluble oat fibre consumed in a suitable diet on blood cholesterol, no. 2007-SA-0168). https://www.anses.fr/fr/system/files/ NUT2007sa0168.pdf (accessed October 2015).

102. Agence Française de Sécurité Sanitaire des Aliments (2002) Avis de l'Agence relatif à l'évaluation du polydextrose en tant qu'ingrédient et fibre destinée à l'alimentation humaine et à l'évaluation des justificatifs des allégations proposées relatives au transit intestinal, no. 2002-SA-0183 (Opinion of the Agency on the evaluation of polydextrose as an ingredient and fibre for food and on the evaluation of the evidence of proposed intestinal transfusion claims, no. 2002-SA-0183). https://www.anses.fr/fr/system/files/ NUT2002sa0183.pdf (accessed October 2015).

103. Agence Française de Sécurité Sanitaire des Aliments (2003) Avis relatif à une demande d'évaluation de la consommation d'un amidon résistant de type RS3 par le biais de 
l'alimentation courante traditionnelle afin de conclure sur le recul de consommation de cet amidon (en vue d'une évaluation éventuelle au titre du règlement $n^{\circ} 97 / 258$ ), no. 2003-SA-0162 (Opinion on a request to evaluate the consumption of a resistant starch of the RS3 type by means of traditional traditional feedingstuffs in order to conclude on the decline in consumption of this starch (with a view to a possible evaluation under Regulation No 97/258), no. 2003-SA-0162). https://www.anses.fr/fr/system/files/NUT 2003sa0162.pdf (accessed October 2015).

104. Agence nationale de sécurité sanitaire de l'alimentation, de l'environnement et du travail (ANSES) (2011) Avis de l'Agence relatif à une demande d'avis relatif à l'innocuité de l'emploi de fibres prébiotiques constituées d'un mélange équipondéral de galacto-oligosaccharides et de polydextrose dans une préparation pour nourrissons, no. 2011-SA-0173 (Opinion of the Agency on a request for an opinion on the safety of the use of prebiotic fibres consisting of a mixture of equivalents of galacto-oligosaccharides and polydextrose in an infant formula, no. 2011-SA-0173). https://www.anses.fr/ fr/system/files/NUT2011sa0173.pdf (accessed October 2015).

105. EFSA Panel on Dietetic Products, Nutrition and Allergies (NDA) (2010) Scientific Opinion on Dietary Reference Values for fats, including saturated fatty acids, polyunsaturated fatty acids, monounsaturated fatty acids, trans fatty acids, and cholesterol. European Food Safety Authority. http://orbit.dtu.dk/en/publications/efsa-panel-on-dieteticproducts-nutrition-and-allergies-nda-scientific-opinion-ondietary-reference-values-for-fats-including-saturated-fattyacids-polyunsaturated-fatty-acids-monounsaturated-fatty-acidstrans-fatty-acids-and-cholesterol(509e2df6-f374-4b9d-b3e09be568c3a15c).html (accessed October 2015).

106. EFSA (2011) Scientific Opinion on the substantiation of health claims related to arabinoxylan produced from wheat endosperm and reduction of post-prandial glycaemic responses (ID 830) pursuant to Article 13(1) of Regulation (EC) No 1924/2006. EFSA J 9, 2205.

107. Lin Y, Huybrechts I, Vandevijvere S, et al. (2011) Fibre intake among the Belgian population by sex-age and sex-education groups and its association with BMI and waist circumference. Br J Nutr 105, 1692-1703.

108. Vaask S, Liebert T, Maser M, et al. (2006) Estonian Nutrition and Food Recommendations. Tallinn: Estonian Society of Nutritional Science, National Institute for Health Development.

109. European Food Safety Authority (2010) Scientific Opinion on Dietary Reference Values for carbohydrates and dietary fibre. EFSA J 8, 1462.

110. Deutsche Gesellschaft für Ernährung (DGE), Österreichische Gesellschaft für Ernährung (ÖGE) \& Schweizerische Gesellschaft für Ernährung (SGE) (2008) Referenzwerte für die Nährstoffzufubr (Reference Values for Food Nutrients). Frankfurt am Main: German Nutrition Society (DGE), Austrian Nutrition Society (ANS) and Swiss Society for Nutrition (SGE).

111. Rodler I (editor) (2005) Új tápanyagtáblázat (New Nutritional Table). Budapest: Medicina Könyvkiadó.

112. Cho SS, O'Sullivan K \& Rickard S (1987) Worldwide dietary fiber intake: recommendations and actual consumption patterns. In Complex Carbohydrates in Foods, 10th ed., pp. 71-111 [OR Fennema, YH Hui, M Karel, P Walstra and JR Whitaker, editors]. New York: Marcel Dekker.

113. Società Italiana di Comunicazione Scientifica e Sanitaria (2012) Livelli di Assunzione di Riferimento di Nutrienti ed energia per la popolazione italiana. Sintesi prefinale (Reference Levels of Nutrients and Energy Intake for the Italian Population. Pre-final Synthesis). Milan: Società Italiana di Comunicazione Scientifica e Sanitaria.
114. Health Council of the Netherlands (2001) Dietary Reference Intakes: Energy, Proteins, Fats and Digestible Carbohydrates, no. 2001/19R. The Hague: Health Council of the Netherlands.

115. Health Council of the Netherlands (2006) Guideline for Dietary Fiber Intake, no. 2006/03. The Hague: Health Council of the Netherlands.

116. Nordic Nutrition Recommendations (2012) Integrating Nutrition and Physical Activity, no. Nord 2014:002. Copenhagen: Nordic Council of Ministers.

117. National Food and Nutrition Institute (2012) Normy zywienia dla populacji polskiej - nowelizacja, IZZ, 2012 (Polish Dietary Reference Intakes - amendments 2012). Warsaw: Instytut Zywnosci i Zywienia (National Food and Nutrition Institute).

118. Graça P (1999) Dietary guidelines and food nutrient intakes in Portugal. Br J Nutr 81, S99-S103.

119. Romanian Society of Diabetes, Nutrition and Metabolic Diseases (2015) Reguli pentru o alimentaţie sănătoasă (Guide for a healthy diet). http://www.fao.org/3/a-as693o.pdf (accessed October 2015)

120. Slovakian Public Health Authority (2015) Public Health Office of the Slovak Republic. http://www.uvzsr.sk (accessed October 2015).

121. German Nutrition Society, Austrian Nutrition Society, Swiss Society of Nutrition Research, et al. (2004) The Reference Values for Nutrient Intake. Ljubljana: Ministry of Health, the Republic of Slovenia.

122. Department of Health (1991) Dietary Reference Values for Food and Energy and Nutrients for the United Kingdom: Report of the Panel on Dietary Reference Values of the Committee on Medical Aspects of Food Policy. London: The Stationery Office.

123. World Health Organization (2003) Diet, Nutrition and the Prevention of Chronic Diseases. Geneva: WHO.

124. European Commission (2013) Commission Regulation (EU) No 536/2013 of 11 June 2013 amending Regulation (EU) No $432 / 2012$ establishing a list of permitted health claims made on foods other than those referring to the reduction of disease risk and to children's development and health. Off J Eur Union 160, 4-8.

125. EFSA (2010) Scientific Opinion on the substantiation of health claims related to guar gum and maintenance of normal blood glucose concentrations (ID 794), increase in satiety (ID 795) and maintenance of normal blood cholesterol concentrations (ID 808) pursuant to Article 13(1) of Regulation (EC) No 1924/2006. EFSA J 8, 1464-1481.

126. EFSA (2012) Scientific Opinion on the substantiation of health claims related to alpha-cyclodextrin and reduction of post-prandial glycaemic responses (ID 2926, further assessment) pursuant to Article 13(1) of Regulation (EC) No 1924/20061. EFSA J 10, 2713-2730.

127. European Commission (2012) Regulations Commission Regulation (EU) No 432/2012 of 16 May 2012 establishing a list of permitted health claims made on foods, other than those referring to the reduction of disease risk and to children's development and health. Off J Eur Union 136, $1-40$.

128. EFSA Panel on Dietetic Products, Nutrition and Allergies (2011) Scientific Opinion on the substantiation of health claims related to oat and barley grain fibre and increase in faecal bulk (ID 819, 822) pursuant to Article 13(1) of Regulation (EC) No 1924/2006. EFSA J 9, 2249.

129. EFSA (2011) Scientific Opinion on health claims already evaluated (ID 215, 568, 674, 712, 1398, 1633, 1974, 4191, 4192, 4193, 4236, 4335, 4698, 4704) pursuant to Article 13(1) of Regulation (EC) No 1924/2006. EFSA J 9, 2203-2225. 
130. EFSA Panel on Dietetic Products, Nutrition and Allergies (2009) Scientific Opinion on the substantiation of health claims related to beta-glucans and maintenance of normal blood cholesterol concentrations (ID 754, 755, 757, 801, $1465,2934)$ and maintenance or achievement of a normal body weight (ID 820, 823) pursuant to Article 13(1) of Regulation (EC) No 1924/2006. EFSA J 7, 1254.

131. EFSA (2011) Scientific Opinion on the substantiation of health claims related to chitosan and reduction in body weight (ID 679, 1499), maintenance of normal blood LDLcholesterol concentrations (ID 4663), reduction of intestinal transit time (ID 4664) and reduction of intestinal transit time (ID 4664) and reduction. EFSA J 9, 2214-2235.

132. EFSA (2009) Scientific Opinion on the substantiation of health claims related to glucomannan and maintenance of normal blood cholesterol concentrations (ID 836, 1560) pursuant to Article 13(1) of Regulation (EC) No 1924/2006. EFSA J 7, 1258-1272.

133. EFSA (2011) Scientific Opinion on the substantiation of health claims related to resistant starch and reduction of post-prandial glycaemic responses (ID 681), "digestive health benefits" (ID 682) and "favours a normal colon metabolism" (ID 783) pursuant to Article 13(1) of Regulation (EC) No 1924/2006. EFSA J 9, 2024-2041.

134. EFSA (2011) Scientific Opinion on the substantiation of health claims related to rye fibre and changes in bowel function (ID 825), reduction of post-prandial glycaemic responses (ID 826) and maintenance of normal blood LDLcholesterol concentrations (ID 827) pursuant to Article 13(1) of Regulation (EC) No 1924/20061. EFSA J 9, 2258-2076.

135. EFSA (2010) Scientific Opinion on the substantiation of health claims related to pectins and reduction of postprandial glycaemic responses (ID 786), maintenance of normal blood cholesterol concentrations (ID 818) and increase in satiety leading to a reduction in energy intake (ID 4692) pursuant to Article 13(1) of Regulation (EC) No 1924/20061. EFSA J 8, 1747-1764.

136. EFSA (2010) Scientific Opinion on the substantiation of health claims related to wheat bran fibre and increase in faecal bulk (ID 3066), reduction in intestinal transit time (ID 828, 839, 3067, 4699) and contribution to the maintenance or achievement of a normal body weight (ID 829) pursuant to Article 13(1) of Regulation (EC) No 1924/2006. EFSA J 8, 1817-1835.

137. European Commission (2014) Commission Regulation (EU) No 40/2014 of 17 January 2014 authorising a health claim made on foods, other than those referring to the reduction of disease risk and to children's development and health and amending Regulation (EU) No 432/2012. Off J Eur Union 14, 8-9.

138. EFSA (2011) Scientific Opinion on the substantiation of a health claim related to sugar beet fibre and increasing faecal bulk pursuant to Article 13(5) of Regulation (EC) No 1924/2006. EFSA J 9, 2468.

139. European Commission (2012) Commission Regulation (EU) No 1048/2012 of 8 November 2012 on the authorisation of a health claim made on foods and referring to the reduction of disease risk. Off J Eur Union 310, 38-40.

140. EFSA (2011) Scientific Opinion on the substantiation of a health claim related to barley beta-glucans and lowering of blood cholesterol and reduced risk of (coronary) heart disease pursuant to Article 14 of Regulation (EC) No 1924/ 2006. EFSA J 9, 2470.

141. EFSA (2011) Scientific Opinion on the substantiation of a health claim related to barley beta-glucans and lowering of blood cholesterol and reduced risk of (coronary) heart disease pursuant to Article 14 of Regulation (EC) No 1924/ 2006. EFSA J 9, 2471.
142. European Commission (2011) Commission Regulation (EU) No 1160/2011 of 14 November 2011 on the authorisation and refusal of authorisation of certain health claims made on foods and referring to the reduction of disease risk. Off J Eur Union 296, 26-28.

143. EFSA (2011) Scientific Opinion on the substantiation of a health claim related to oat beta glucan and lowering blood cholesterol and reduced risk of (coronary) heart disease pursuant to Article 14 of Regulation (EC) No 1924/2006. EFSA J 8, 1885.

144. Code of Federal Regulations (2012) Health claims: fiber-containing grain products, fruits, and vegetables and cancer. https://www.accessdata.fda.gov/scripts/cdrh/ cfdocs/cfcfr/CFRSearch.cfm?fr=101.76 (accessed October 2015).

145. Code of Federal Regulations (2012) Health claims: fruits, vegetables, and grain products that contain fiber, particularly soluble fiber, and risk of coronary heart disease. http:// www.accessdata.fda.gov/scripts/cdrh/cfdocs/cfcfr/cfrsearch. cfm?fr=101.77 (accessed October 2015).

146. Elmadfa I (2009) Austrian Nutrition Report 2008. Vienna: Austrian Federal Ministry of Health. http://aesan.msssi.gob.es/ AESAN/docs/docs/evaluacion_riesgos/Austria.pdf (accessed October 2015).

147. Liu L, Wang PP, Roebothan B, et al. (2013) Assessing the validity of a self-administered food-frequency questionnaire (FFQ) in the adult population of Newfoundland and Labrador, Canada. Nutr J 12, 49.

148. Pederesen A, Fagt S, Groth MV, et al. (2010) Danskernes Kostvaner 2003-2008 (Danish National Survey of Dietary Habits and Physical Activity). Copenhagen: Technical University of Denmark.

149. Pietinen P, Paturi M, Reinivuo $\mathrm{H}$, et al. (2010) FINDIET 2007 Survey: energy and nutrient intakes. Public Health Nutr 13, 920-924.

150. Mikkilä V, Räsänen L, Raitakari OT, et al. (2004) Longitudinal changes in diet from childhood into adulthood with respect to risk of cardiovascular diseases: The Cardiovascular Risk in Young Finns Study. Eur J Clin Nutr 58, 1038-1045.

151. Agence Française de Sécurité Sanitaire des Aliments (2009) Étude Individuelle Nationale des Consommations Alimentaires 2 (INCA 2)(2006-2007) (Individual National Study of Food Consumption 2] (INCA 2) (2006-2007)). https://www. anses.fr/fr/system/files/PASER-Ra-INCA2.pdf (accessed October 2015).

152. Deschasaux M, Pouchieu C, His M, et al. (2014) Dietary total and insoluble fiber intakes are inversely associated with prostate cancer risk. J Nutr 144, 504-510.

153. Max Rubner-Institut Bundesforschungsinstitut für Ernährung und Lebensmittel (2015) Die Nationale Verzehrsstudie II. http://www.mri.bund.de/NationaleVerzehrsstudie (accessed October 2015).

154. Szeitz-Szabó, Bíró L, Bíró G, et al. (2011) Dietary survey in Hungary, 2009. Part I. Macronutrients, alcohol, caffeine, fibre. Acta Alimentaria 40, 142-152.

155. Flynn A, Walton J, Gibney M, et al. (2011) National Adult Nutrition Survey. Cork: Irish Universities Nutrition Alliance (IUNA).

156. Sette S, Le Donne C, Piccinelli R, et al. (2011) The Third Italian National Food Consumption Survey, INRAN-SCAI 2005-06 - part 1: nutrient intakes in Italy. Nutr Metab Cardiovasc Dis 21, 922-932.

157. Nakaji S, Sugawara K, Saito D, et al. (2002) Trends in dietary fiber intake in Japan over the last century. Eur J Nutr 41, 222-227. 
158. Fukuda S, Saito H, Nakaji S, et al. (2007) Pattern of dietary fiber intake among the Japanese general population. Eur $J$ Clin Nutr 61, 99-103.

159. van de Laar RJ, Stehouwer CD, van Bussel BC, et al. (2012) Lower lifetime dietary fiber intake is associated with carotid artery stiffness: the Amsterdam Growth and Health Longitudinal Study. Am J Clin Nutr 96, 14-23.

160. van Rossum C, Fransen H, VerkaikKloosterman J, et al. (2011) Dutch National Food Consumption Survey 20072010: Diet of children and adults aged 7 to 69 years, no. 350050006. Bilthoven: RIVM.

161. Totland TH, Melnaes BK, Lundberg-Hallèn N, et al. (2012) Norkost 3; En landsomfattende kostholdsundersøkelse blant menn og kvinner i Norge i alderen 18-70 år, 201011 (Norkost 3; A nationwide food consumption survey among men and women in Norway aged 18-70 years, 2010-11). Oslo: Helsedirektoratet. http://helsedirektoratetno/publikasjoner/norkost-3-en-landsomfattendekostholdsundersokelse-blant-menn-og-kvinner-i-norge-i-alderen-1870-ar/Publikasjoner/norkost-3-is-2000 pdf (accessed October 2015).

162. Sekula W, Sekula W, Nelson M, et al. (2005) Comparison between household budget survey and 24-hour recall data in a nationally representative sample of Polish households. Public Health Nutr 8, 430-439.

163. Serra-Majem L, Ribas-Barba LF, Salvador GF, et al. (2007) Trends in energy and nutrient intake and risk of inadequate intakes in Catalonia, Spain (1992-2003). Public Health Nutr 10, 1354-1367.

164. Amcoff E, Edberg A, Enghardt BH, et al. (2012) Livsmedelsoch naringsintag bland vuxna $i$ Sverige (Food and Nutritional Intake among Adults in Sweden). Uppsala: Livsmedelsverket.

165. Public Health England \& Food Standards Agency (2014) National Diet and Nutrition Survey Results from Years 1, 2, 3 and 4 (combined) of the Rolling Programme (2008/ 2009 - 2011/2012). London: Public Health England.

166. Prynne CJ, McCarron A, Wadsworth ME, et al. (2010) Dietary fibre and phytate - a balancing act: results from three time points in a British Birth Cohort. Br J Nutr 103, 274-280.

167. United States Department of Agriculture (2014) What we eat in America. Data Tables. http://www.ars.usda.gov/ba/ bhnrc/fsrg (accessed October 2015).

168. IUNA (2015) Irish Universities Nutrition Alliance. http:// www.iuna.net/ (accessed October 2015).

169. Ocke MC, Bueno-de-Mesquita HB, Feskens EJ, et al. (1998) Adherence to the European Code Against Cancer in relation to long-term cancer mortality: intercohort comparisons from the Seven Countries Study. Nutr Cancer 30, $14-20$.

170. Australian Government Department of Health and Ageing (2007) 2007 Australian National Children's Nutrition and Physical Activity Survey : Volume 2: Nutrition Intakes. https://www.health.gov.au/internet/main/publishing.nsf/ Content/8F4516D5FAC0700ACA257BF0001E0109/\$File/ childrens-nut-phys-survey.pdf (accessed October 2015).

171. Liberona Y, Castillo O \& Rozowski J (2010) Suficiencia de la dieta y composición corporal en un grupo de niños de 11-14 años de dos clubes deportivos en Santiago de Chile (Dietary adequacy and body composition in a group of 11-14 year olds from two sports clubs in Santiago de Chile). Rev Chil Nutr 37, 145-154.

172. Hoppu U, Lehtisalo J, Tapanainen H, et al. (2010) Dietary habits and nutrient intake of Finnish adolescents. Public Health Nutr 13, 965-972.
173. Stahl A, Vohmann C, Richter A, et al. (2009) Changes in food and nutrient intake of 6- to 17-year-old Germans between the 1980s and 2006. Public Health Nutr 12, $1912-1923$.

174. Leclercq C, Piccinelli R, Arcella D, et al. (2004) Food consumption and nutrient intake in a sample of Italian secondary school students: results from the INRAN-RM-2001 food survey. Int J Food Sci Nutr 55, 265-277.

175. Overby NC \& Ungkost LF-A (2002) Landsomfattende kostholdundersokelse blant elever i 4 -og 8. klasse $i$ Norge (Nationwide Dietary Survey Among Pupils in 4th and 8th Grade in Norway). Oslo: Solse-og helsedirektoratet.

176. Kovalskys I, Indart P, Paz M, et al. (2013) Food intake and anthropometric evaluation in school-aged children of Buenos Aires. Arch Argent Pediatr 111, 9-14.

177. Lin Y, Bolca S, Vandevijvere S, et al. (2011) Dietary sources of fiber intake and its association with socio-economic factors among Flemish preschool children. Int J Mol Sci 12, $1836-1853$.

178. Kynde I, Johnsen NF, Wedderkopp N, et al. (2010) Intake of total dietary sugar and fibre is associated with insulin resistance among Danish 8-10-and 14-16-year-old girls but not boys. European Youth Heart Studies I and II. Public Health Nutr 13, 1669-1674.

179. Kyttälä P, Erkkola M, Kronberg-Kippilä C, et al. (2010) Food consumption and nutrient intake in Finnish 1-6-yearold children. Public Health Nutr 13, 947-956.

180. Buyken AE, Cheng G, Günther AL, et al. (2008) Relation of dietary glycemic index, glycemic load, added sugar intake, or fiber intake to the development of body composition between ages 2 and 7 y. Am J Clin Nutr 88, $755-762$.

181. Grammatikopoulou MG, Daskalou E, Hatzopoulou M, et al. (2009) Comparing diet composition and growth of children living in two limitary Greek islands (Samos and Corfu). Public Health Nutr 12, 1284-1289.

182. Enghardt Barbieri H, Pearson M \& Becker W (2006) Riksmaten - barn 2003: livsmedels- och naringsintag bland barn i Sverige (National food - Children 2003: Food and nutrient intake among children in Sweden). Uppsala: Livsmedelsverket.

183. Zhou SJ, Gibson RA, Gibson RS, et al. (2012) Nutrient intakes and status of preschool children in Adelaide, South Australia. Med J Aust 196, 696-700.

184. Bosscher D, Van Caillie-Bertrand M \& Deelstra H (2002) Daily dietary fibre intake of children, 2 to 3 years of age, living in Antwerp, Belgium. Nutr Res 22, 1401-1411.

185. Gubbels JS, Raaijmakers LG, Gerards SM, et al. (2014) Dietary intake by Dutch 1- to 3-year-old children at childcare and at home. Nutrients 6, 304-318.

186. Lennox A, Sommerville J, Ong K, et al. (2014) Diet and Nutrition Survey of Infants and Young Children, 2011. London: Health England.

187. O'Neil CE, Zanovec M, Cho SS, et al. (2010) Whole grain and fiber consumption are associated with lower body weight measures in US adults: National Health and Nutrition Examination Survey 1999-2004. Nutr Res 30, 815-822.

188. Reicks M, Jonnalagadda S, Albertson AM, et al. (2014) Total dietary fiber intakes in the US population are related to whole grain consumption: results from the National Health and Nutrition Examination Survey 2009 to 2010. Nutr Res 34, 226-234.

189. Royo-Bordonada MA, Gorgojo L, De Oya M, et al. (2003) Food sources of nutrients in the diet of Spanish children: the Four Provinces Study. BrJ Nutr 89, 105-114. 
190. Keast DR, Nicklas TA \& O'Neil CE (2010) Snacking is associated with reduced risk of overweight and reduced abdominal obesity in adolescents: National Health and Nutrition Examination Survey (NHANES) 1999-2004. Am J Clin Nutr 92, 428-435.

191. Murphy MM, Douglass JS \& Birkett A (2008) Resistant starch intakes in the United States. J Am Diet Assoc 108, 67-78.

192. Baghurst PA, Record SJ \& Baghurst K (1996) Dietary Fibre, Non-Starch Polysaccharides and Resistant Starch: A Review. North Sydney: Australian Institute of Food Science and Technology.

193. Brighenti F, Casiraghi MC \& Baggio C (1998) Resistant starch in the Italian diet. Br J Nutr 80, 333-341.

194. Chen L, Liu R, Qin C, et al. (2010) Sources and intake of resistant starch in the Chinese diet. Asia Pac J Clin Nutr 19, 274-282.
195. European Commission (2012) EU Register of nutrition and health claims made on foods. https://ec.europa.eu/food/ safety/labelling_nutrition/claims_en (accessed October 2015).

196. Agence Nationale de Sécurité Sanitaire de l'Alimentation, de l'Environnement et du Travail (ANSES) (2016) Equilibre entre les macronutriments - Recommandations d'apport en fibres (Equilibrium between Macronutrients - Recommendations for Dietary Fibre Intake) - Saisine n 2012-SA-0186 - 37 pp. Maisons-Alfort, France: ANSES.

197. Bar-L'Helgouac'h C, Barron C \& Saulnier L (2013) Comparaison des méthodes AOAC 985.29, 2001.03 et 2009.01 pour le dosage des fibres alimentaires dans les produits céréaliers à base de blé (Comparison of AOAC $985.29,2001.03$ et 2009.01 methods for the analysis of dietary fibres in cereal products based on wheat). Industries des Céréales 185, 13-20. 